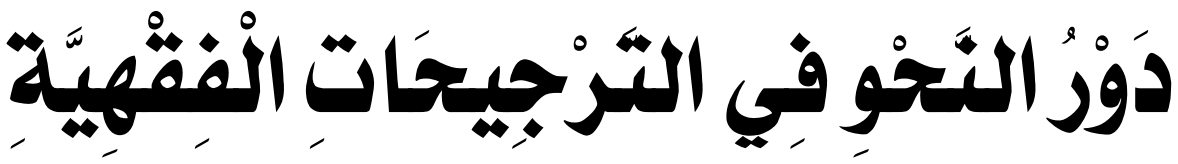

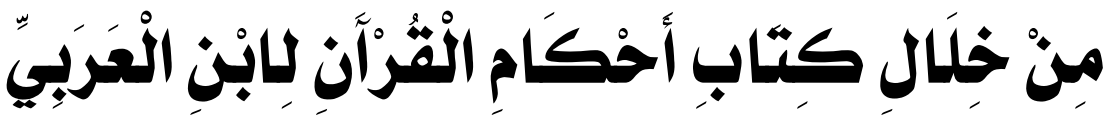

\section{و . .}

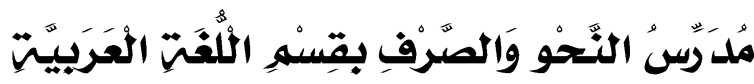

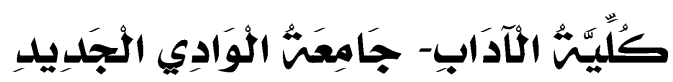




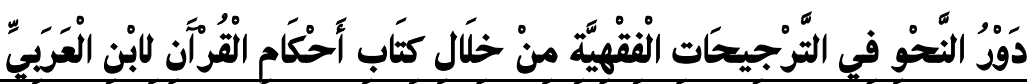

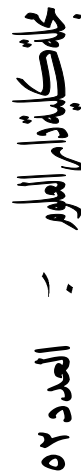




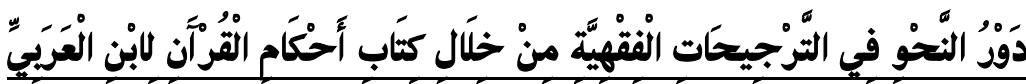

\section{الْمُلَخُصن}

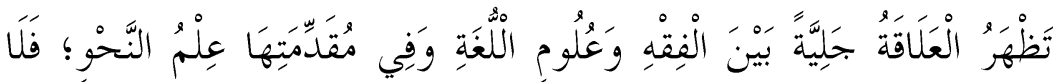

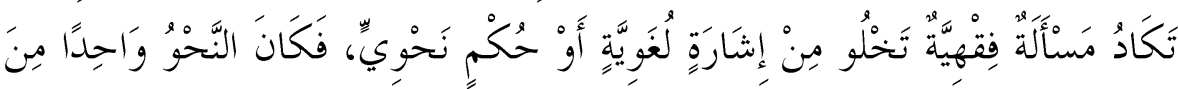

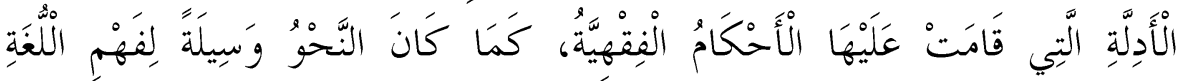

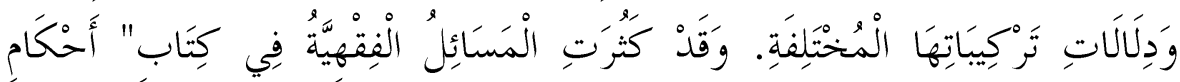

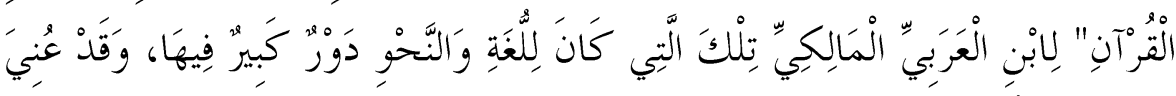

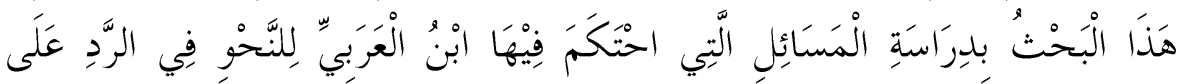

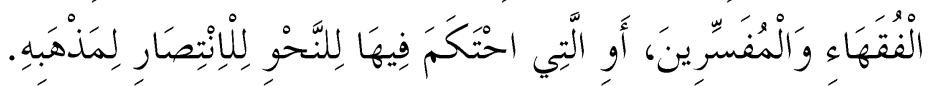

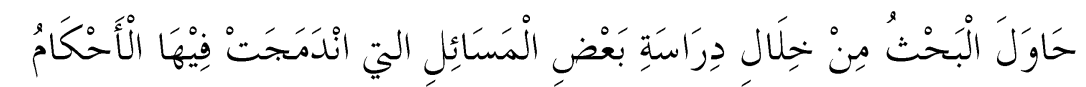

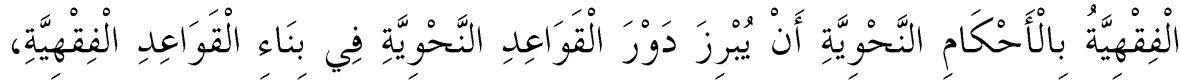

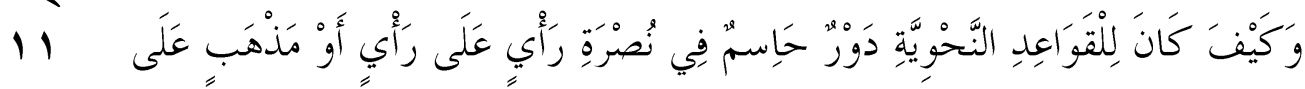

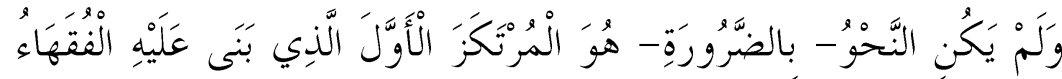

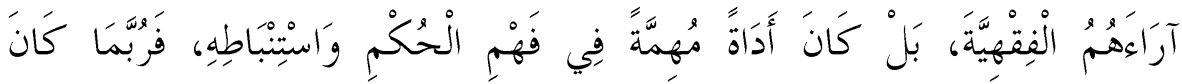

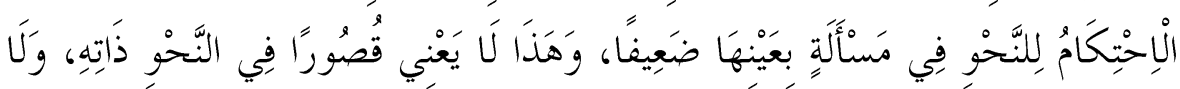

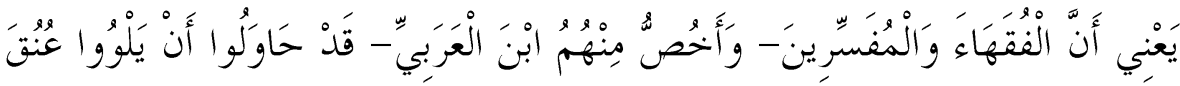

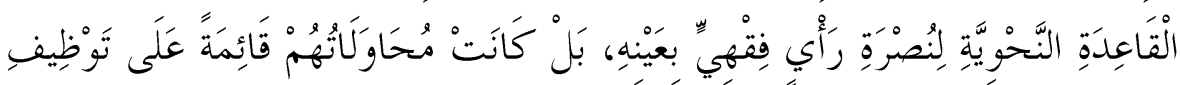

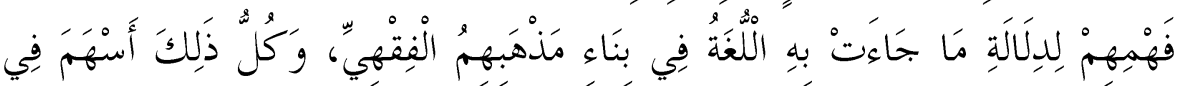

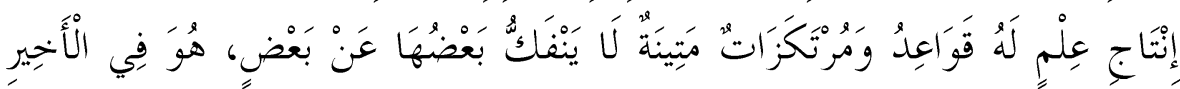

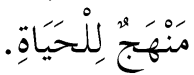




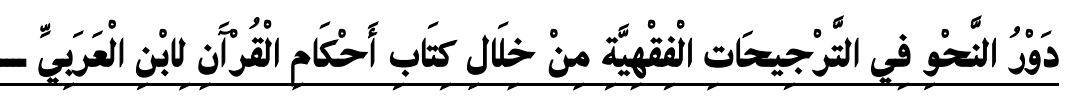

\section{Abstract}

There is an evident relationship between the science of Fiqh ( jurisprudence) and the science of grammer. There is hardly a topic in Fiqh that has no linguistic significance or a grammatical rule.So, it can be said that grammer has always been a means upon which topics in Fiqh are based.Moreover, grammer has always been a means to interpret the language and to understand its different constructions. There are many Fiqh topics in Ebn El Araby Elmaleky book" Ahkam al Qur'an", that can not be understood away from the science of linguistics and grammer, in other words, these topics can not be understood away from its grammatical context. So,the purpose of this research is to study some topics in Fiqh which in Ebn El Araby used the science of grammer to clarify and to prove his opinion compared with jurists. This study attempted to prove, through a nalyzing some of topics, the important role of the grammatical rules in constructing the basics of the rules of Fiqh( Jurisprudence).

The study always attempted to indicate how these grammatical rules approved and validated, strictly, the opinions of a specific doctrine and, at the same time, denunciated others. This doesn't mean that grammer has been the first pillar on which jurists' opinions are based. But it has been an importand tool that has been used to understand the topic or the problem. And it may be, some times, wrong to use a specific grammatical rule to understand a specific topic. This doesn't mean that there is some sort of inadequacy in the science of grammer,or that jurists and interpreters, with a refrence to Ibn El araby here, have tried to misuse grammer to prove or highlight a specific opinion in a topic in Fiqh. In fact, they tried to avail and utilize their own understanding of the language to construct their docrince. The result of this was a science( Islamic Fiqh) that has its strong pillars and basics which make it away to followed in life.
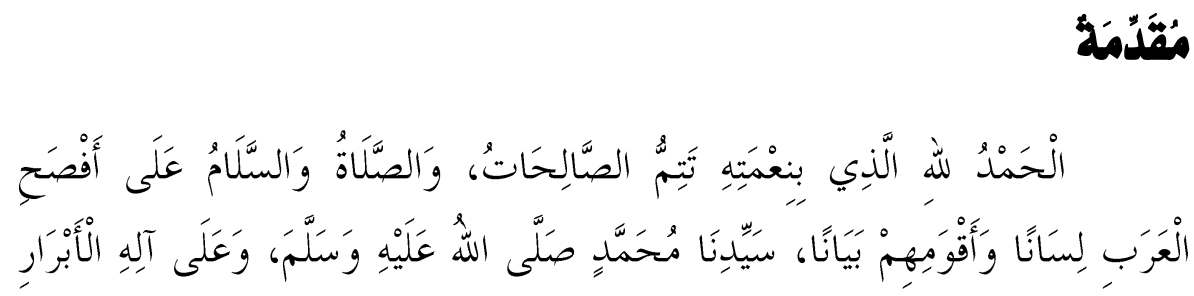


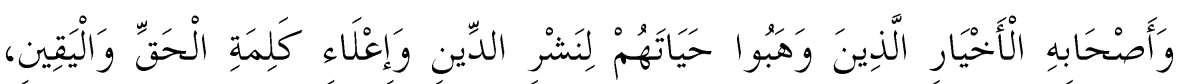
وَبَعْدُ:

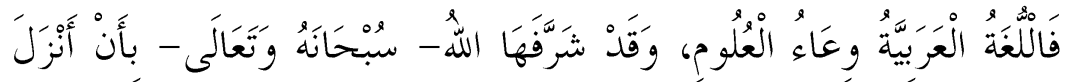

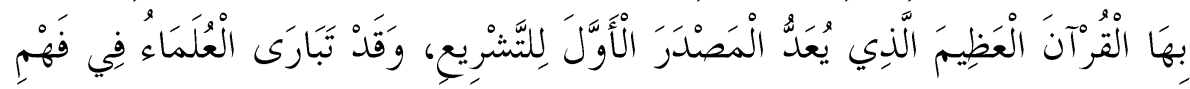

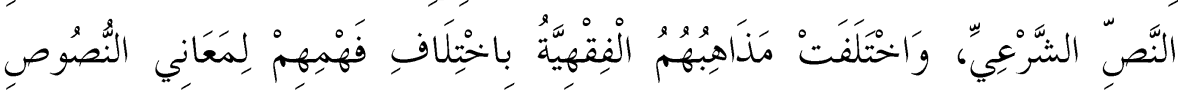

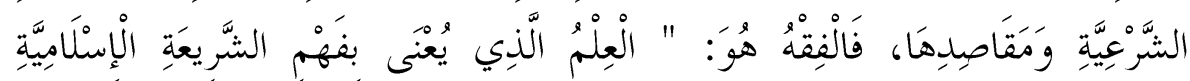

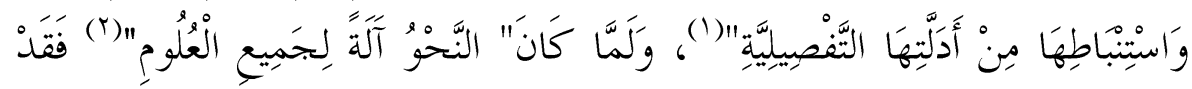

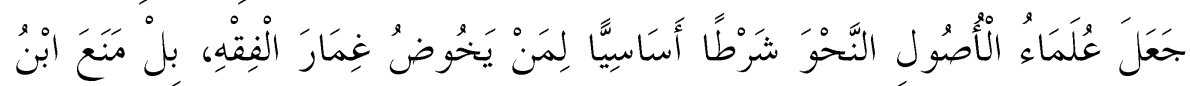

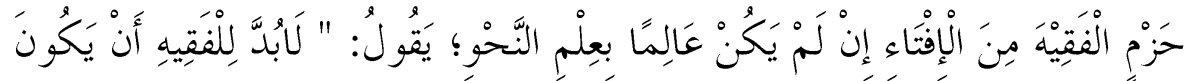

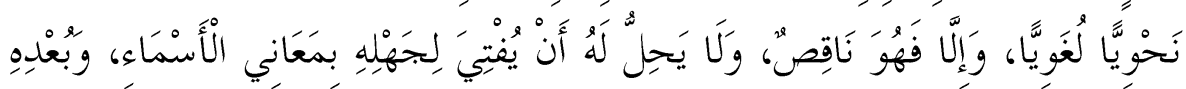

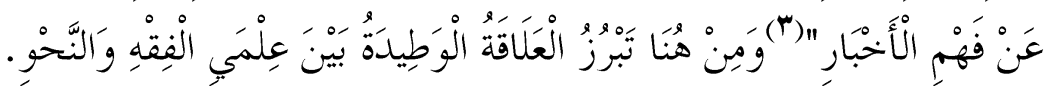

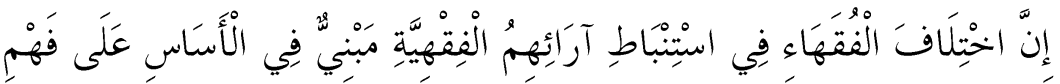

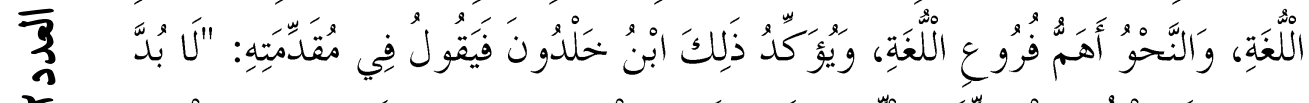

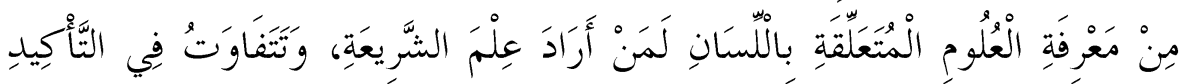

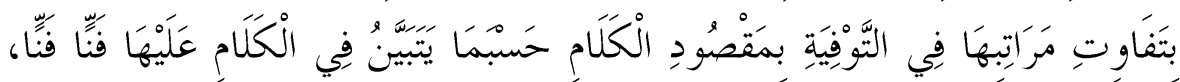

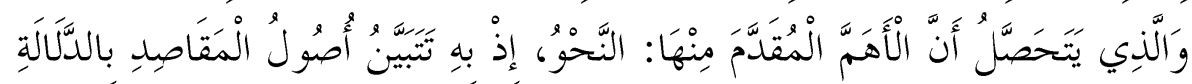

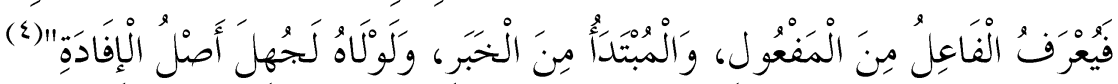

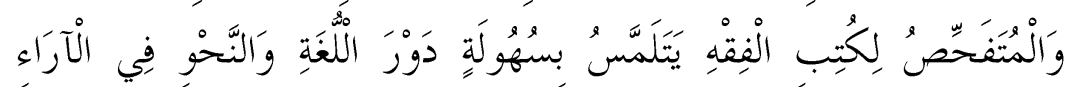

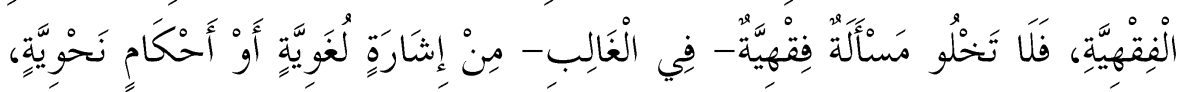

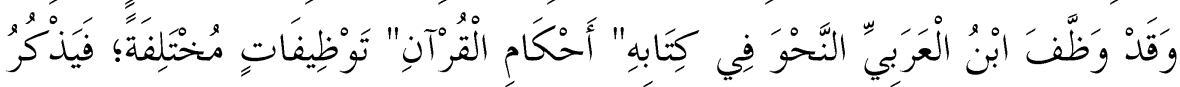

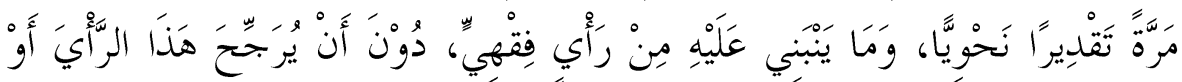

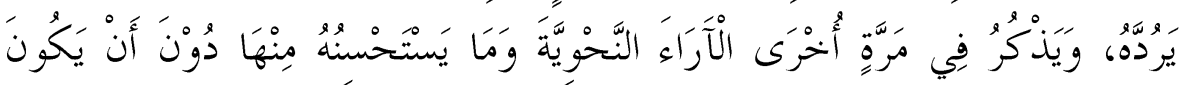




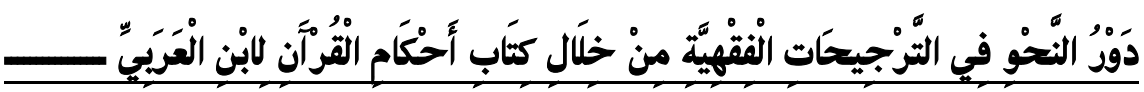

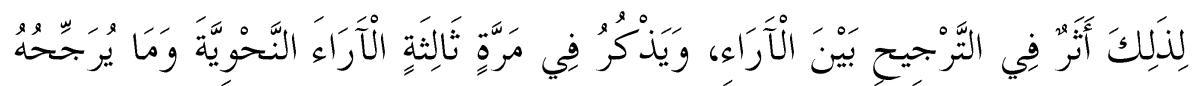

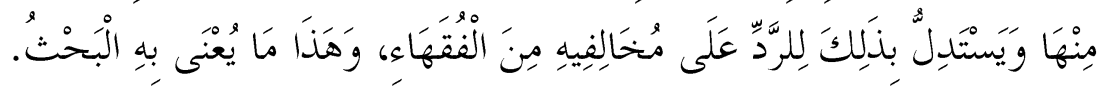

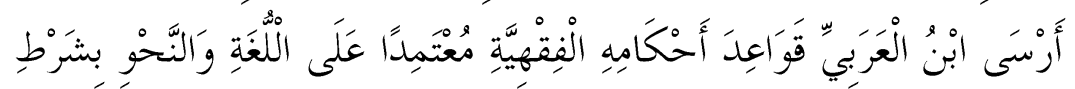

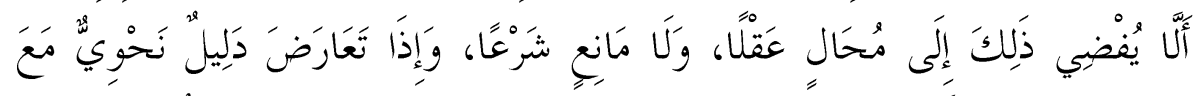

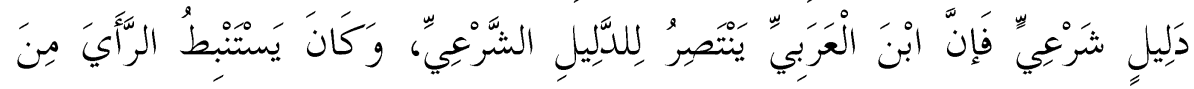

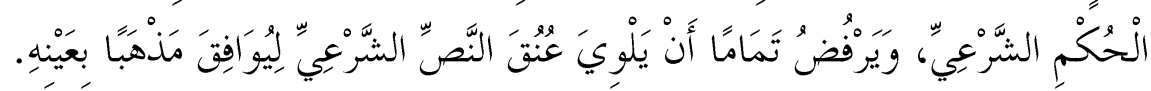

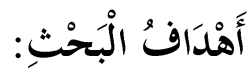

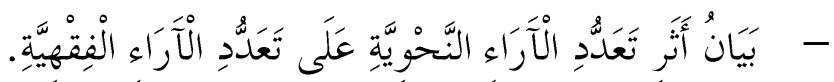

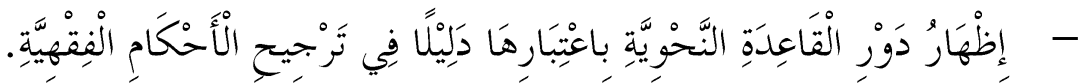

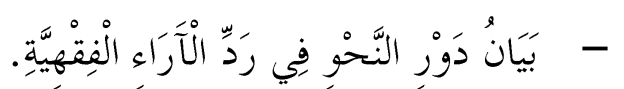

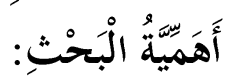

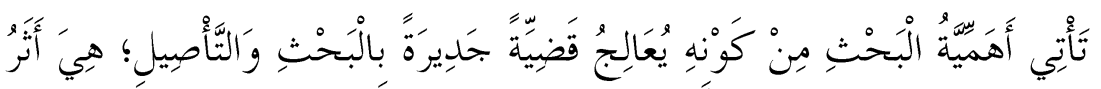

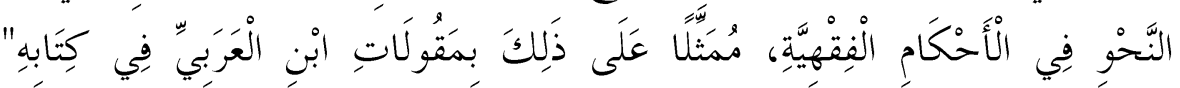

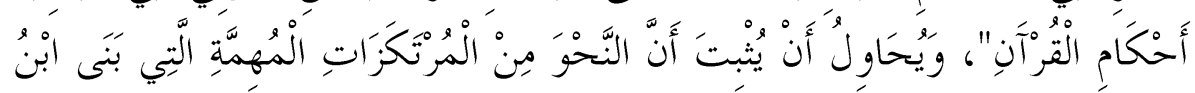

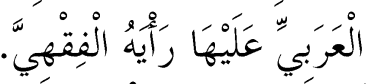

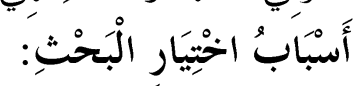

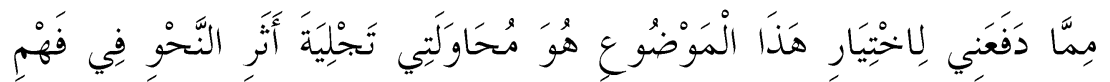

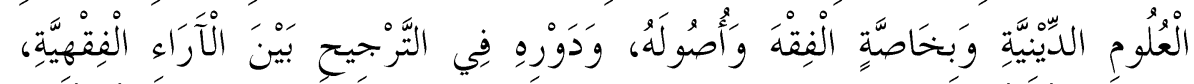

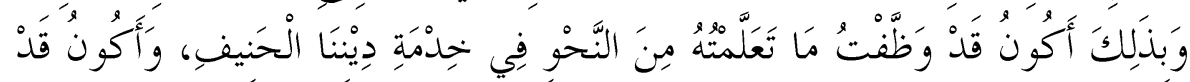

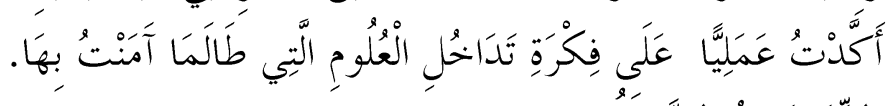
الدِّرَاسَاتُ السَّابقَةُّ:

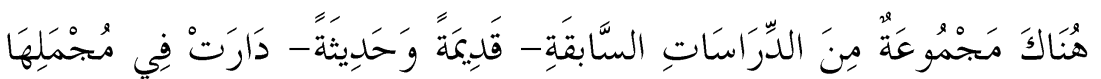

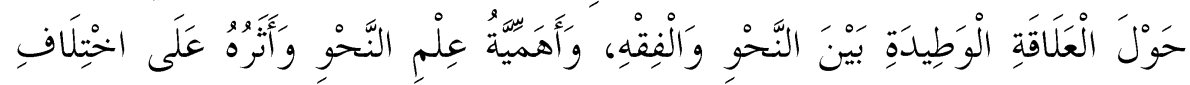

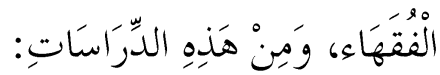




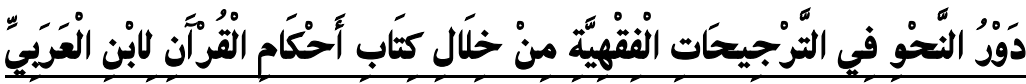

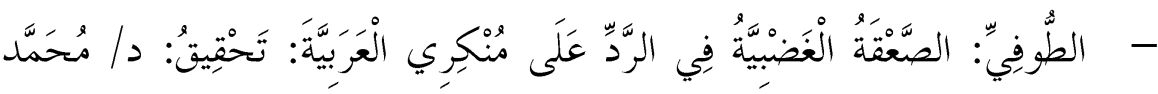

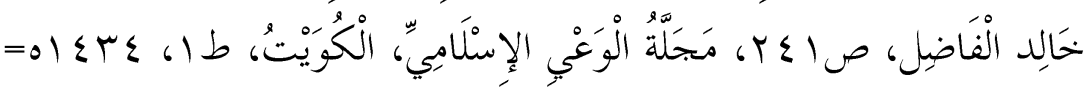

$$
\cdot \operatorname{st}
$$

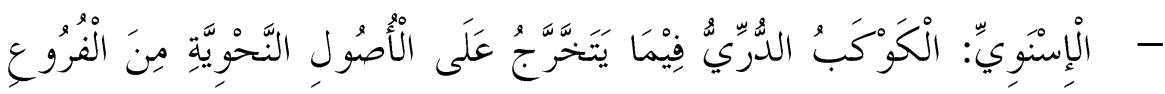

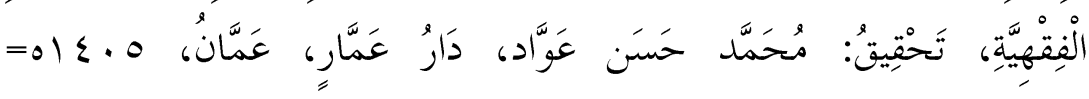

$$
\text { . } 1910
$$

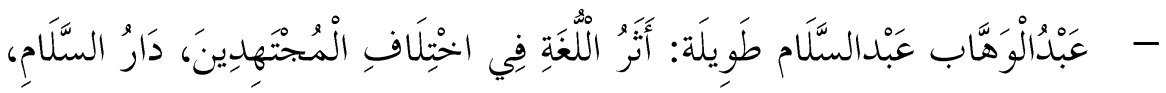

$$
\cdot P r \cdot .=01 \leqslant r \cdot 6 r b
$$

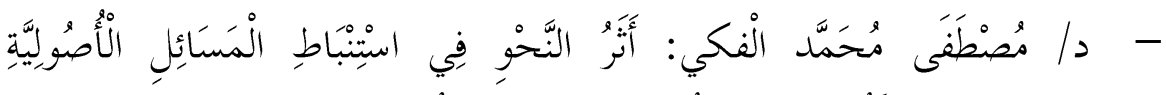

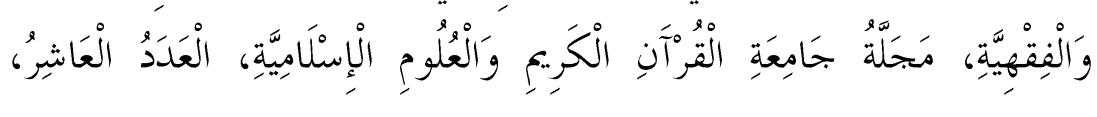

$$
\cdot p r \cdot 0=1 \leqslant r\}
$$

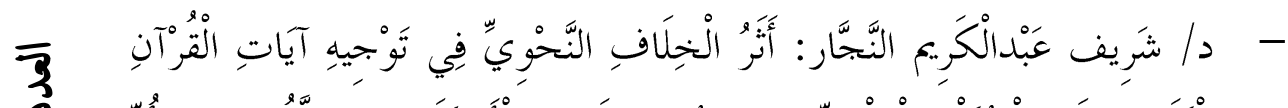

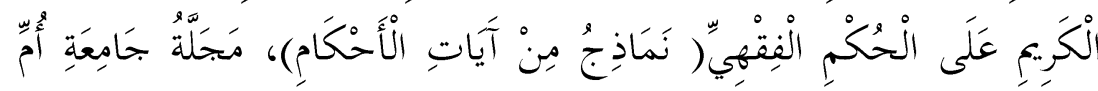

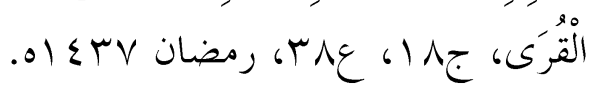

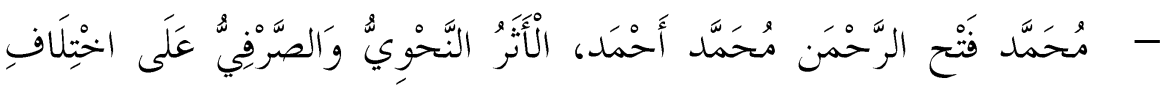

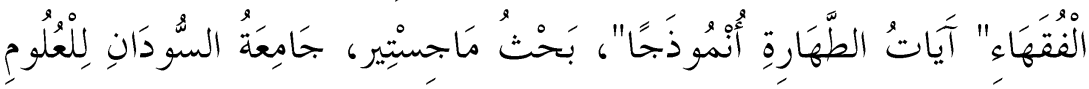

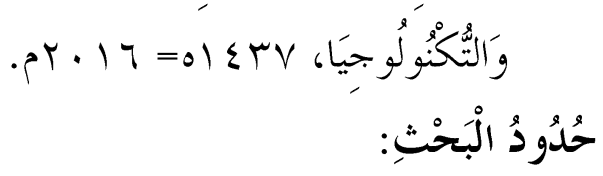

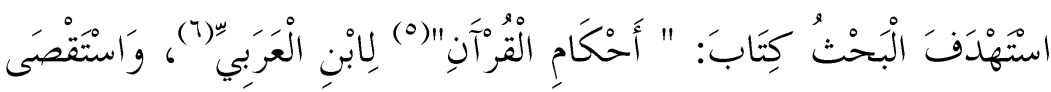

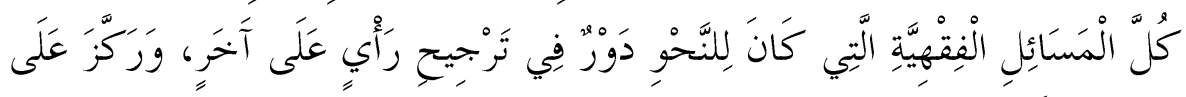

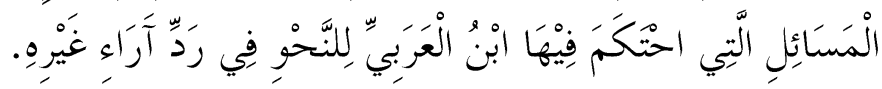




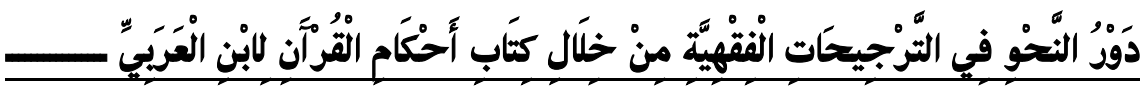

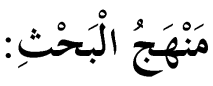

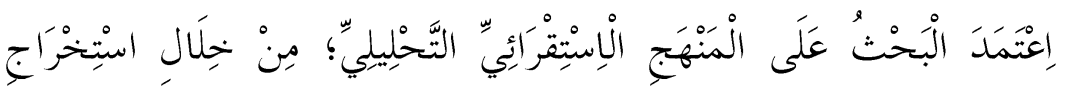

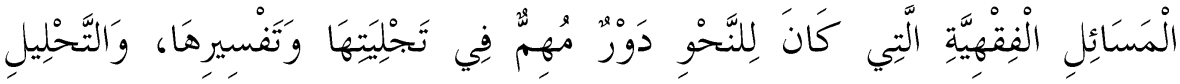

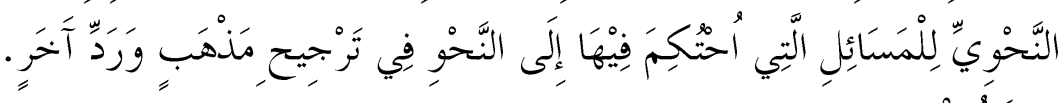

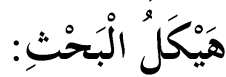

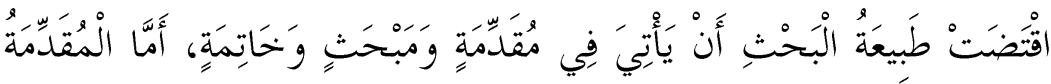

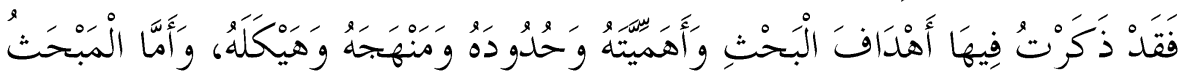

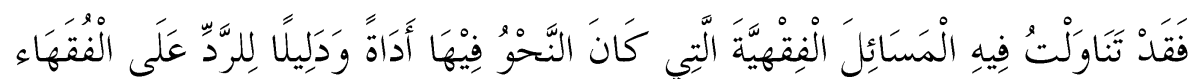

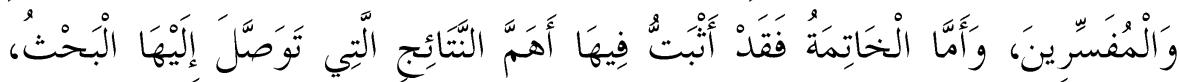

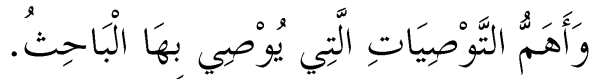

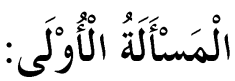

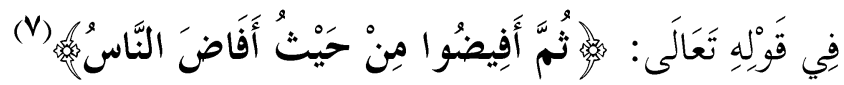
喜

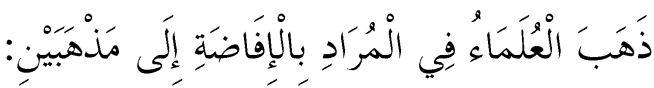

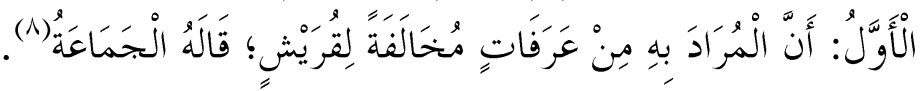

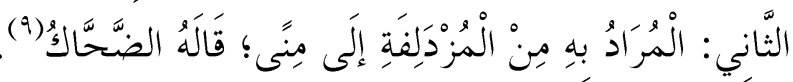

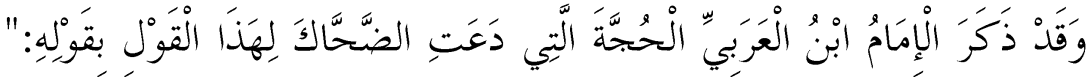

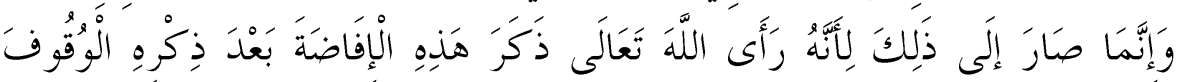

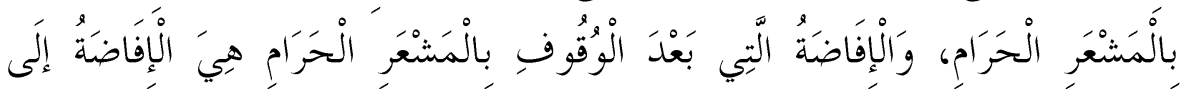
مَنَّى") (1.) (1)

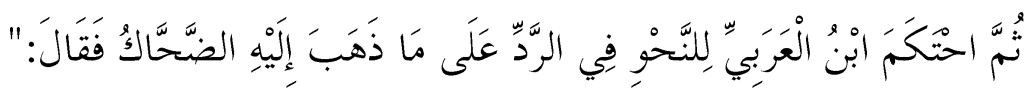

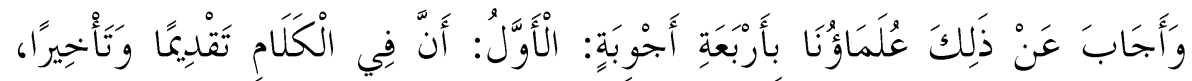

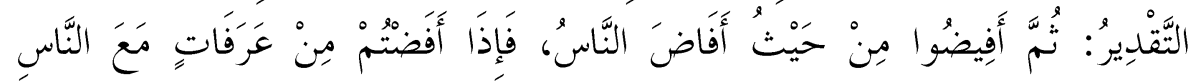

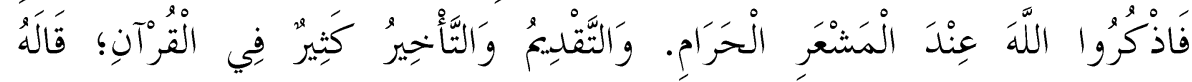

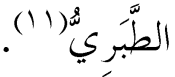




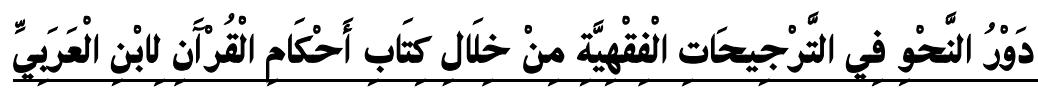

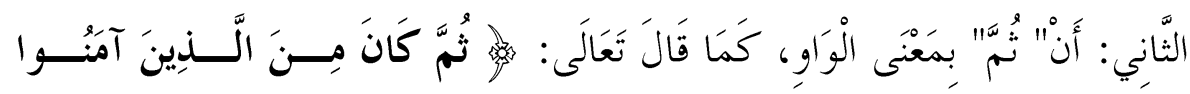

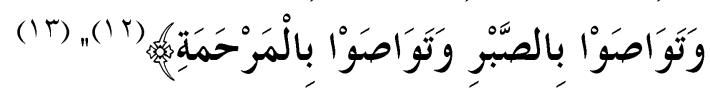

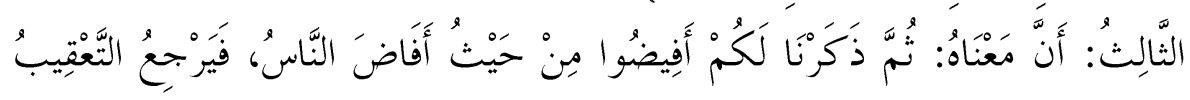

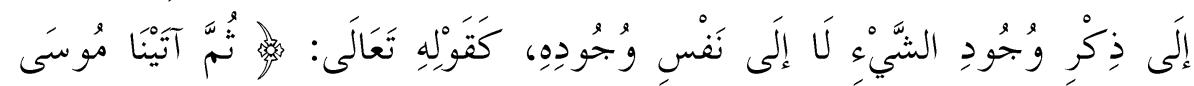

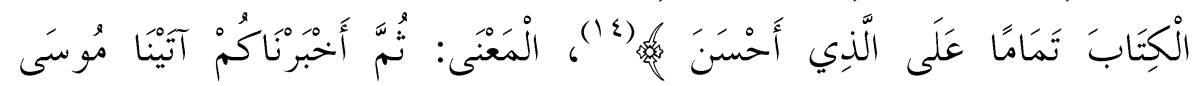

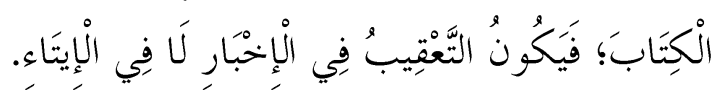

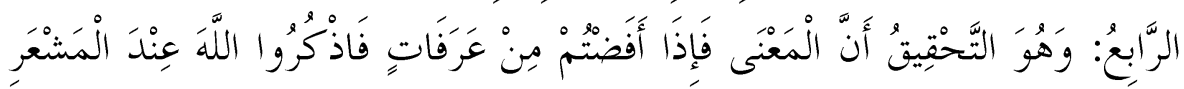

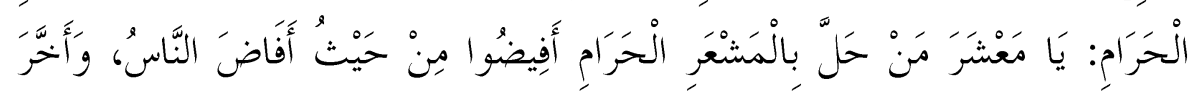

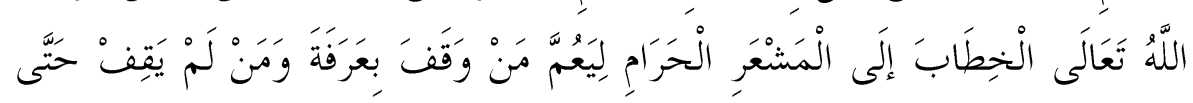

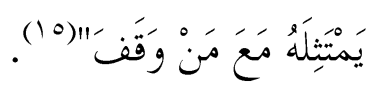

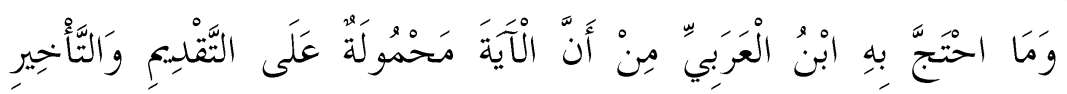

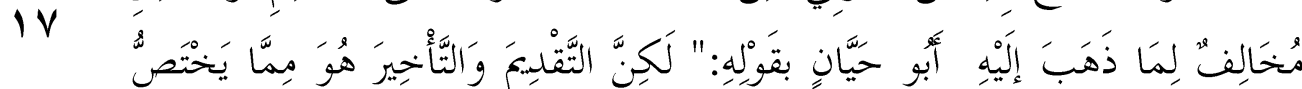

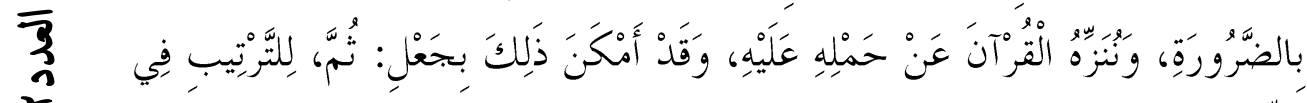

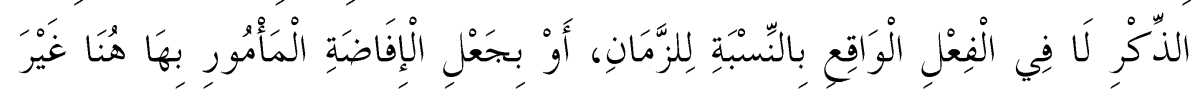

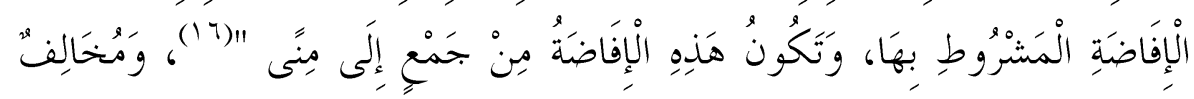

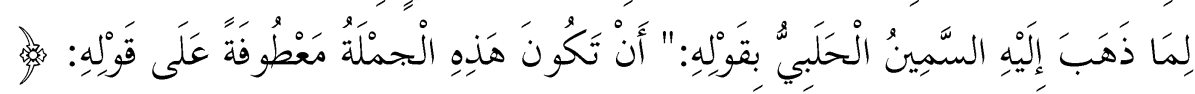

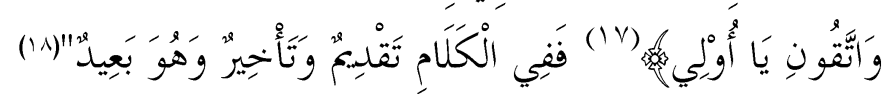

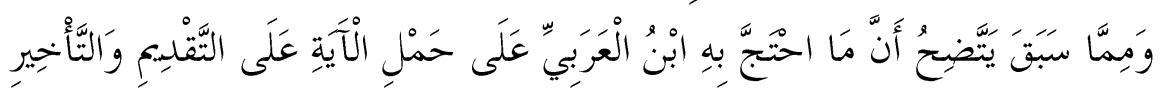
فِيِهِ نَظَرْ.

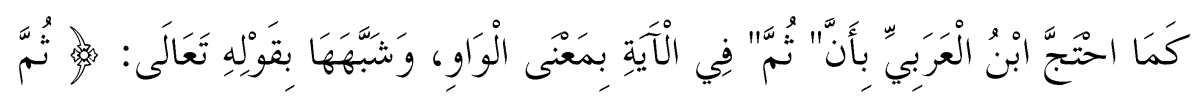

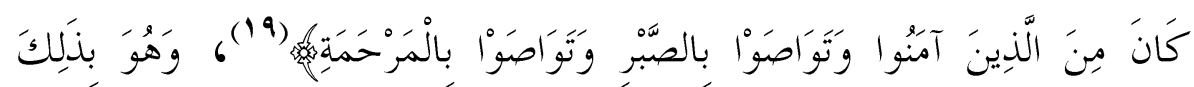

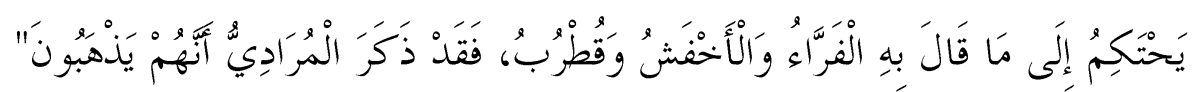




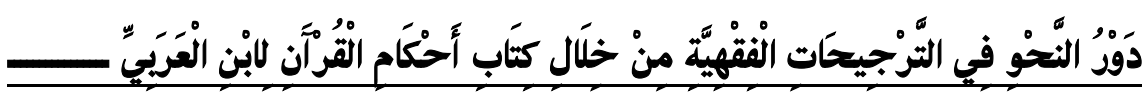

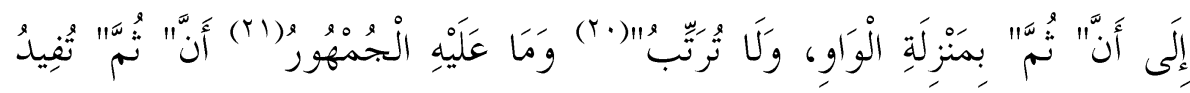

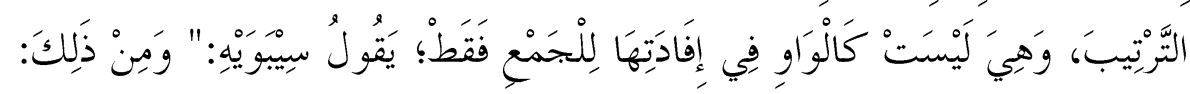

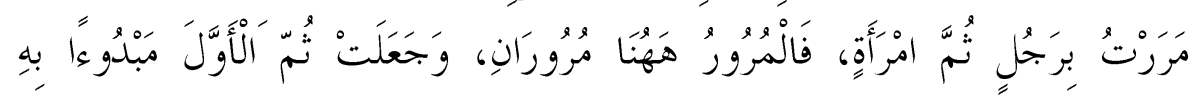

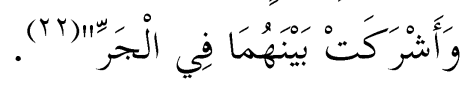

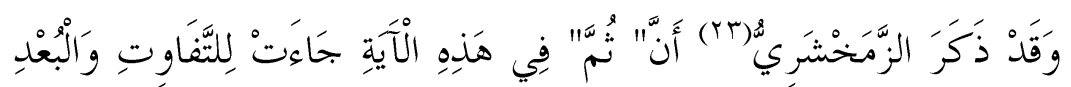

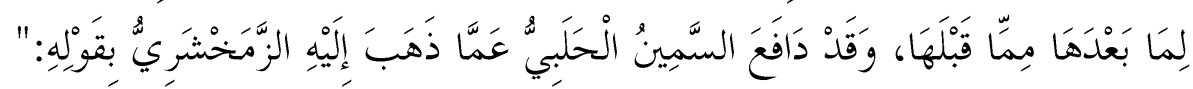

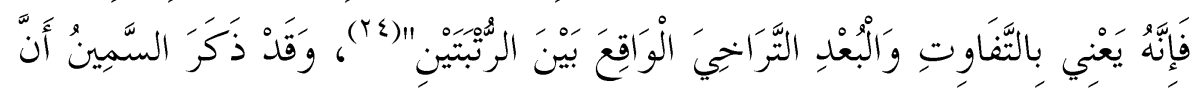

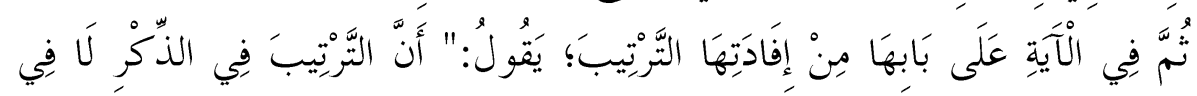

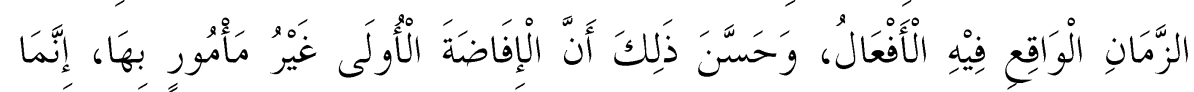

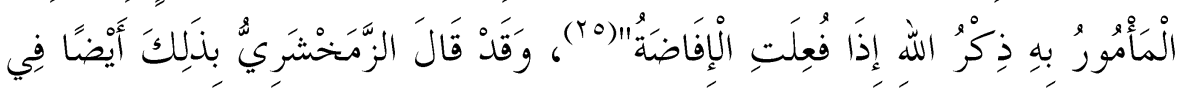

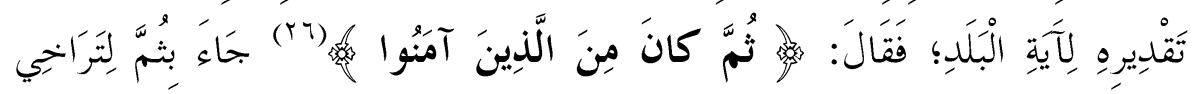

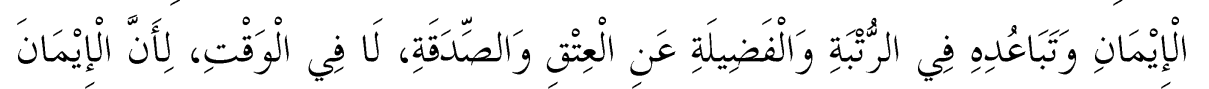

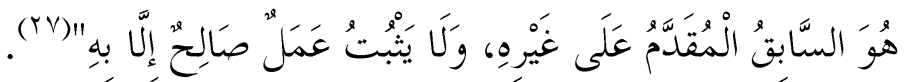

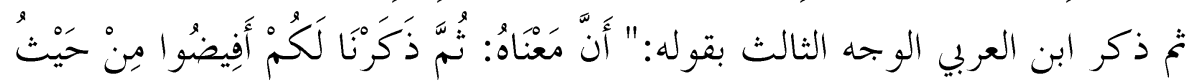

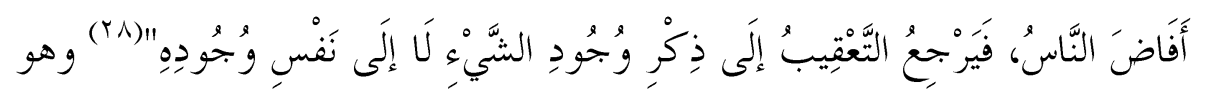
$\overline{3}$
3
2
0

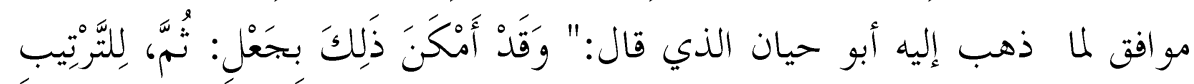

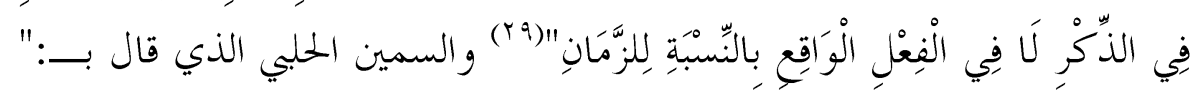

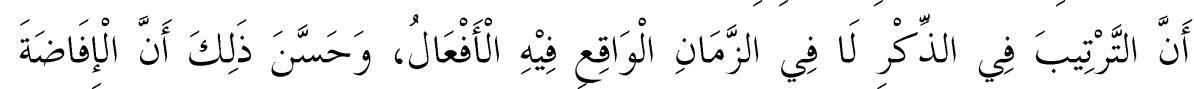

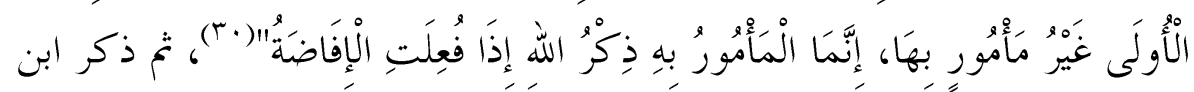
العربي الوجه الرابع الذي هو وجهه معنوي يشرح فيه مقصود الآية .

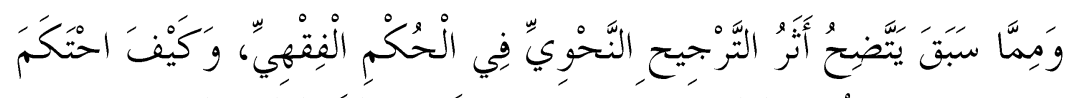

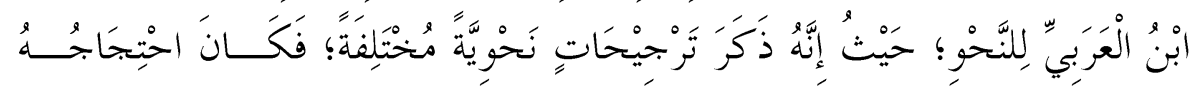

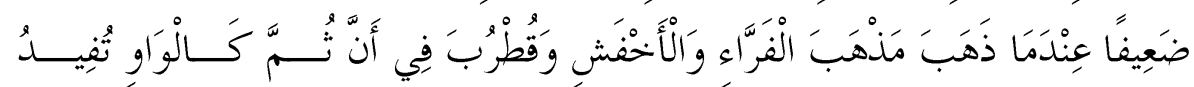




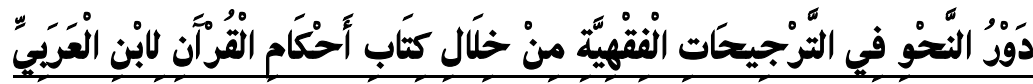

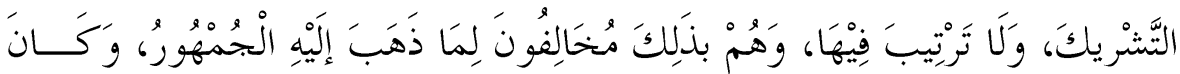

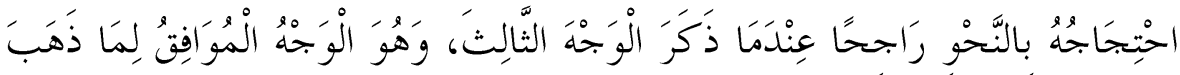

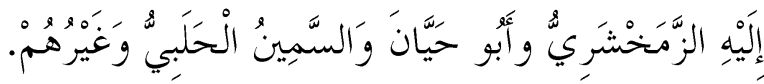

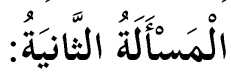

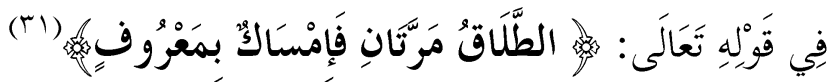

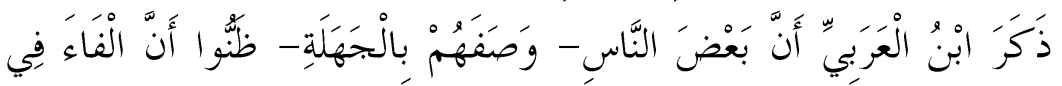

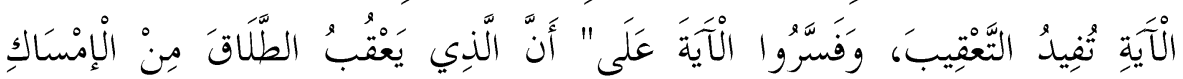

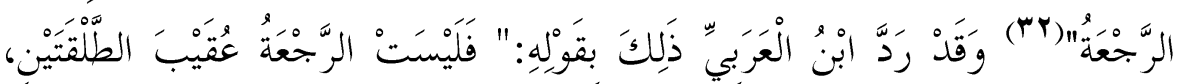

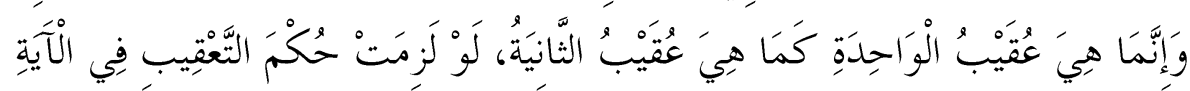

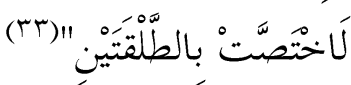
19

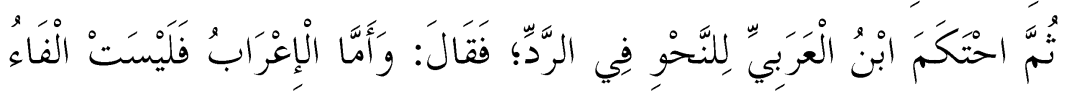

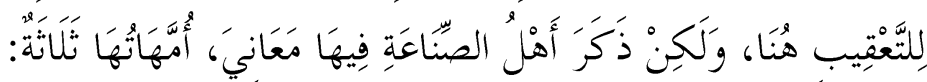

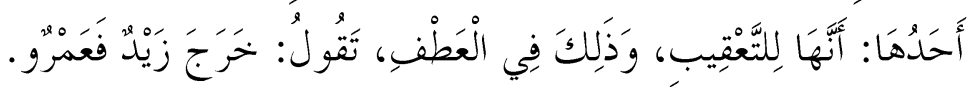

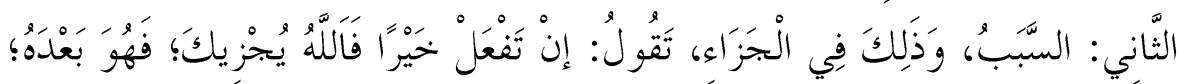

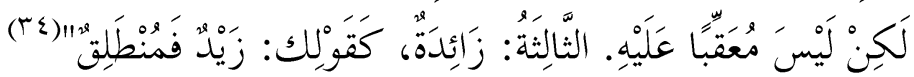

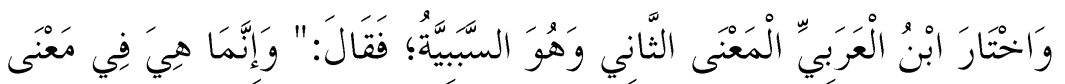

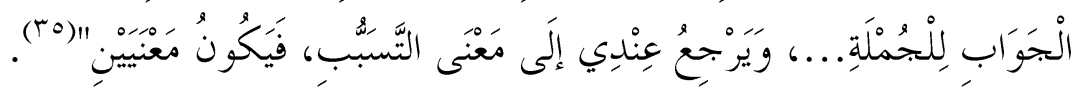

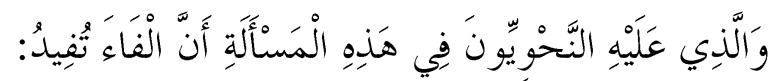

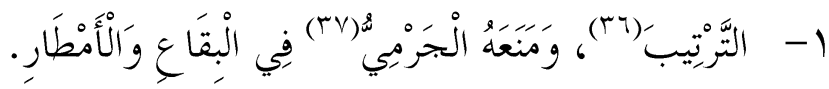

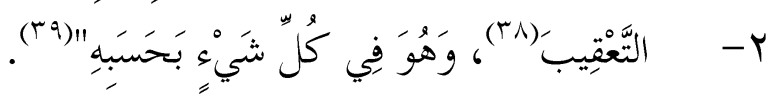

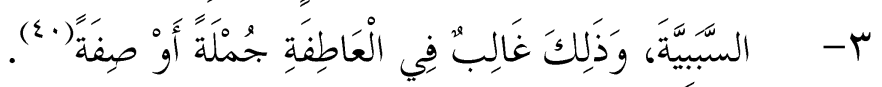




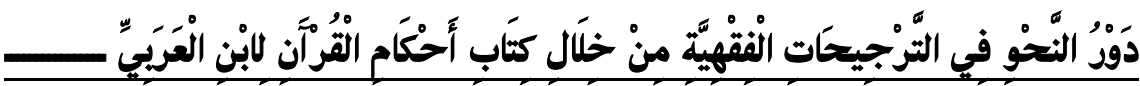

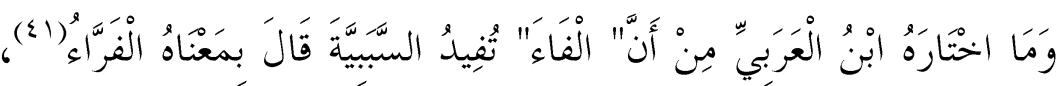

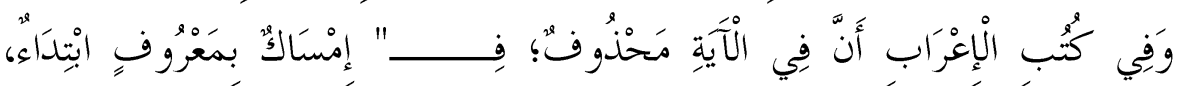

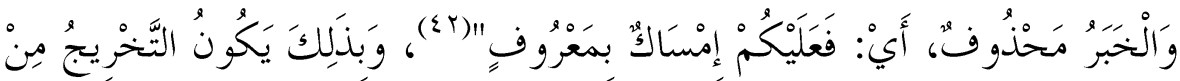

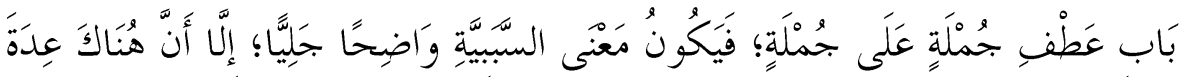

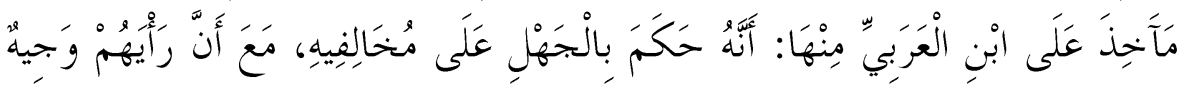

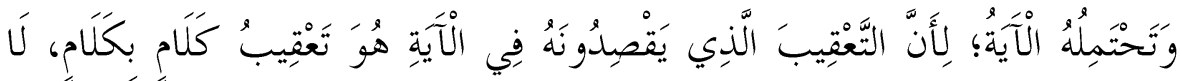

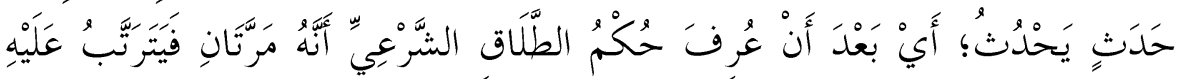

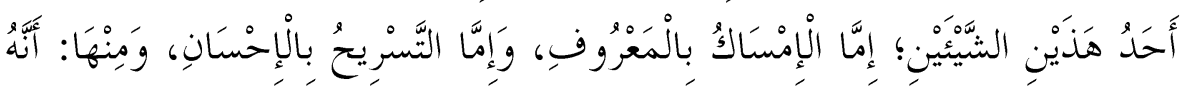

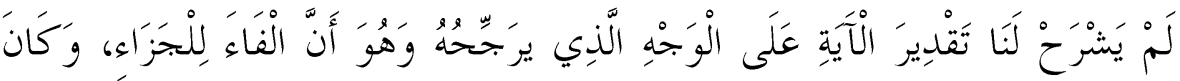

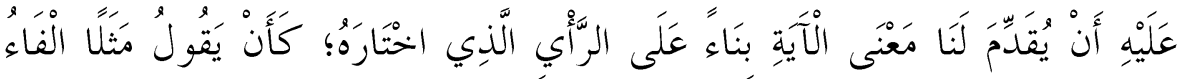

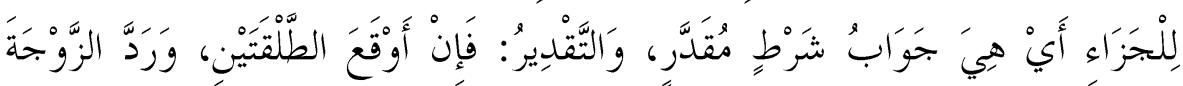

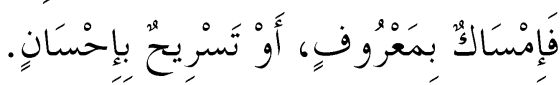

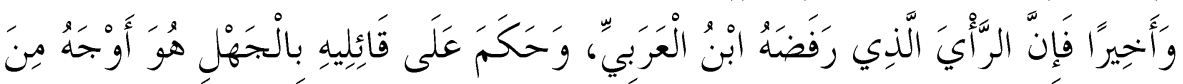

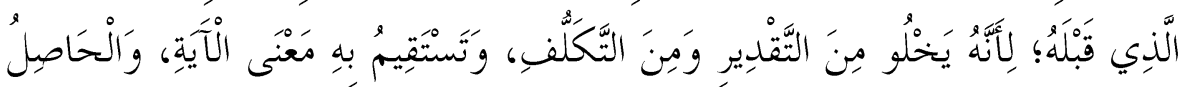

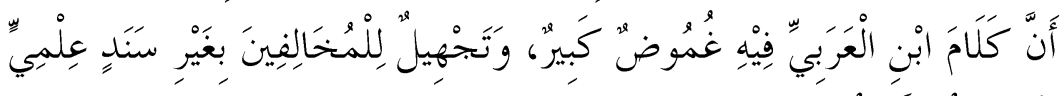

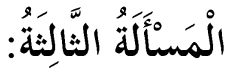

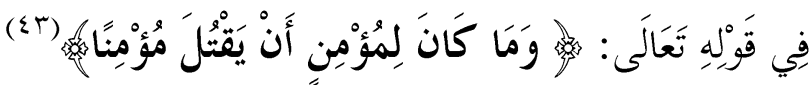

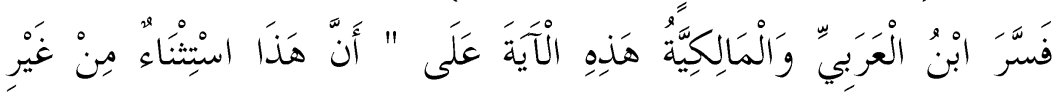

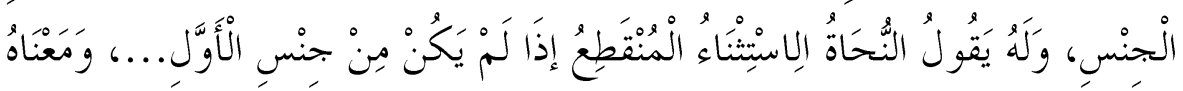

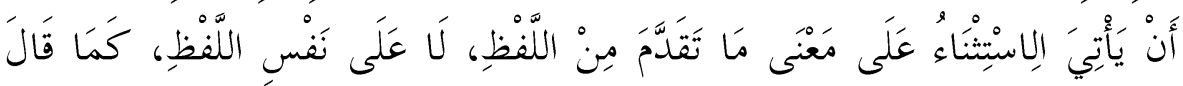

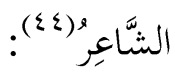

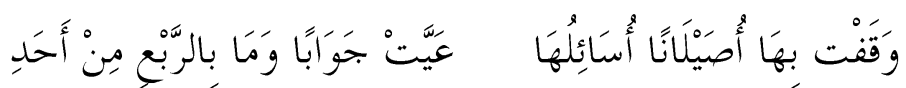

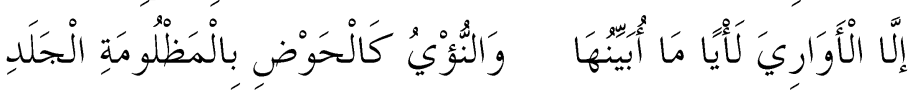




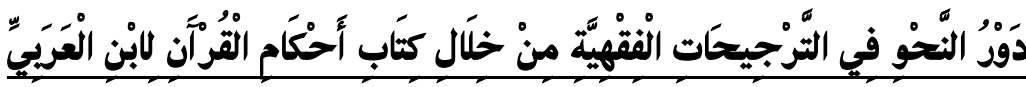

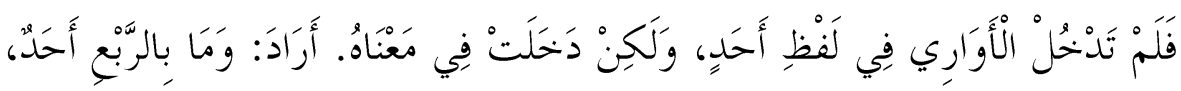

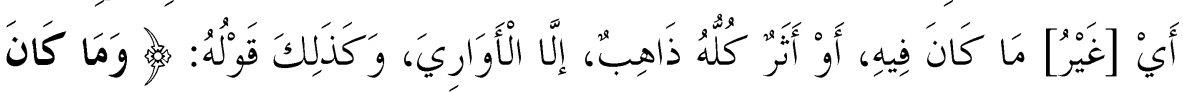

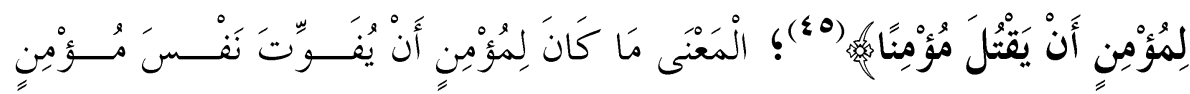

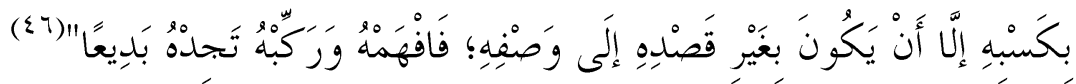

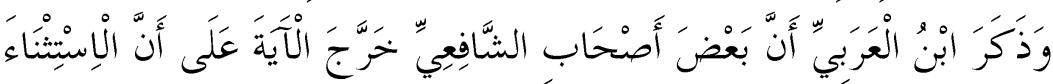

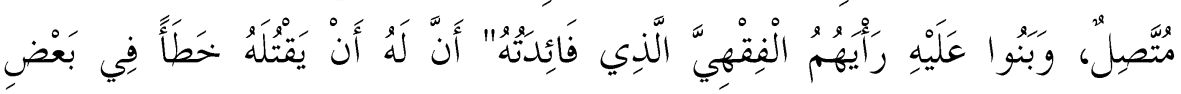

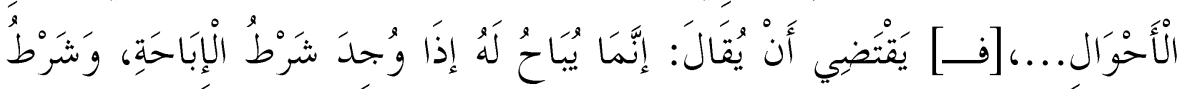

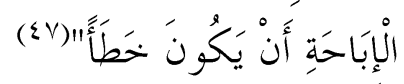

贻

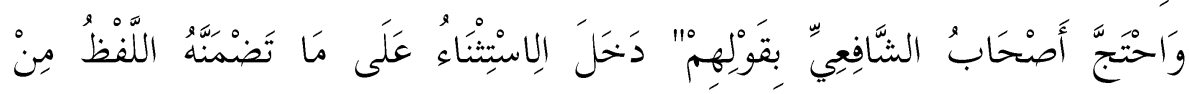

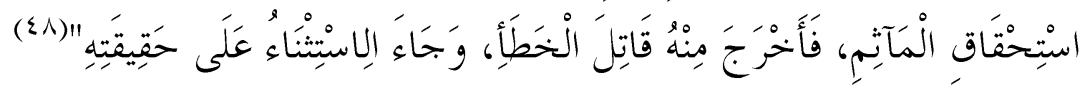

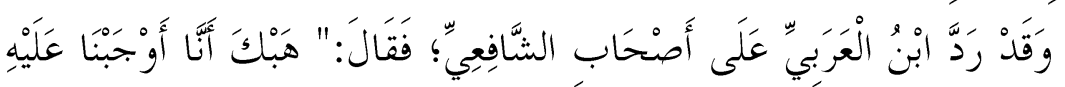

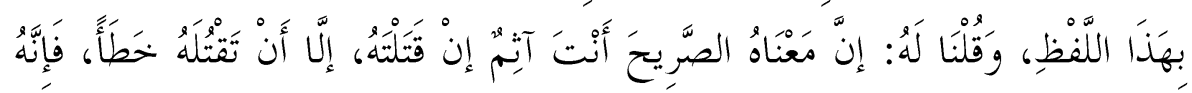

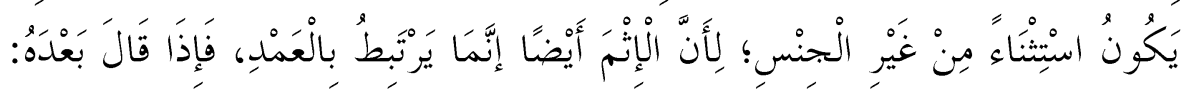

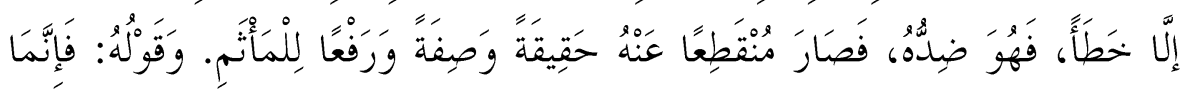

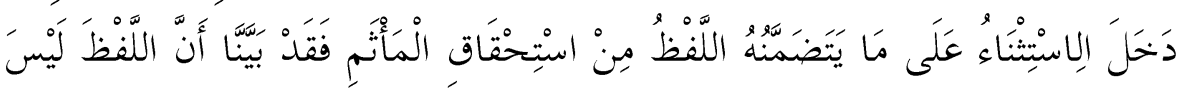

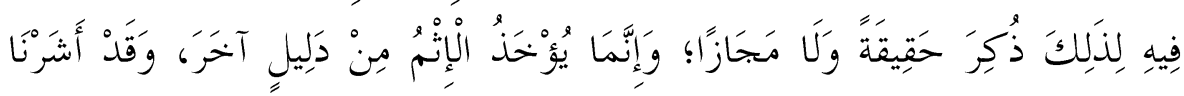

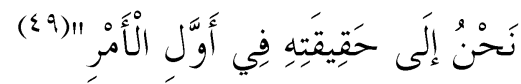

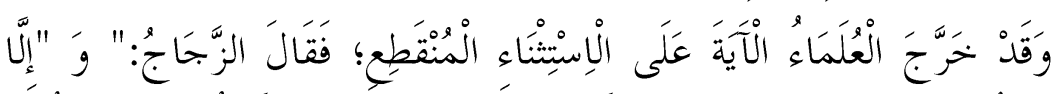

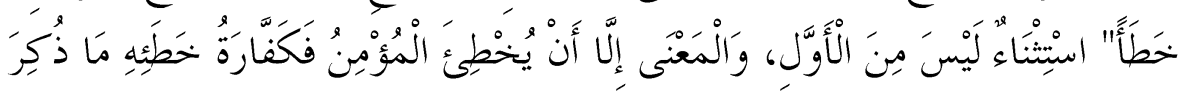

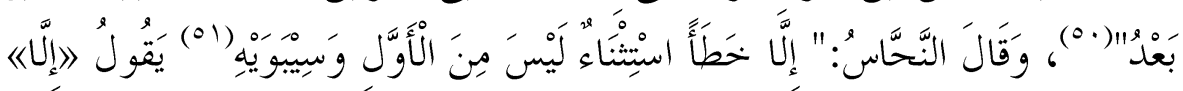

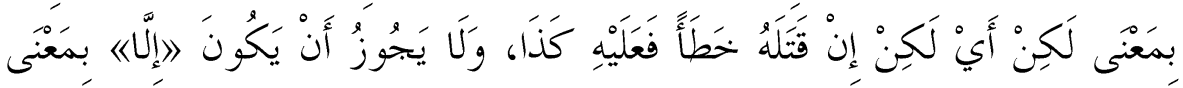

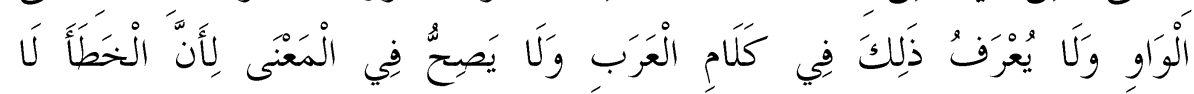

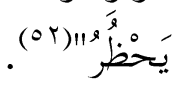




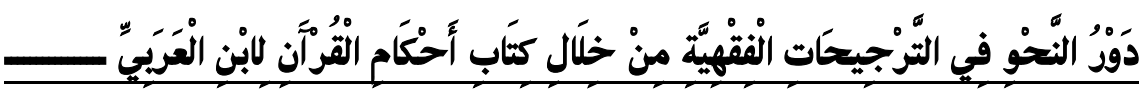

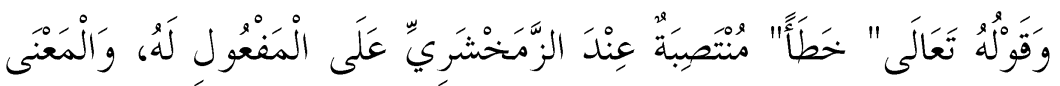

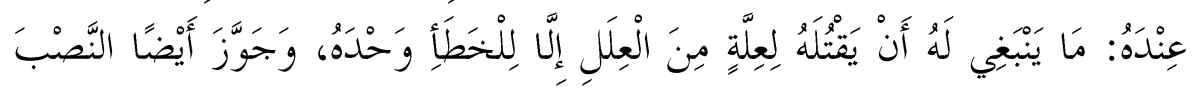

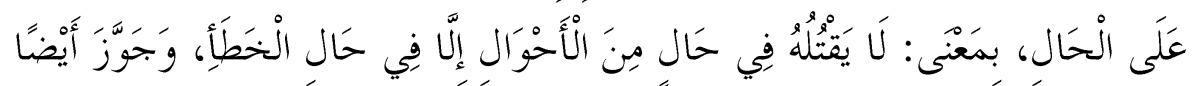

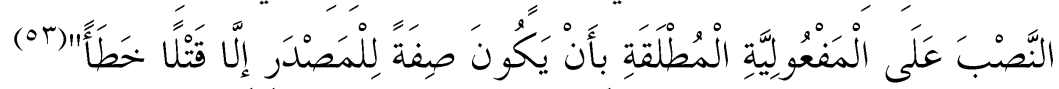

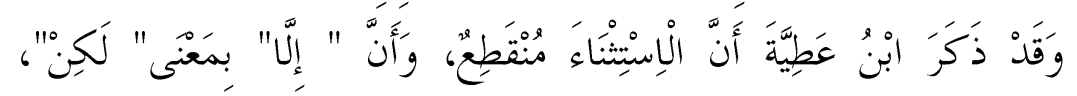

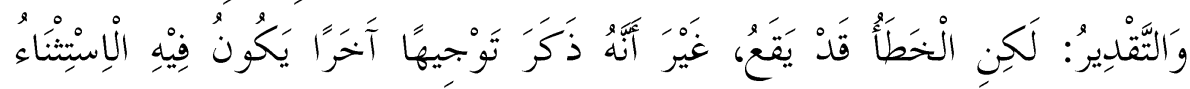

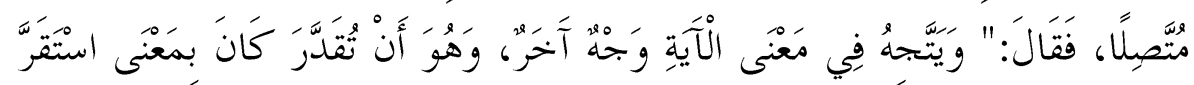

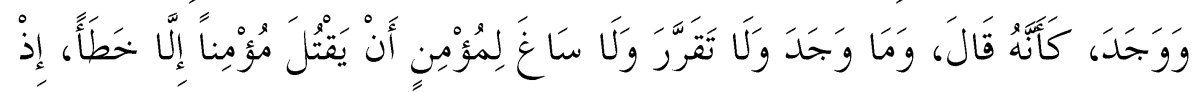

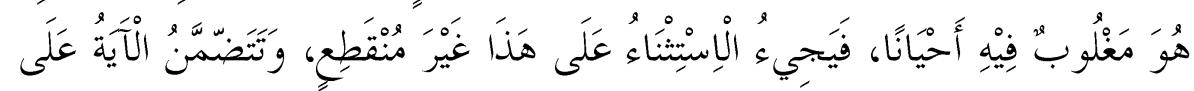

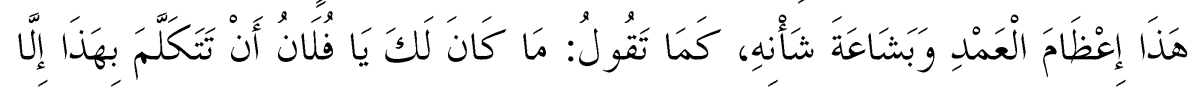

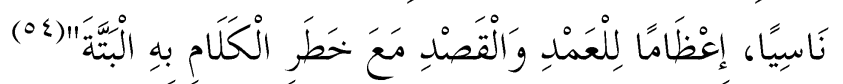

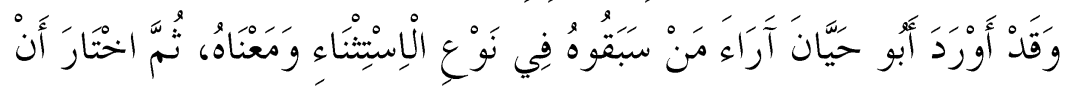

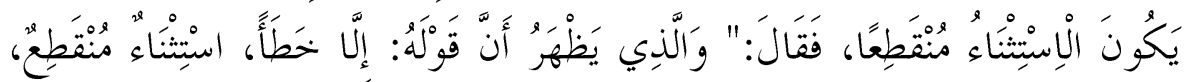

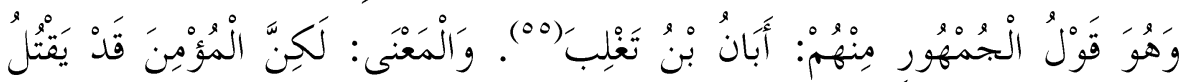

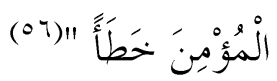
rY

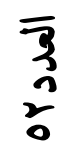

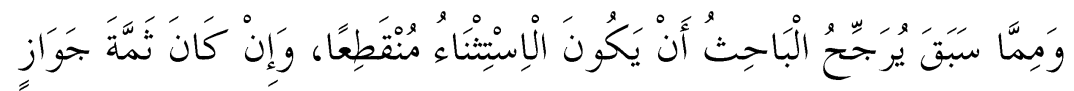

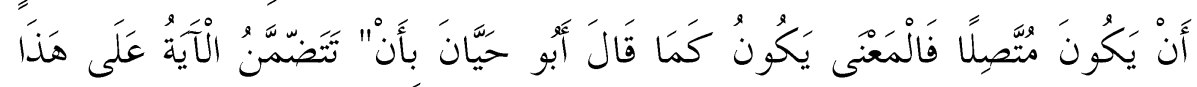

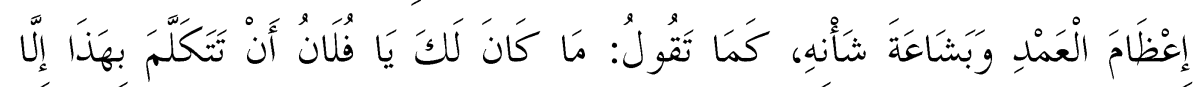

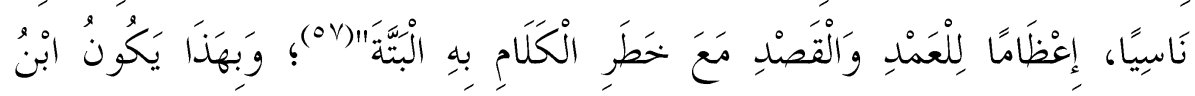

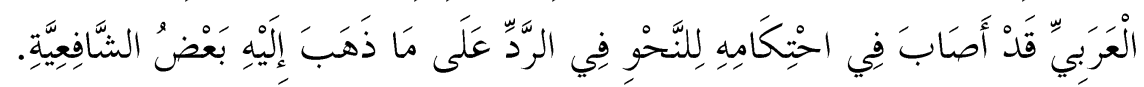

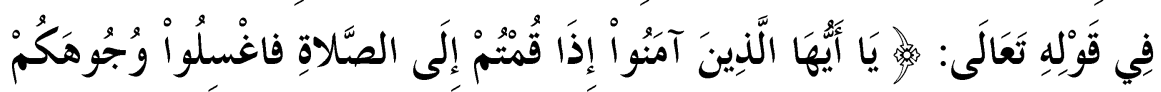

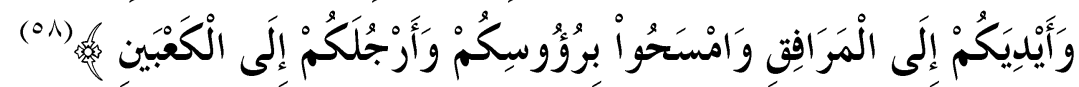

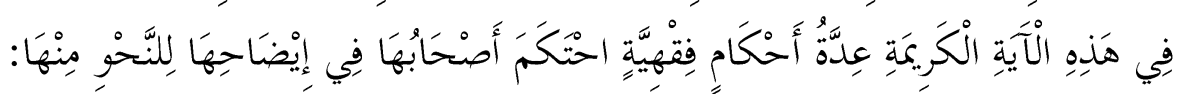




\section{الْمَسْنَأَلَة الرَّابعَةُ:

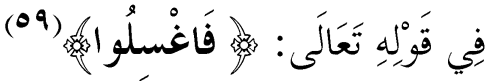

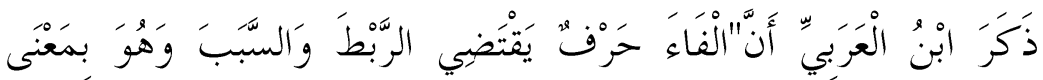

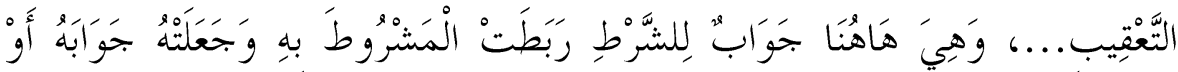

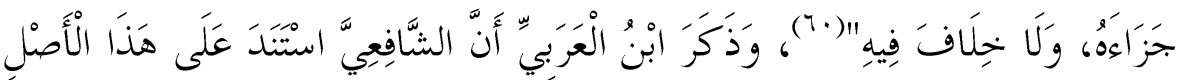

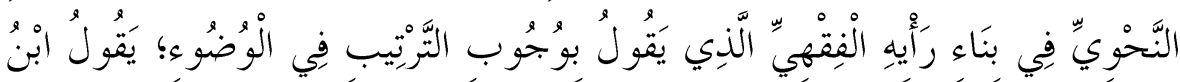

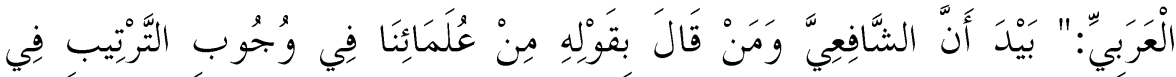

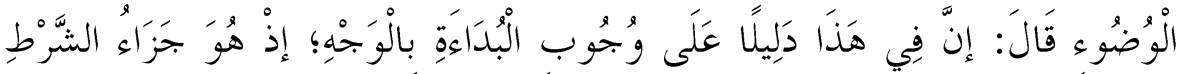

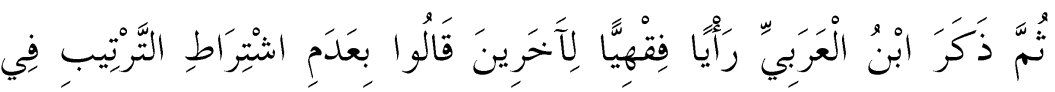

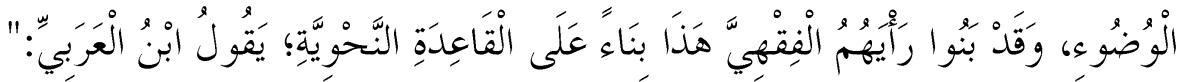

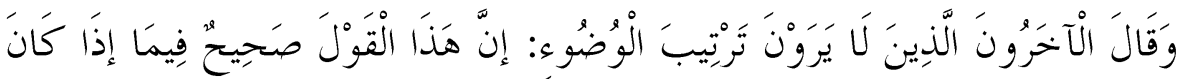

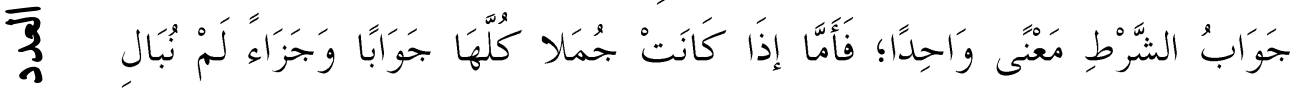

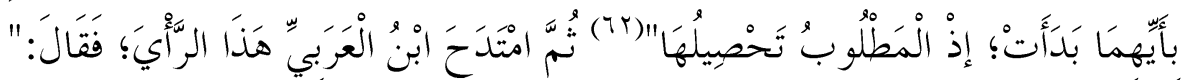

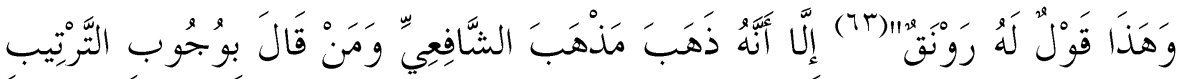

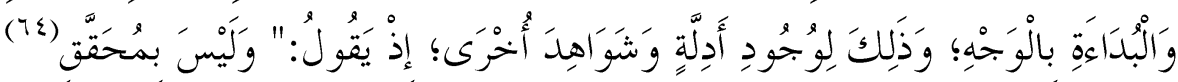

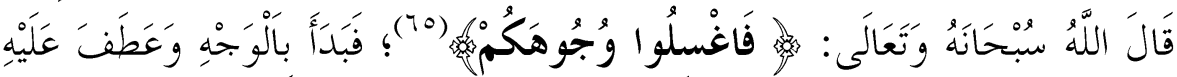

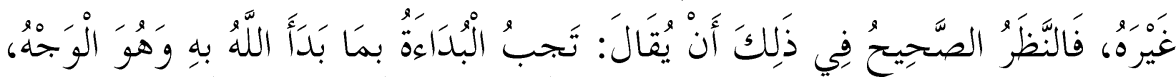

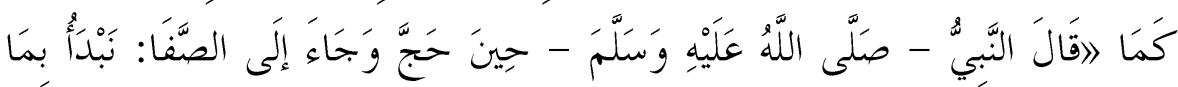

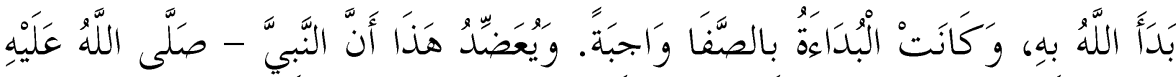

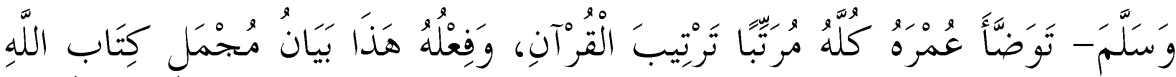

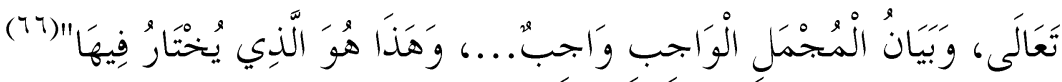




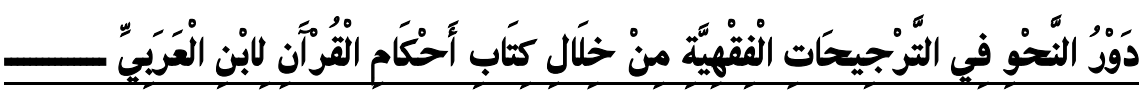

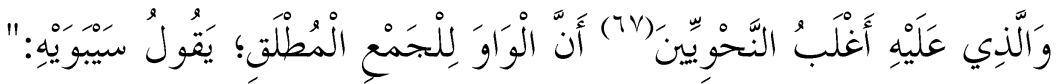

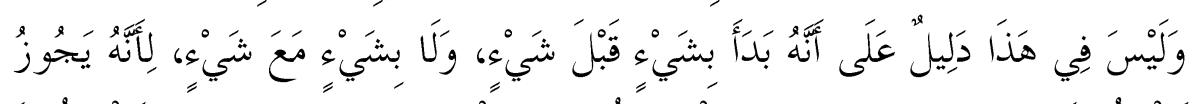

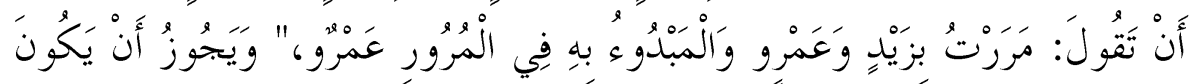

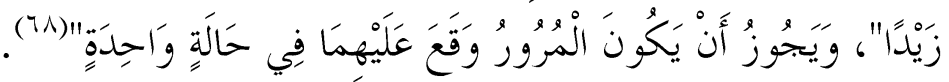

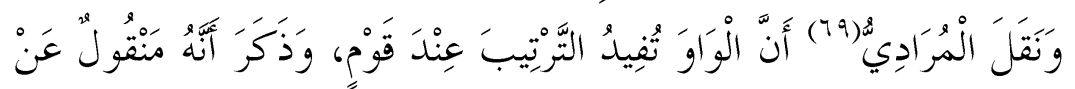

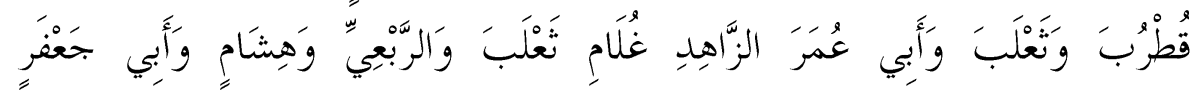
الدَينوريِّ.

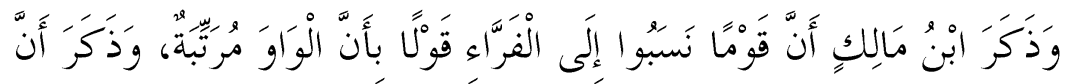

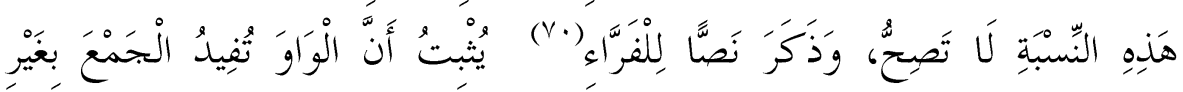

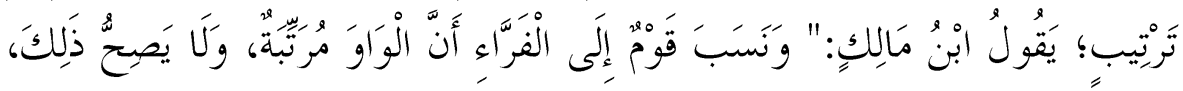

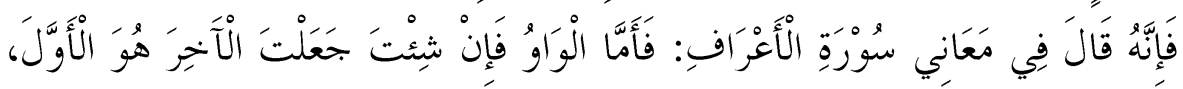

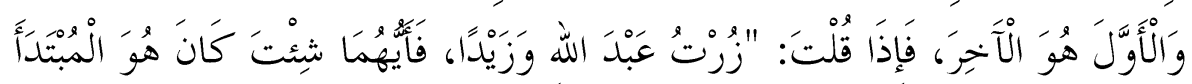

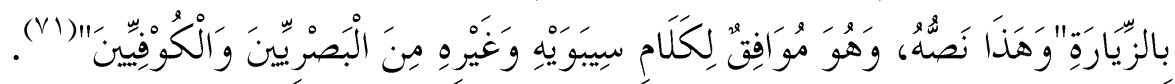

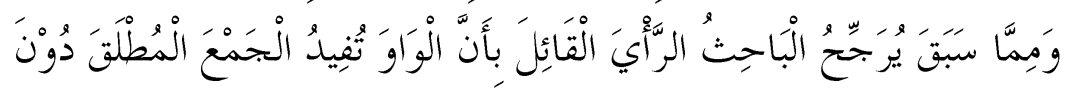

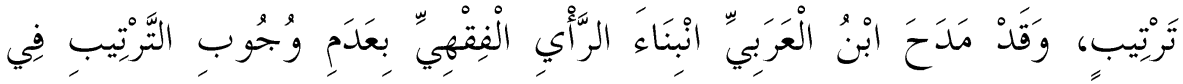
势

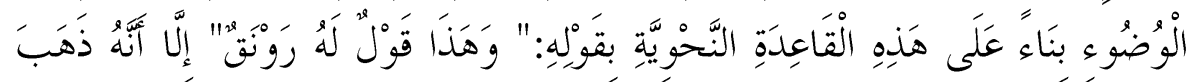

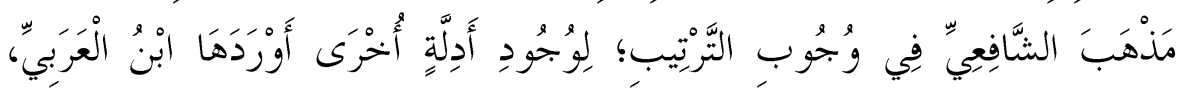

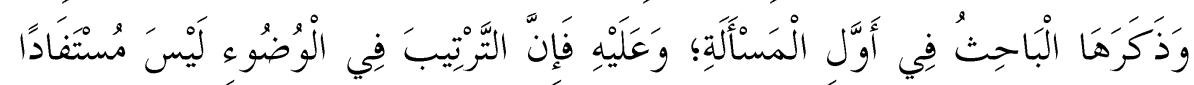

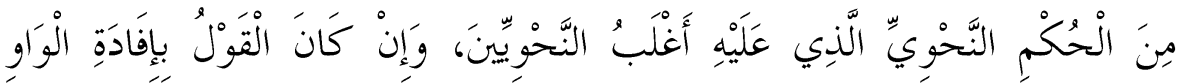

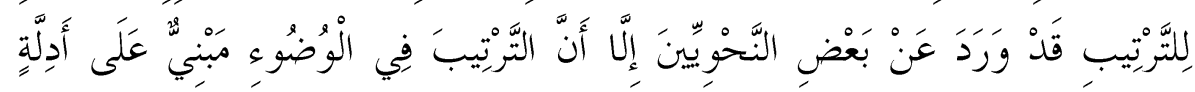

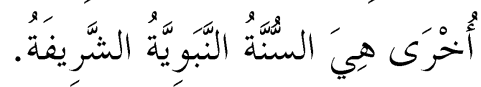




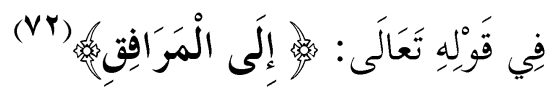

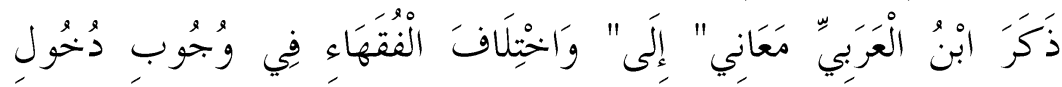

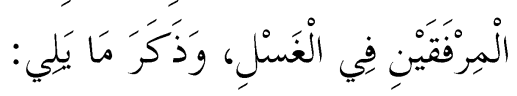

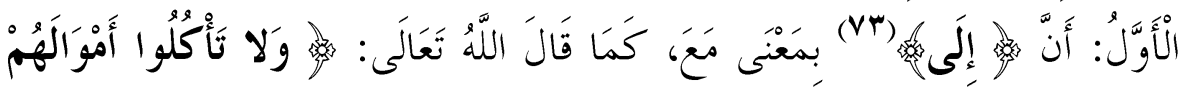

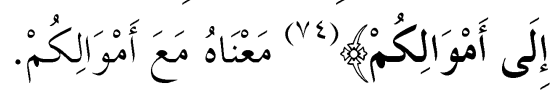

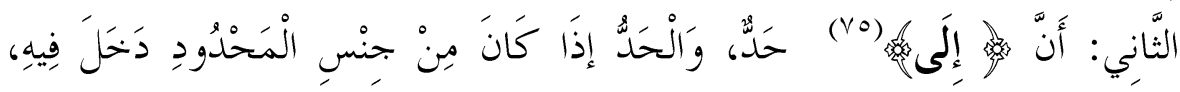
تَقْول:

势

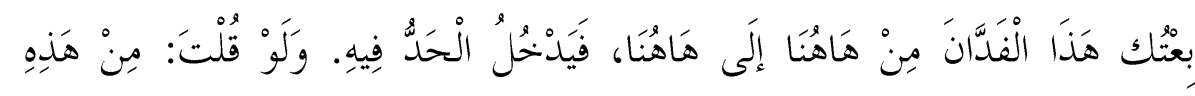

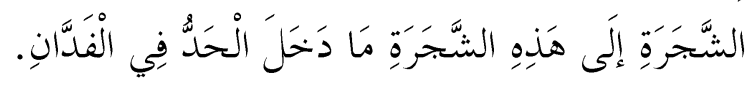

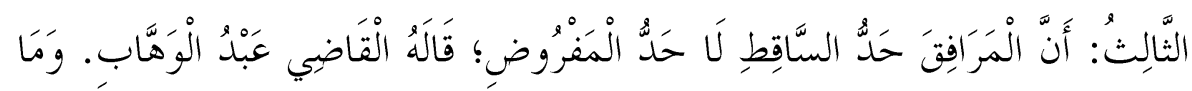

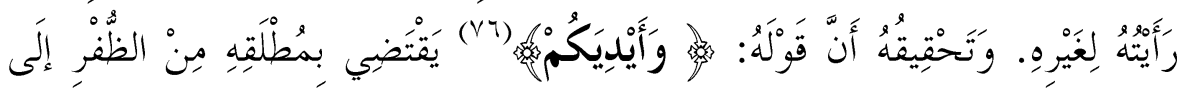

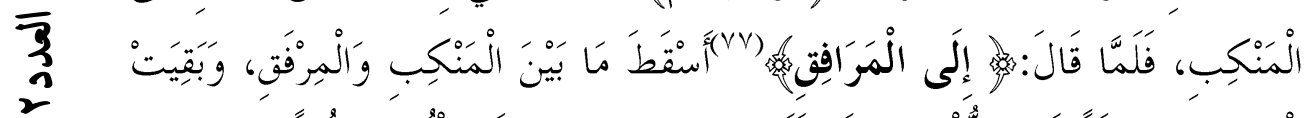

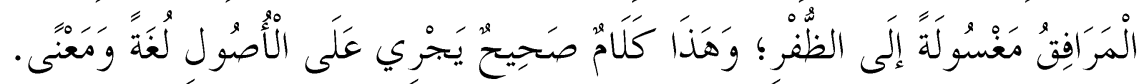

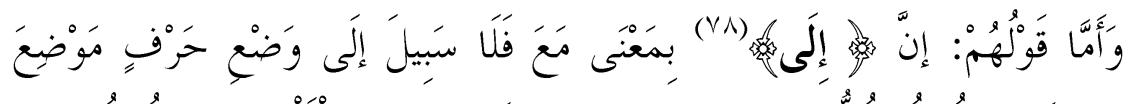

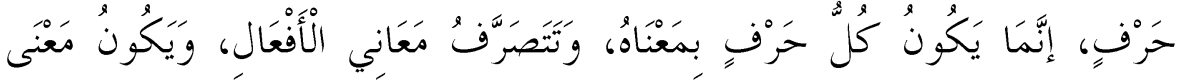

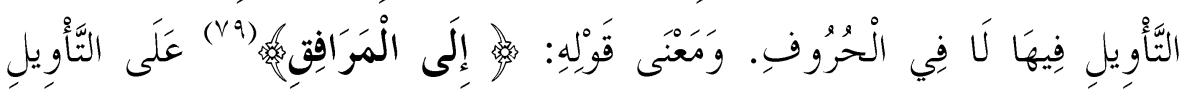

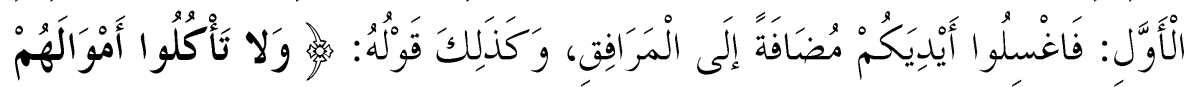

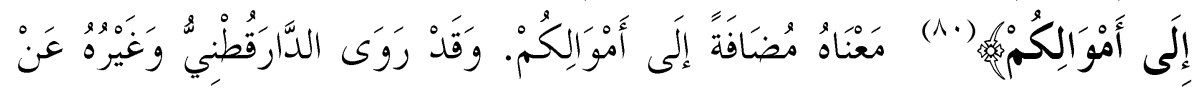

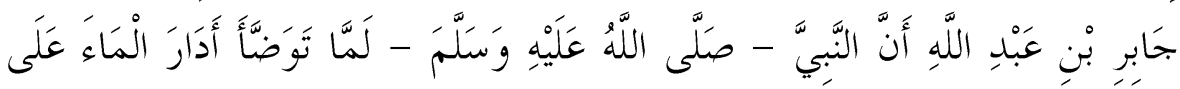

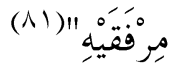




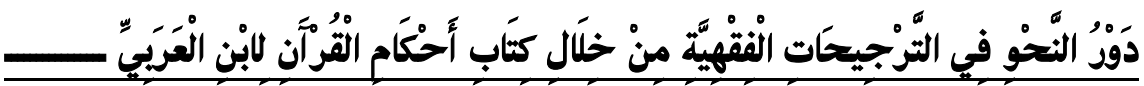

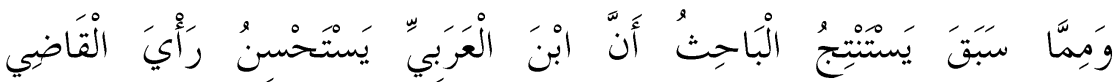

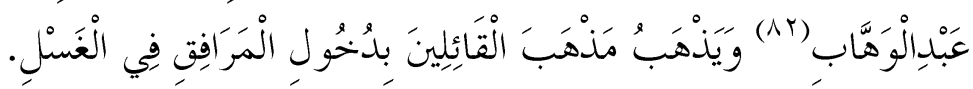

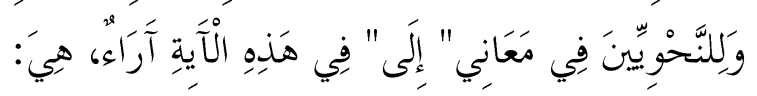

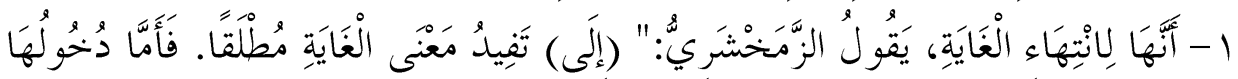

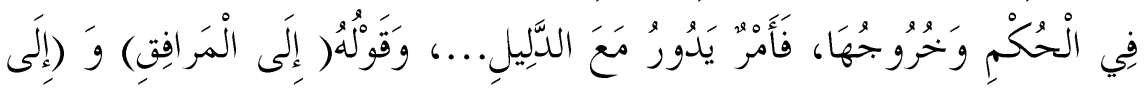

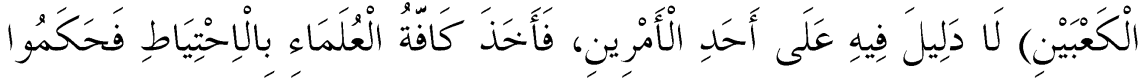

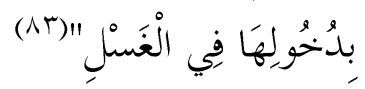

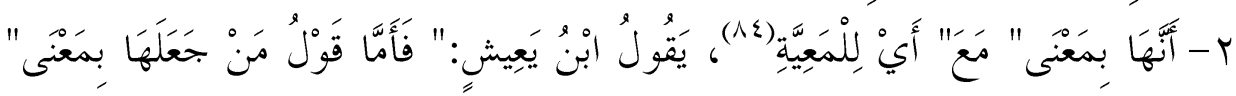

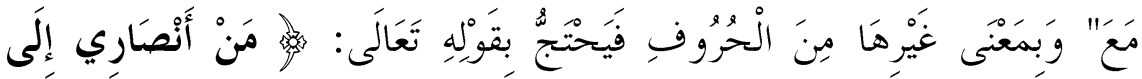

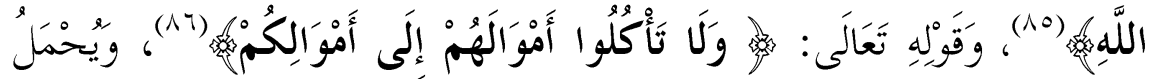

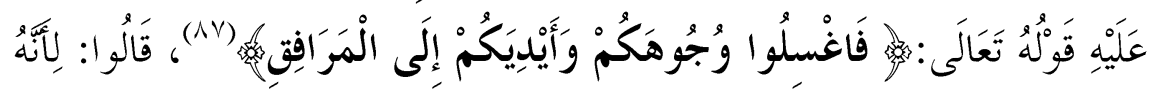

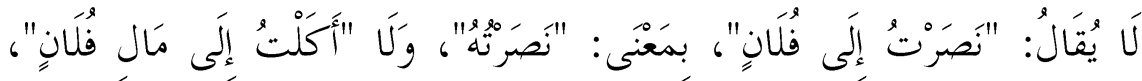

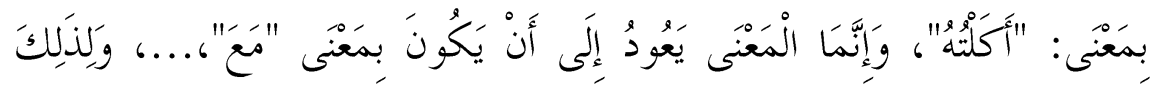

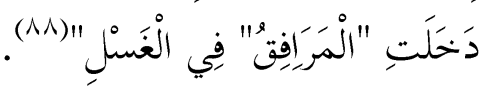

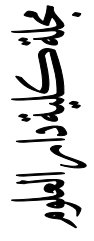

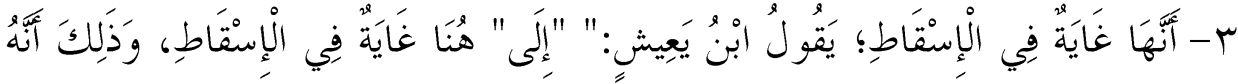

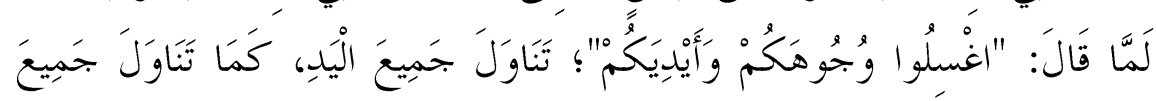

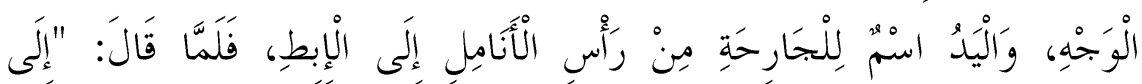

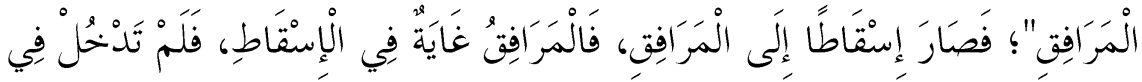

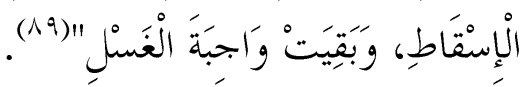

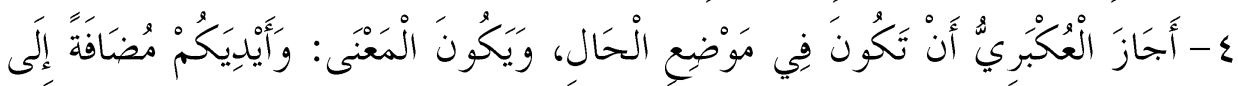

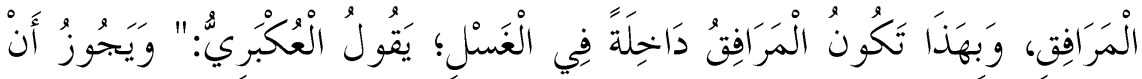

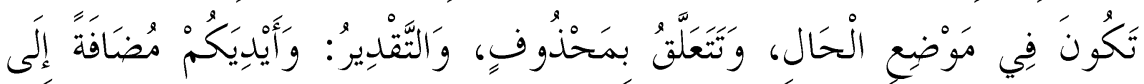

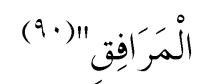




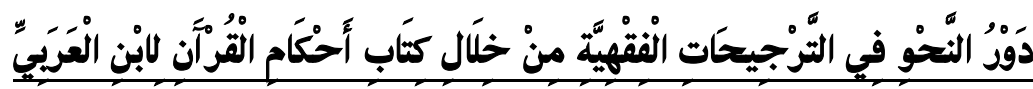

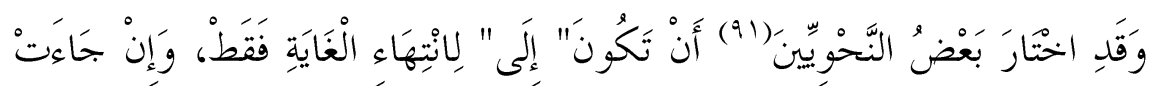

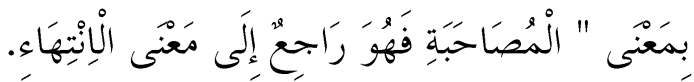

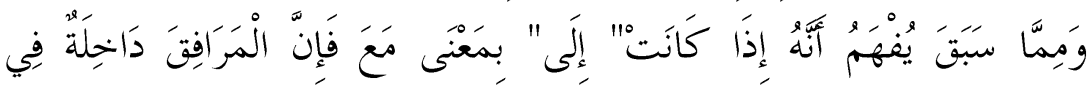

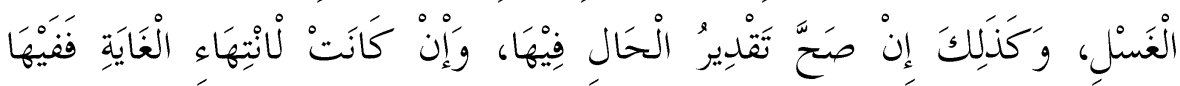
وَجَجَْانِ:

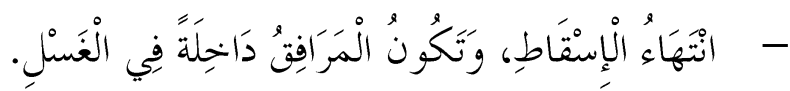

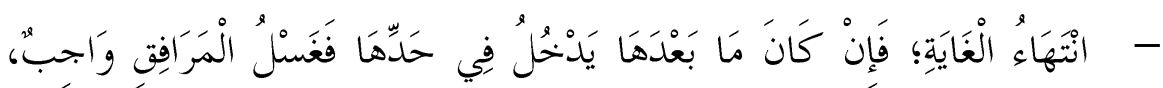

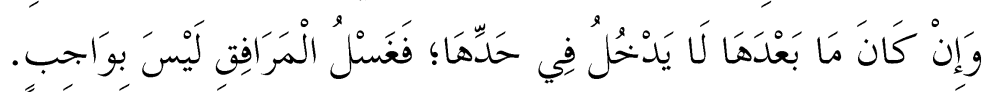

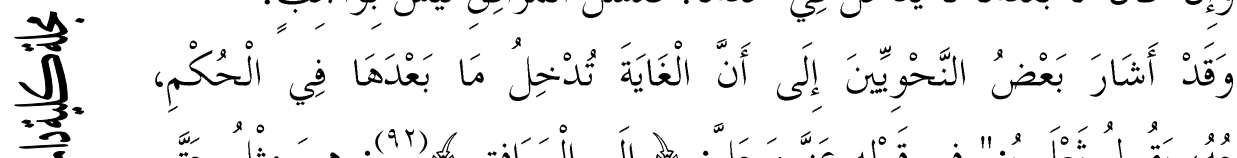

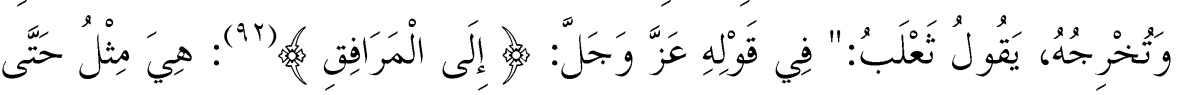

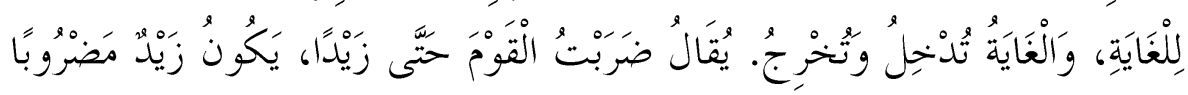

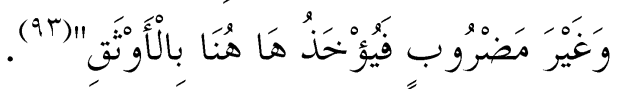

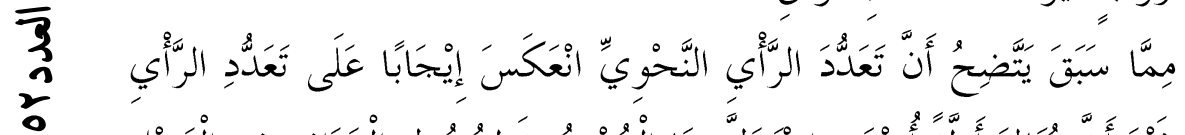

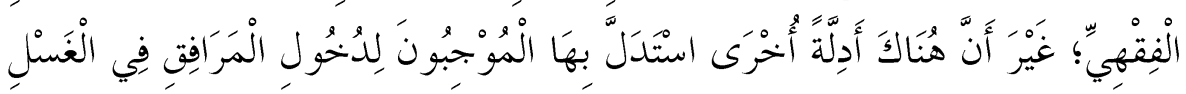

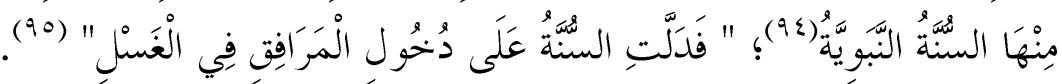

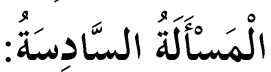

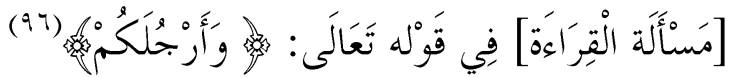

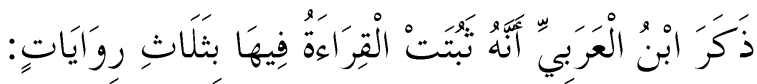

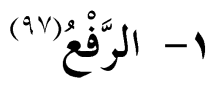

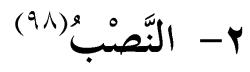

$$
\begin{aligned}
& \text { ب- الْجرَّ(99). }
\end{aligned}
$$




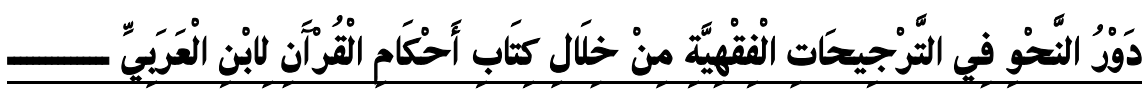

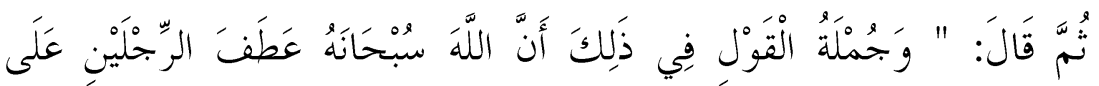

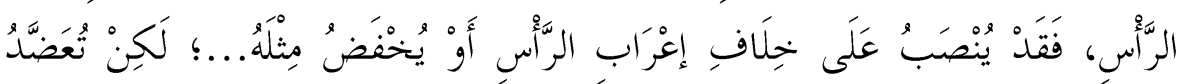

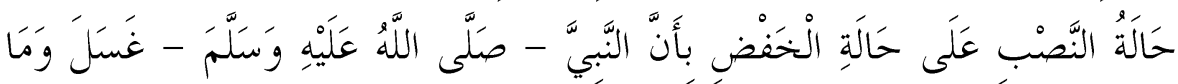

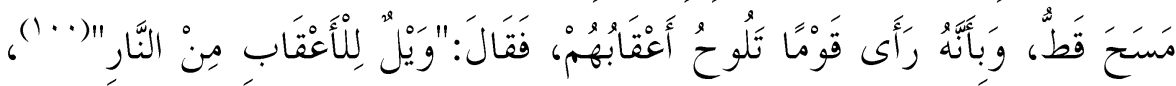

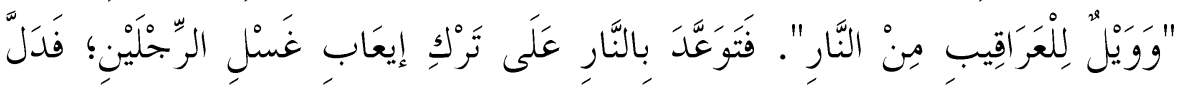

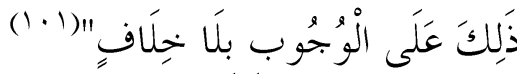

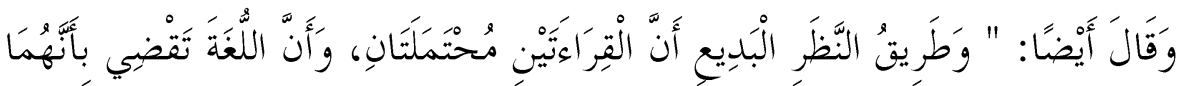

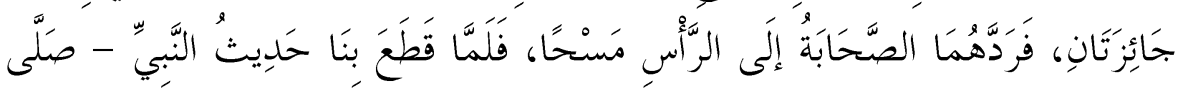

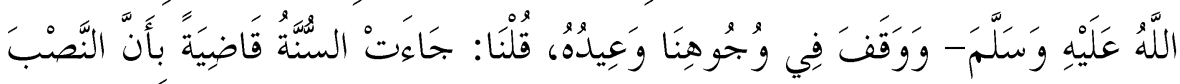

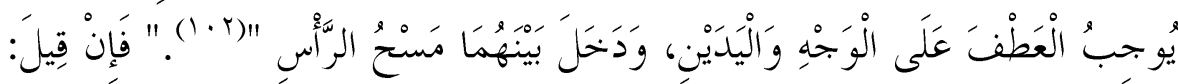

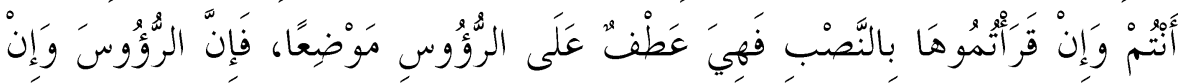

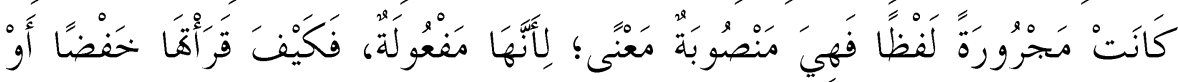

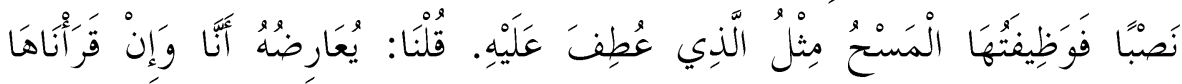

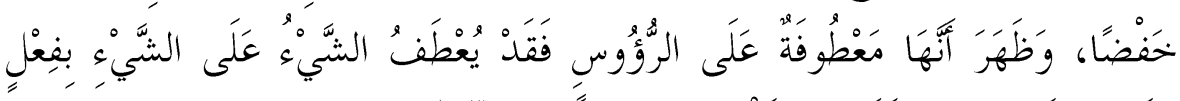

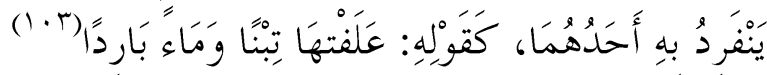

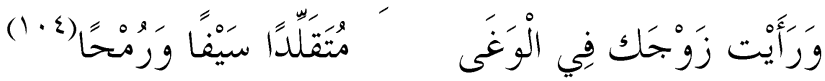

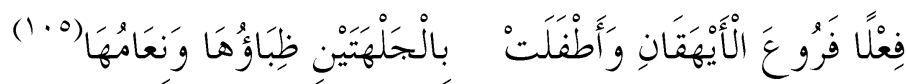

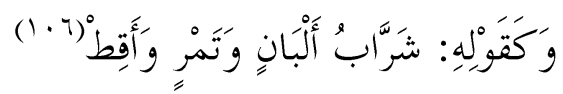
Y

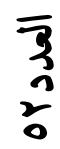

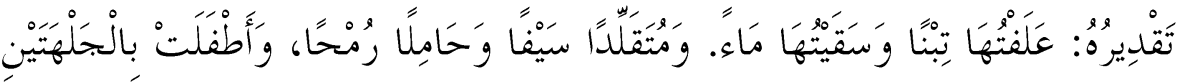

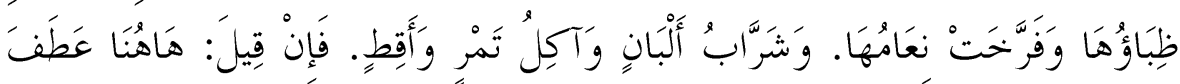

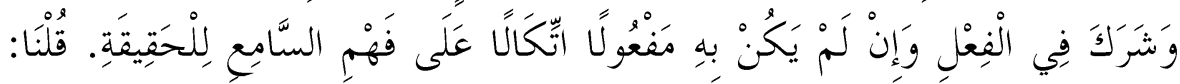

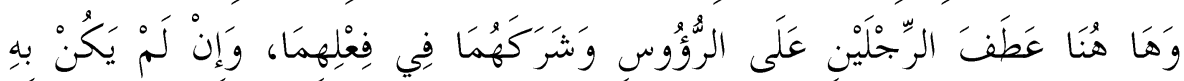

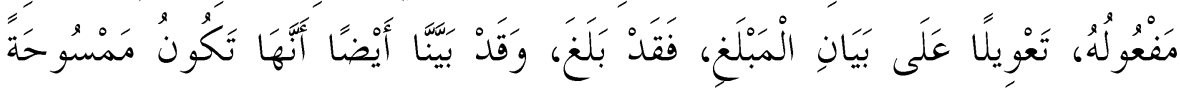

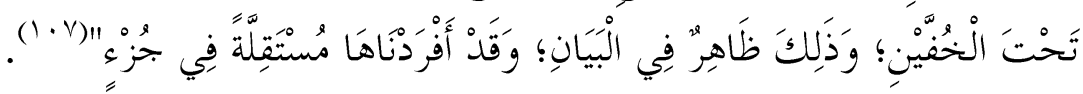




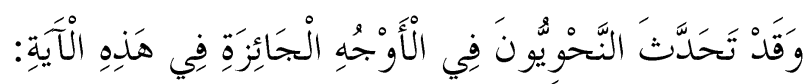

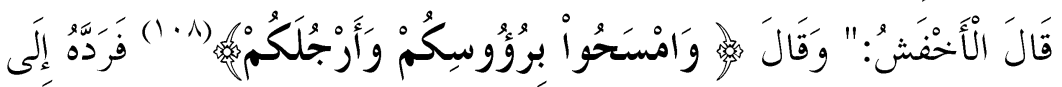

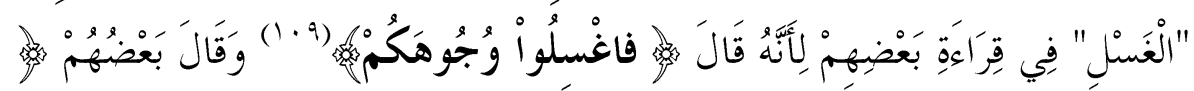

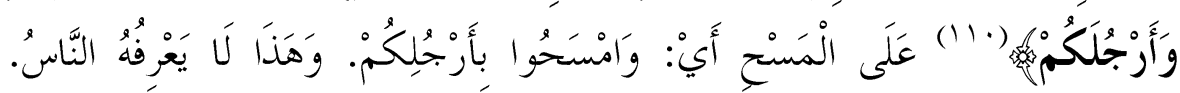

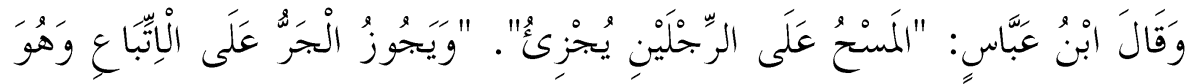

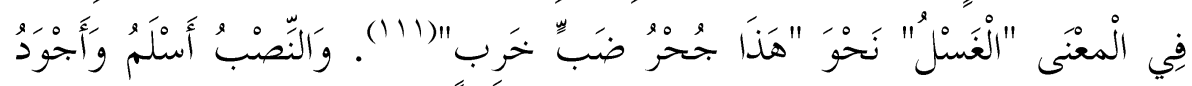

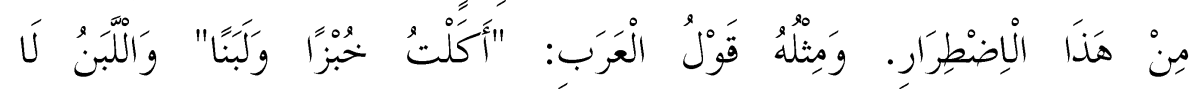

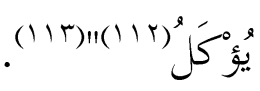

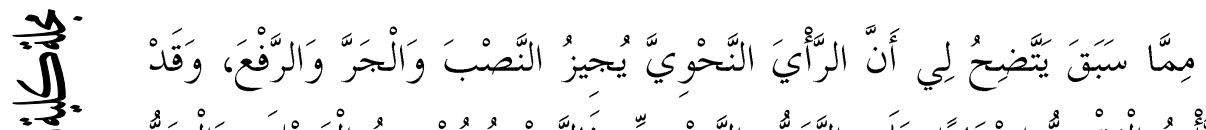

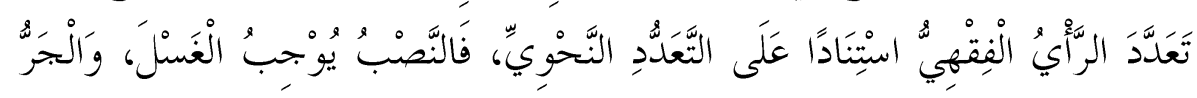

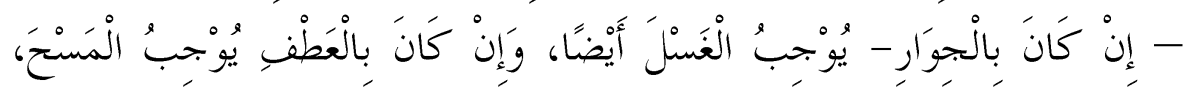

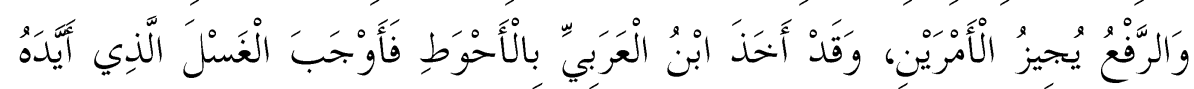

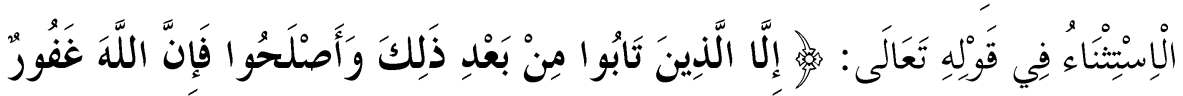
) رحيم" (1) (1)

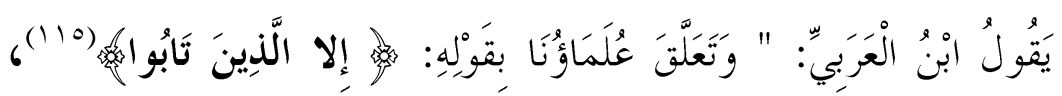

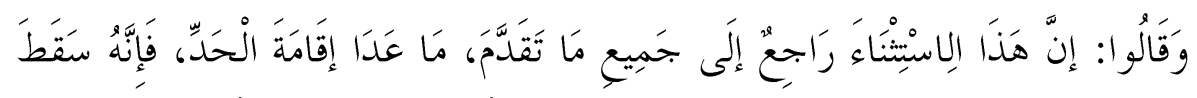

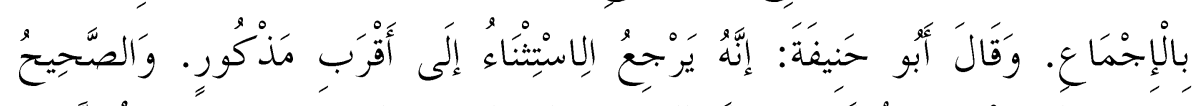

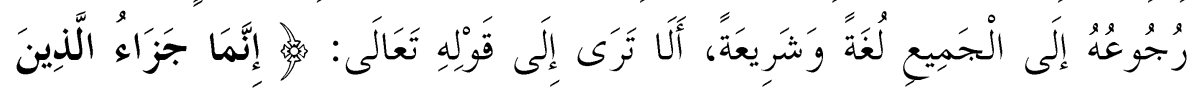

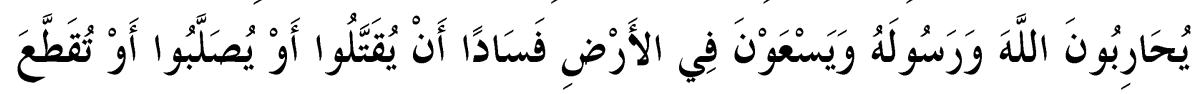

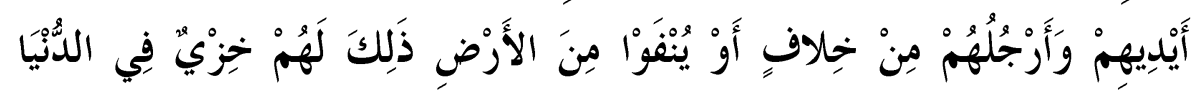




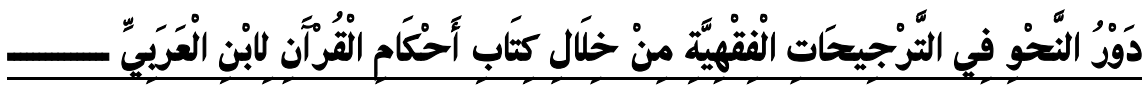

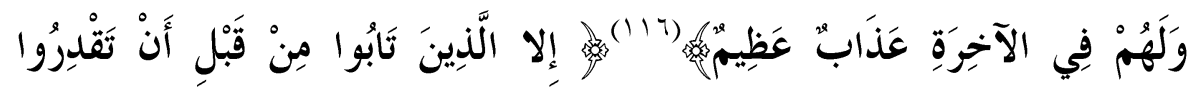

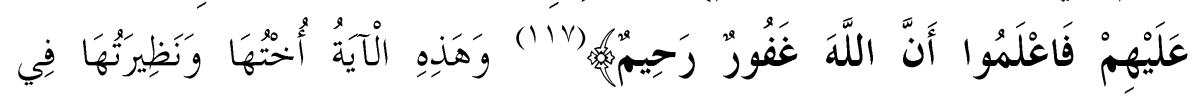

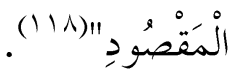

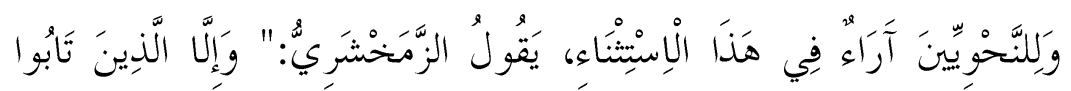

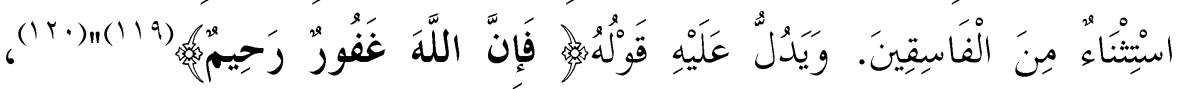

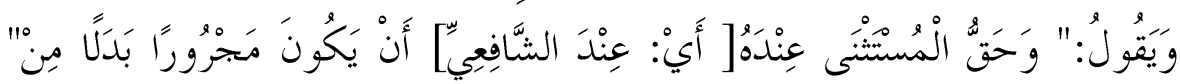

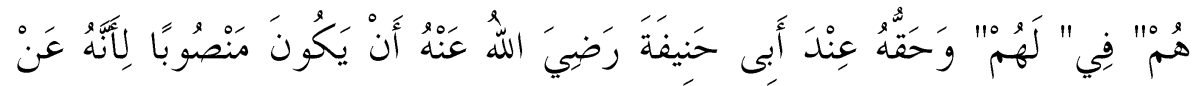

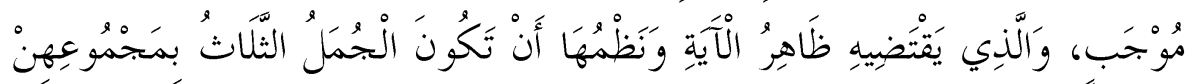

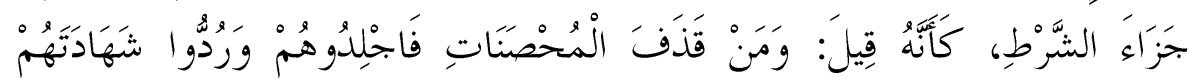

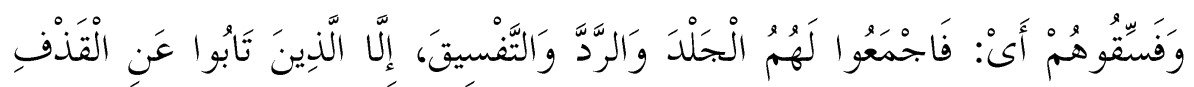

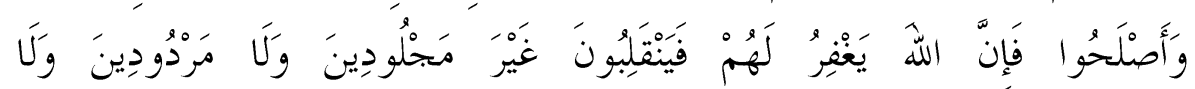

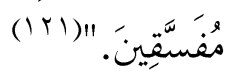

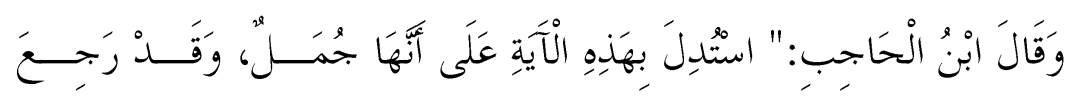

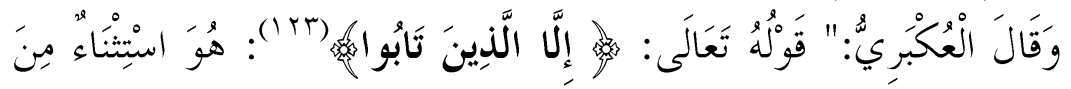

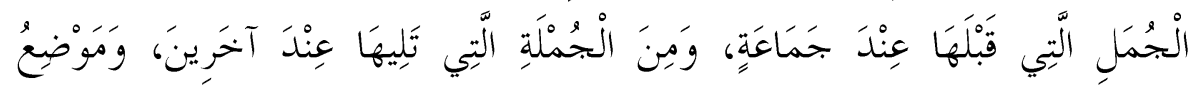

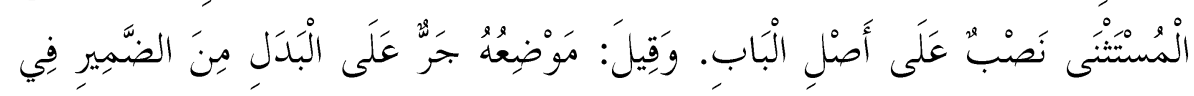

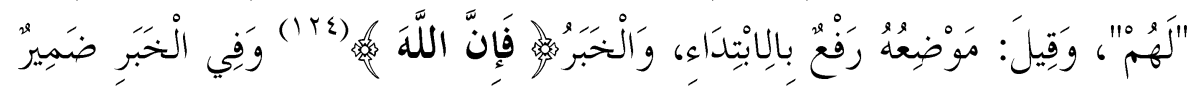

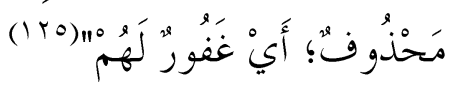

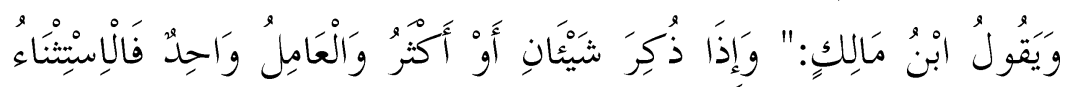

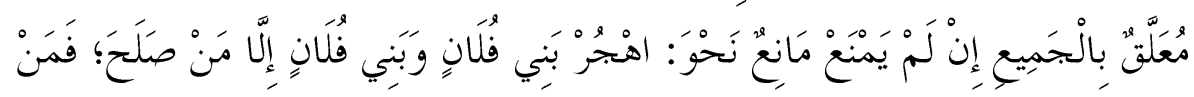

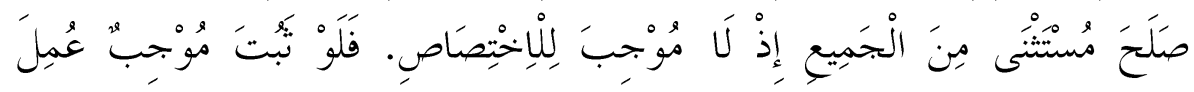

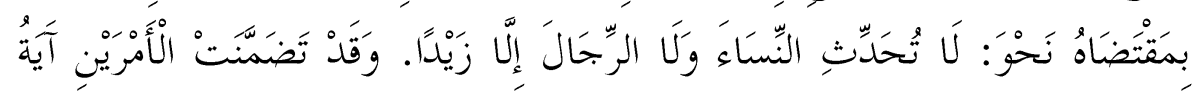




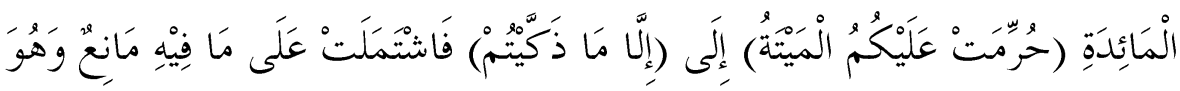

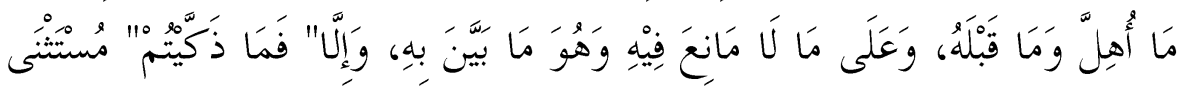

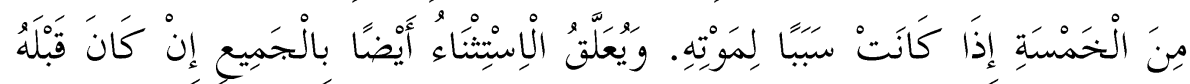

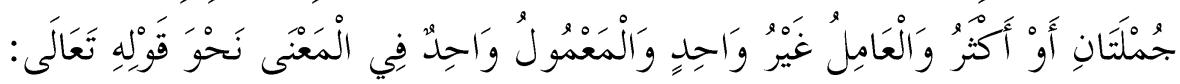

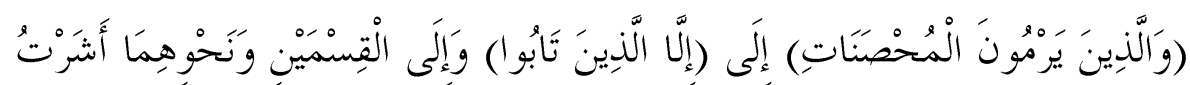

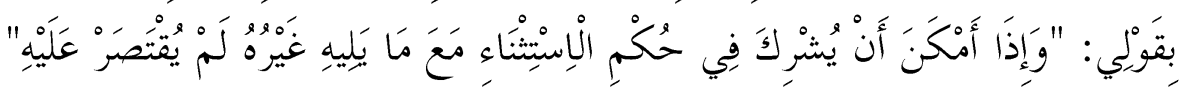

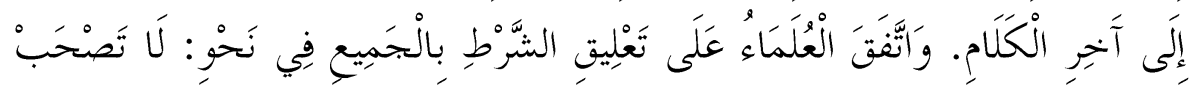

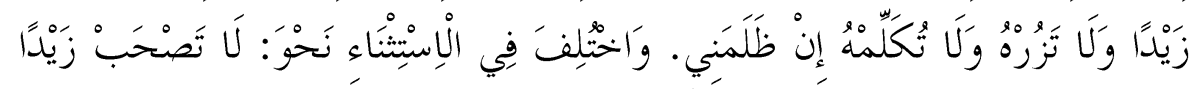

势

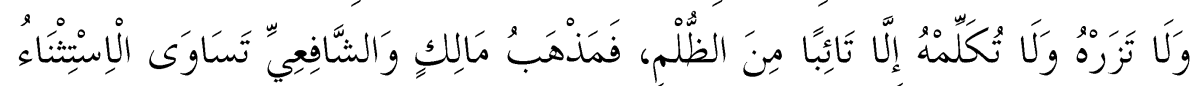

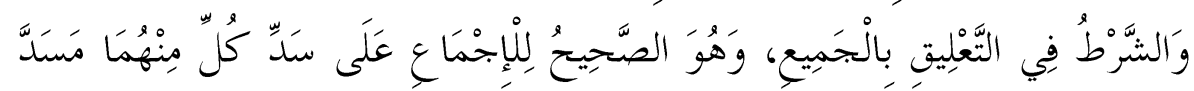

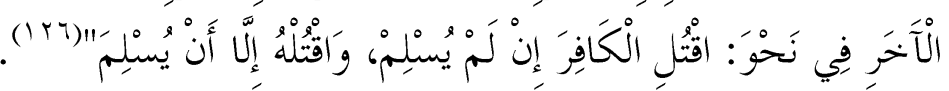

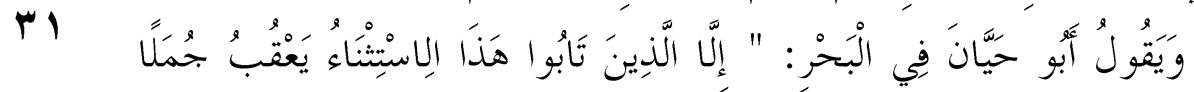

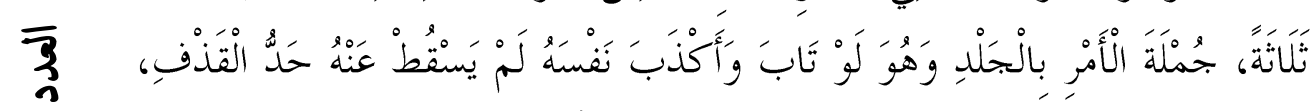

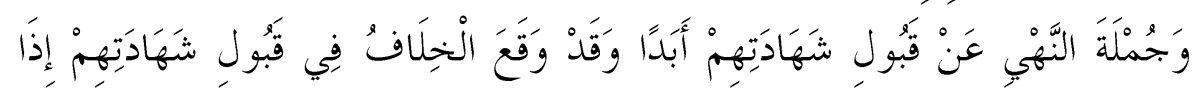

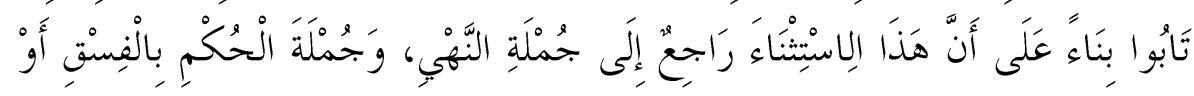

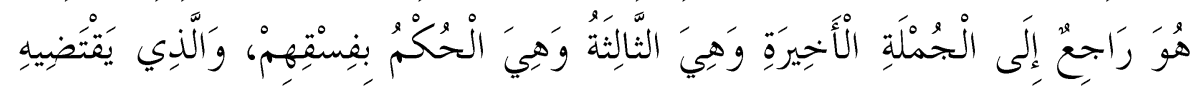

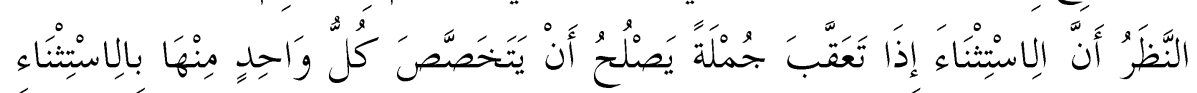

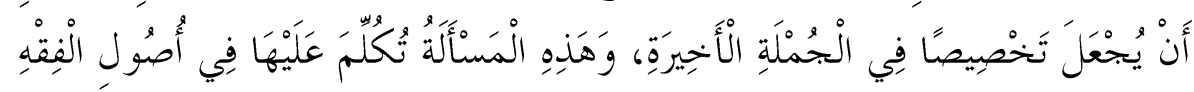

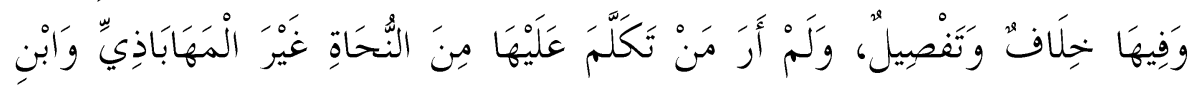

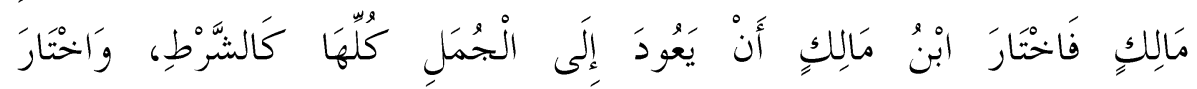

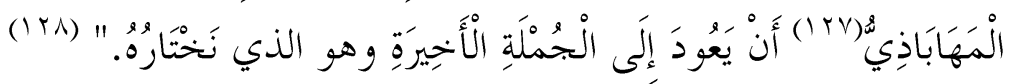

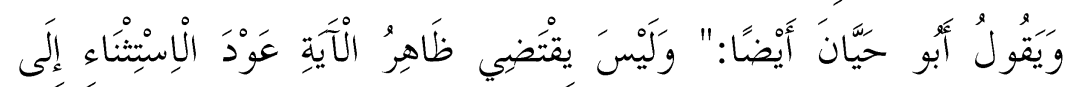

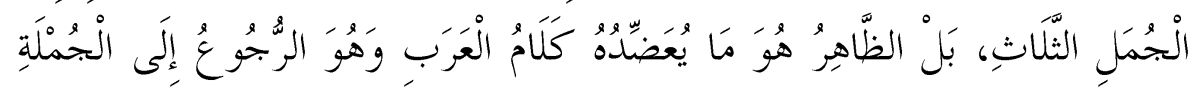




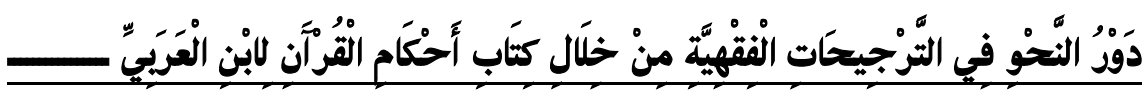

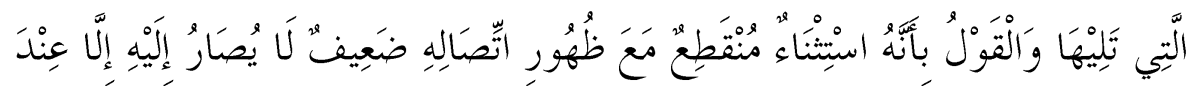

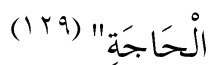

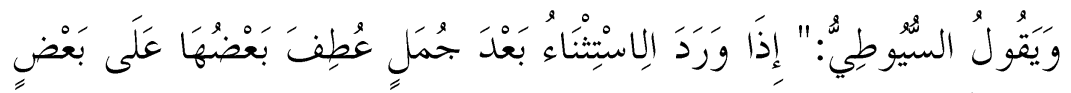

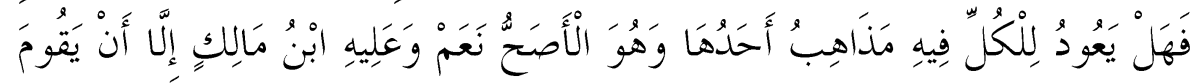

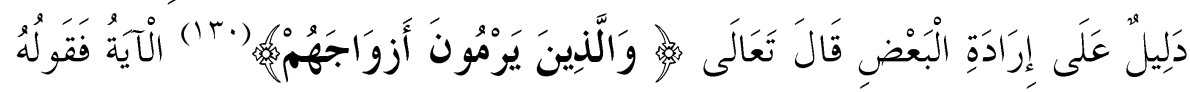

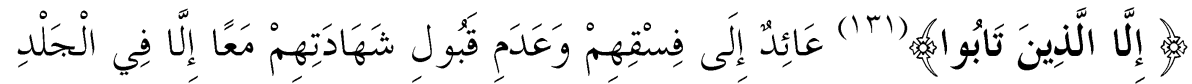

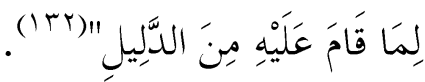

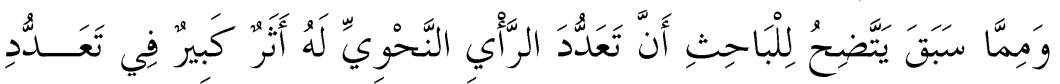

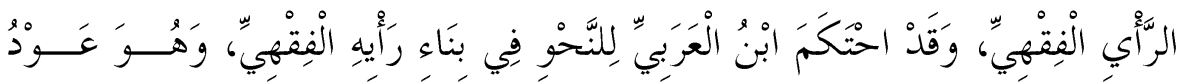

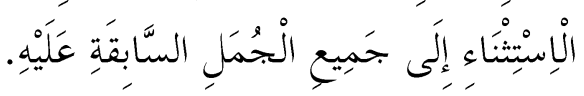

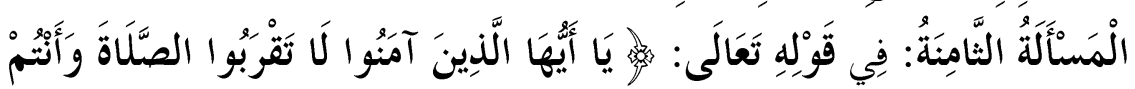

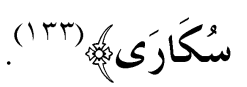

告

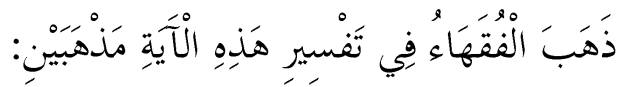

rY

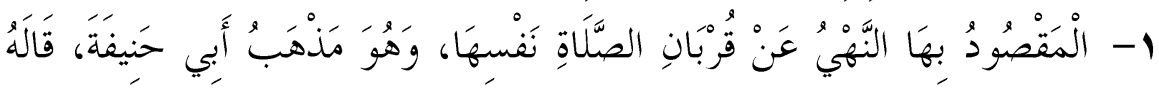

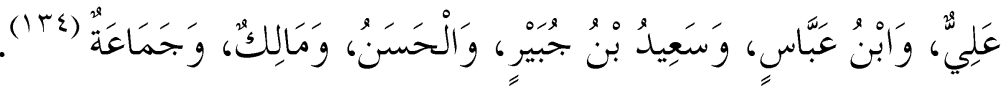

$\overline{3}$
3
2
0

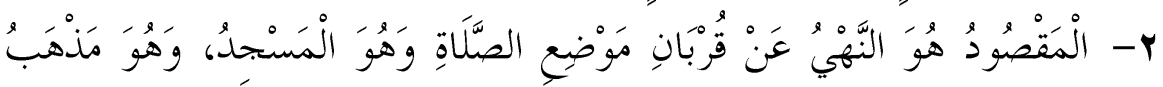

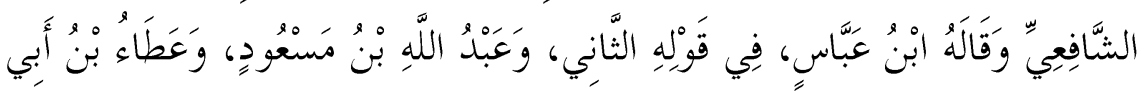

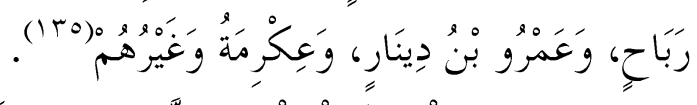

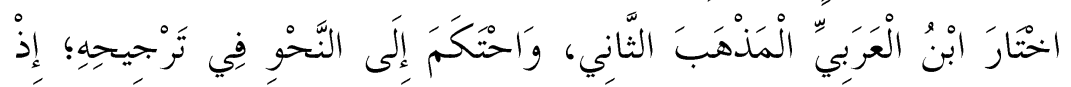

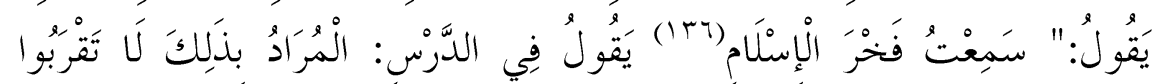

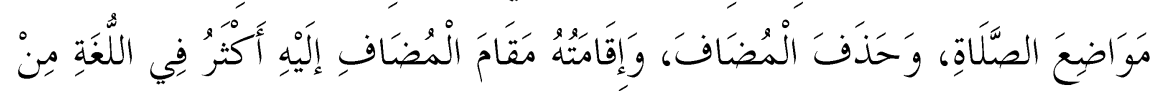

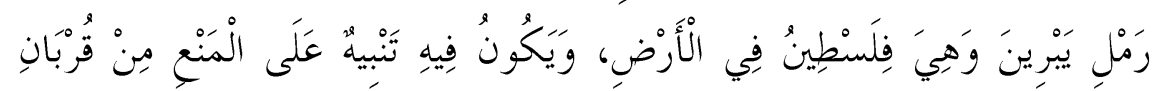

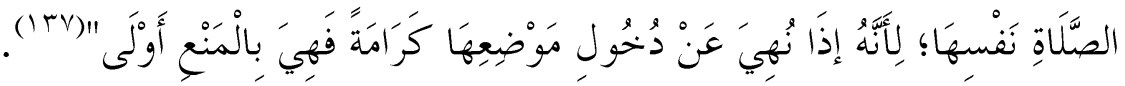




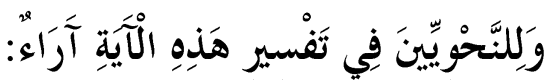

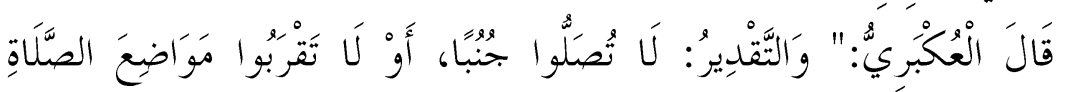

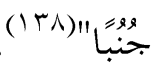

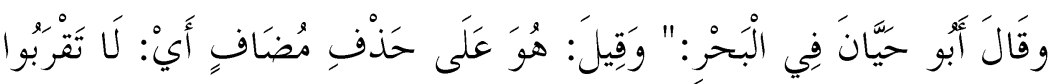

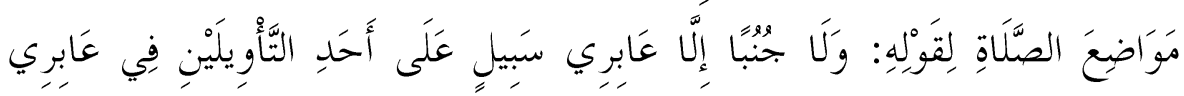

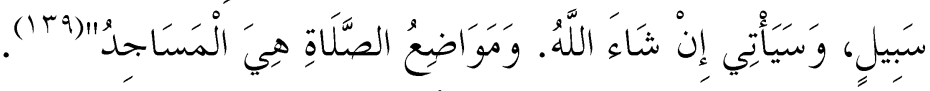

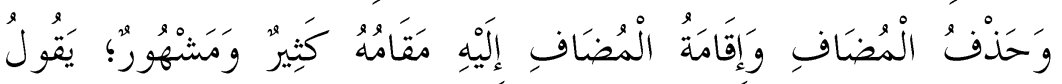

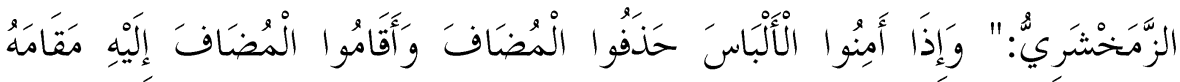

势

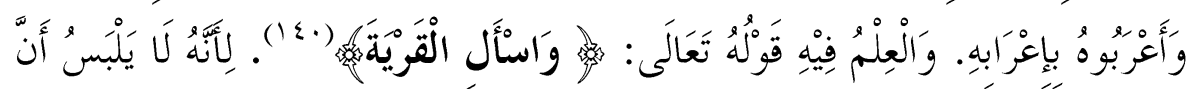

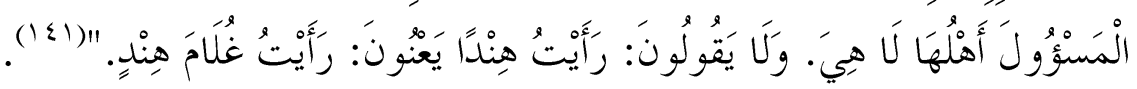

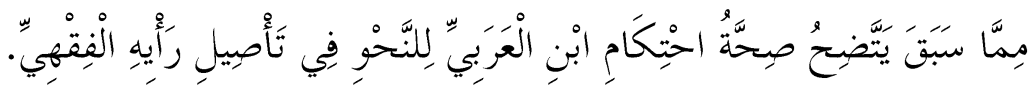

rr

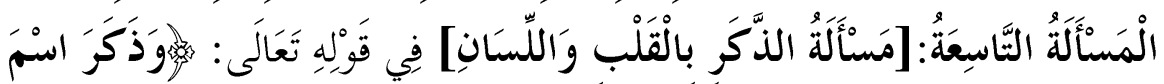

高

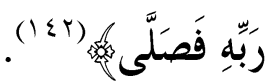

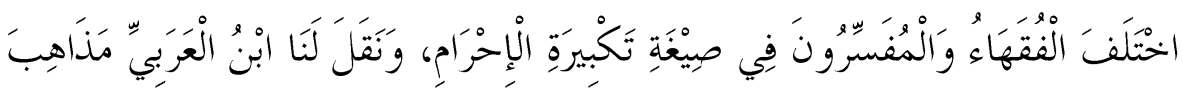

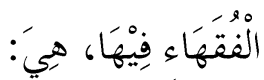

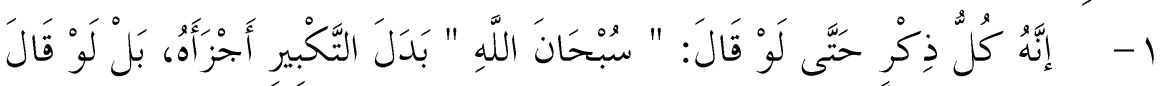

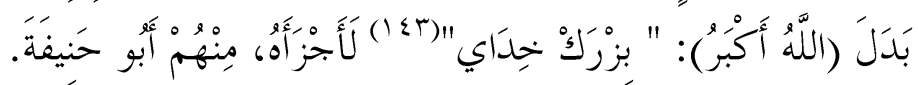

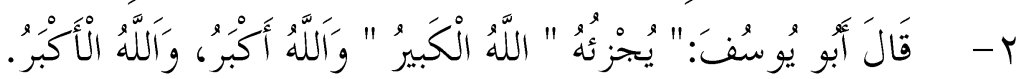

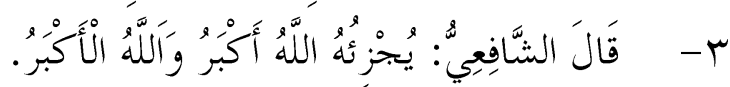

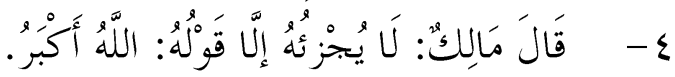

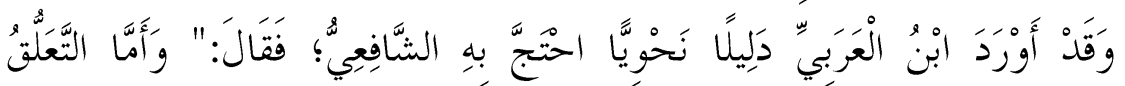

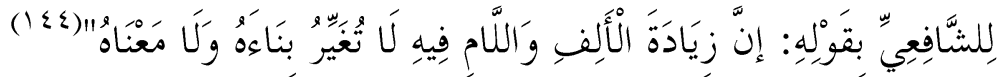




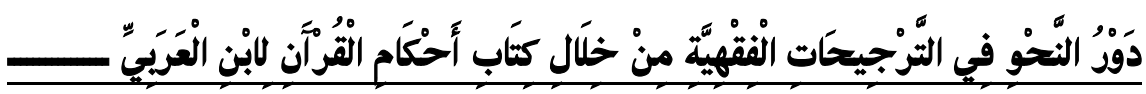

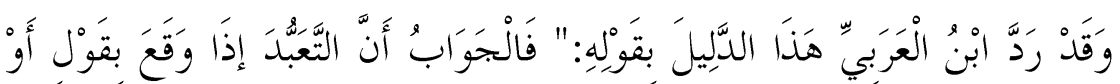

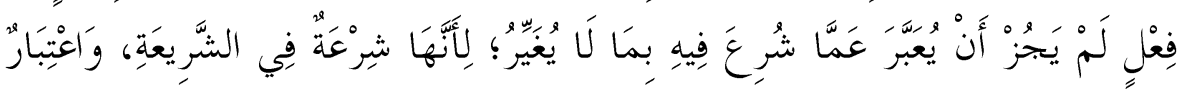

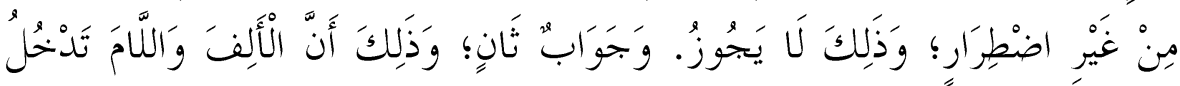

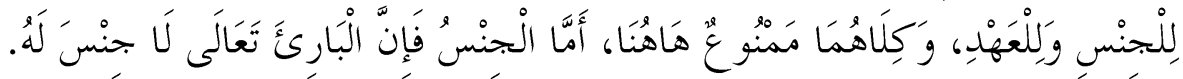

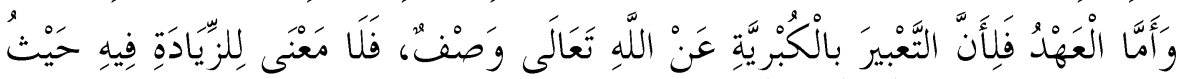

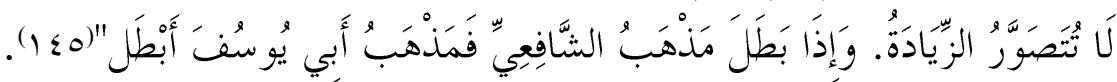

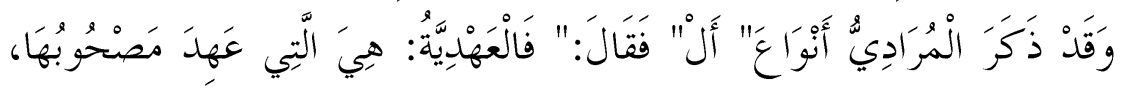

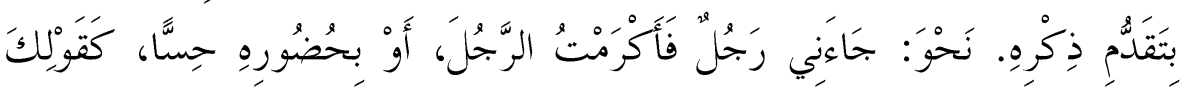

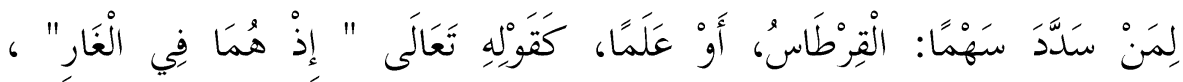

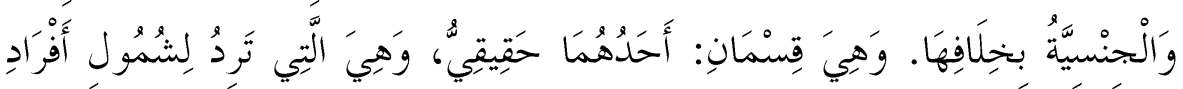

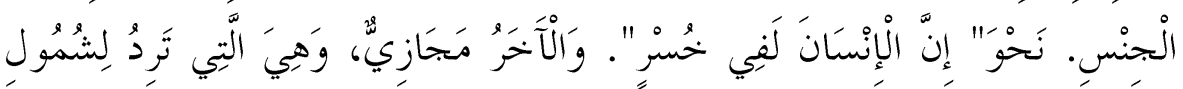

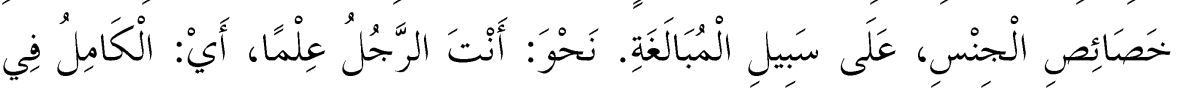

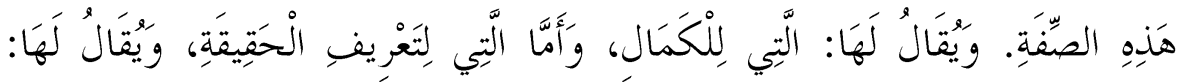

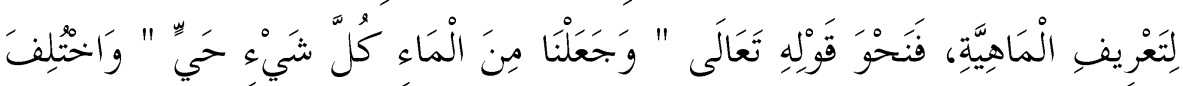

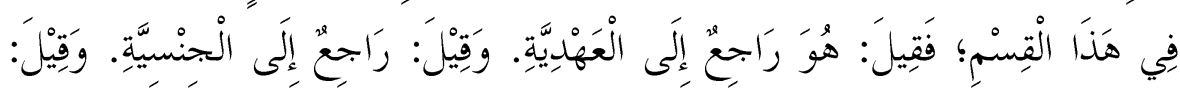

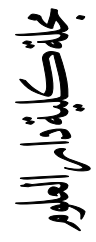
rร

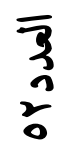

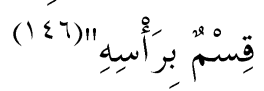

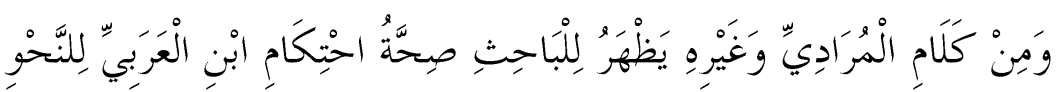

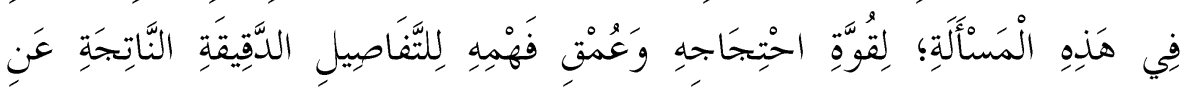

\section{الأخغاتمناُ}

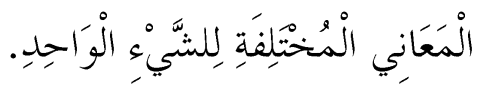

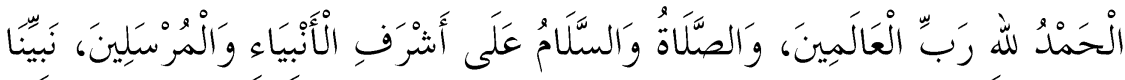

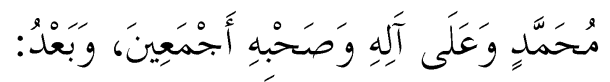

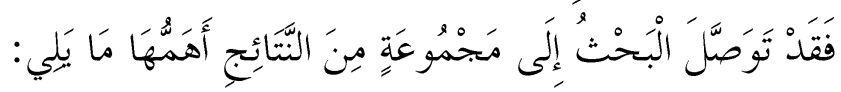




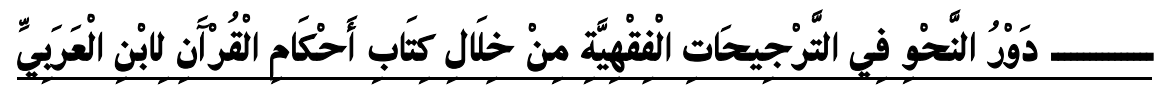

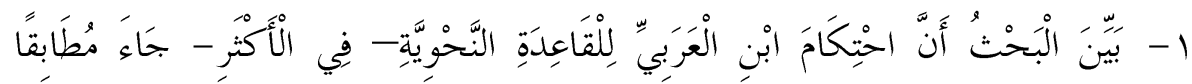

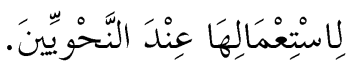

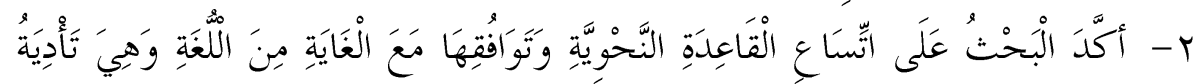

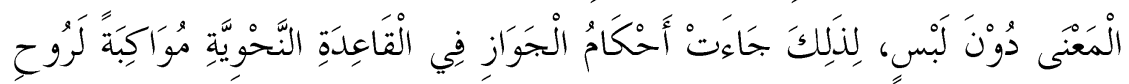

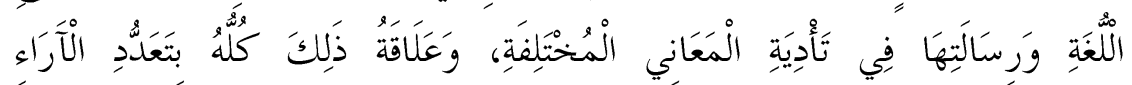
وَالْمَذَاهِبَ الْفِقْهِيَّة.

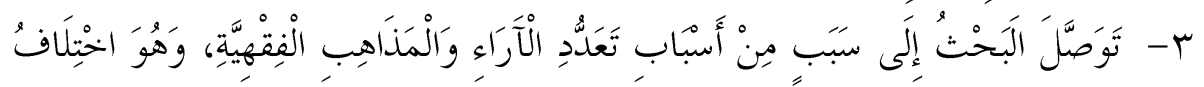

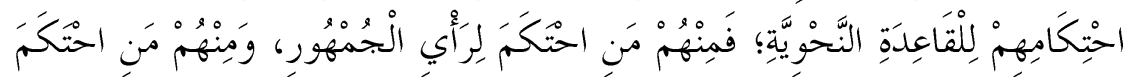

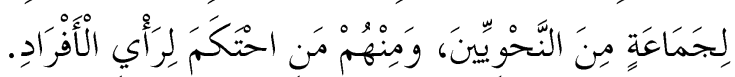

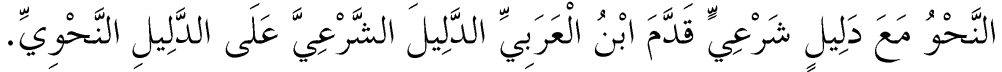

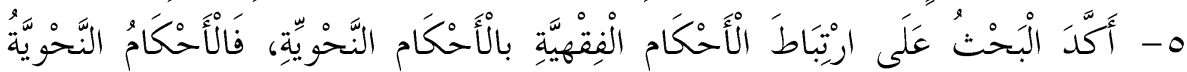

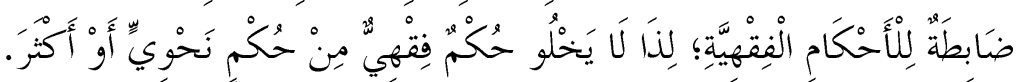

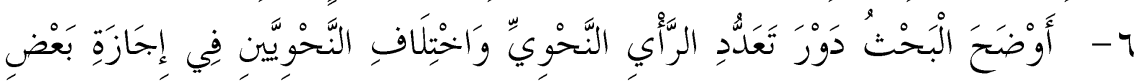

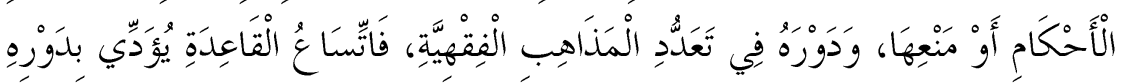

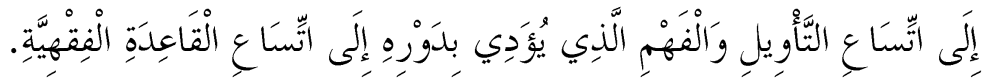

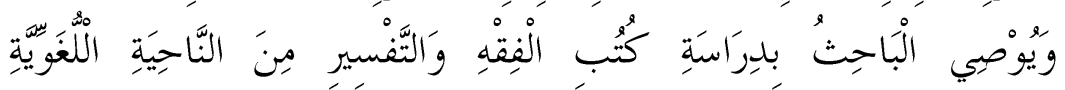

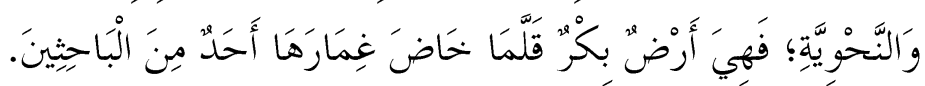

\section{الإمسادووالئراجع}

1- الأخفش: معاني القرآن، تحقيق: د/ هدى محمود قراعة، مكتبــة الخـــانجي، القـــاهرة،

$$
. \text {. } 199 \cdot=\longrightarrow 1 \leqslant 11
$$

ץ- الأشمون: شرح الأشموني على ألفية ابن مالك، تحقيق: محمد محيي الدين عبدالحميد، دار

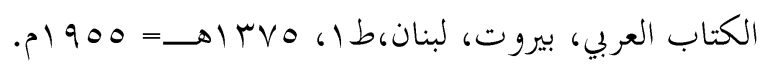




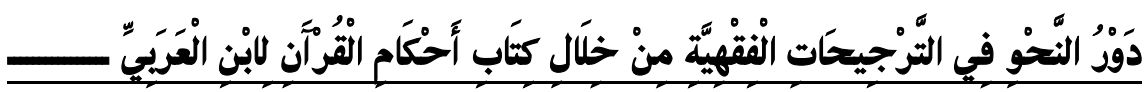

r- الأنباري(أبو البركات): الإنصاف في مسائل الخلاف بين النحويين البصريين والكوفيين،

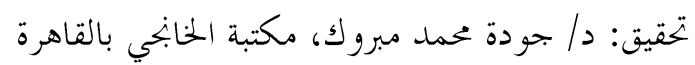

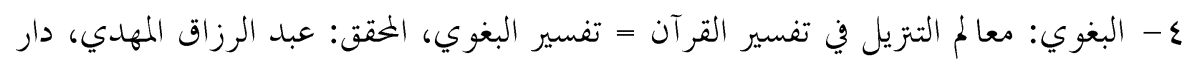

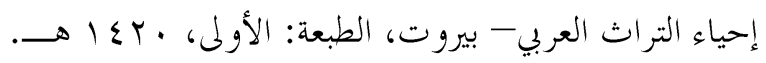

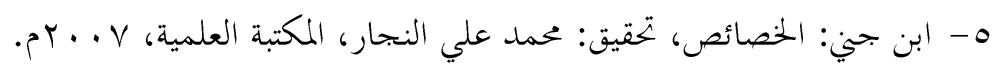

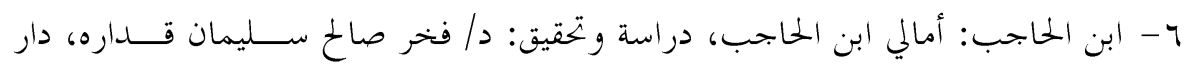

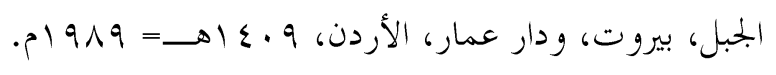

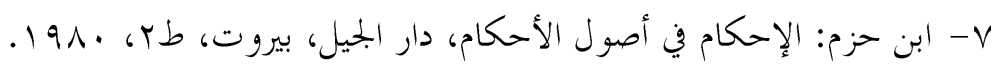

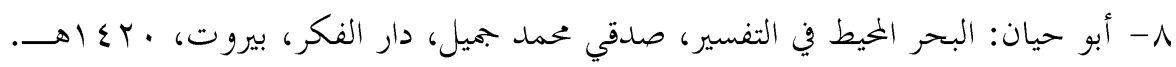

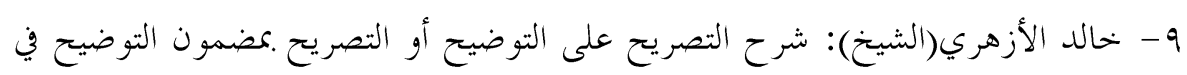

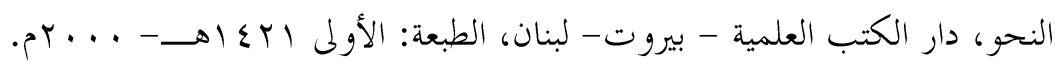

$$
\text { • إبن خحلدون: المقدمة، دار القلم، بيروت. }
$$

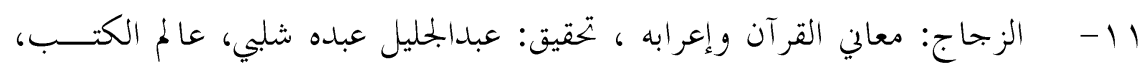

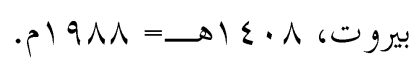

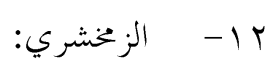

- الكشاف عن حقائق غو امض التزيل، دار الكتاب العربي - بيروت، الطبعة: الثالثة

$$
\rightarrow 1 \varepsilon \cdot V-
$$

- المفصل في صناعة الإعراب، د. علي بو ملحم، مكتبة الهلال - بيروت، الطبعـة:

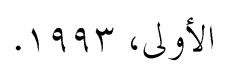

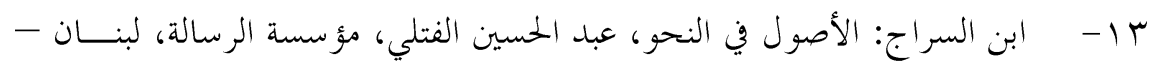

$$
\text { بيروت. }
$$

ع ا- - السمين الحلبي: الدر المصون في علوم الكتاب المكنون، د/ أحمد محمد الخراط، دار

$$
\text { القلم، دمشق. }
$$

ه- - إيبويه: الكتاب، عبد السلام محمد هارون، مكتبة الخانجي، القاهرة، الطبعسة:

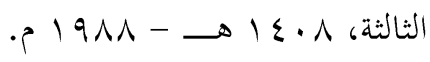




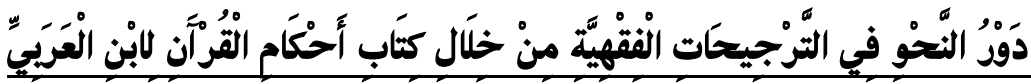

17 - السيرافي: شرح أبيات سيبويه، الدكتور محمد علي الريح هاشم، راجعه: طه عبد الرؤوف سعد، مكتبة الكليات الأزهرية، دار الفكر للطباعة والنشر والتوزيع، القاهرة

$$
\text { . 19V } 198-
$$

V - IV السيوطي: همع الهوامع في شرح جمع الجوامع، عبد الحميد هنــــاوي، المكتبـــة

$$
\text { التوفيقية - مصر. }
$$

11 - ابن الصائغ: اللمحة في شرح الملحة، تحقيق: إبراهيم بن سالم الصاعدي، عمادة

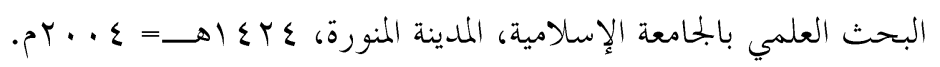

9 - 1 - الصبان: حاشية الصبان على شرح الأشموني لألفية ابن مالك، دار الكتب العلمية

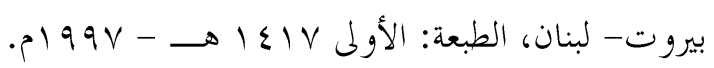

管

• - - الطبري: جامع البيان في تأويل القر آن= تفسير الطبري، تحقيق: أحمد محمد شاكر،

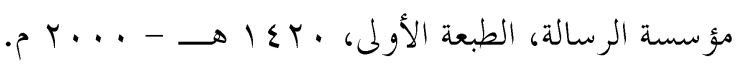

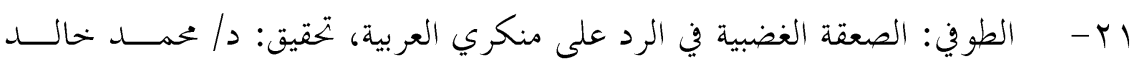

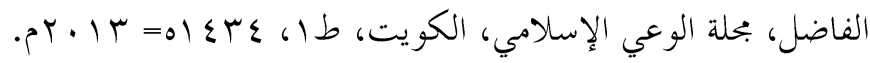

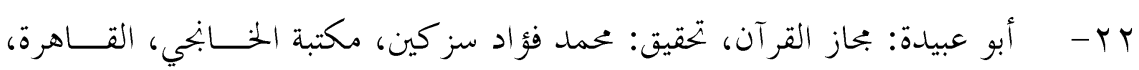

بr- - ابن العربي: أحكام القرآن، راجع أصوله وخرج أحاديثه وعلّق عليه: محمد عبد القادر عطا

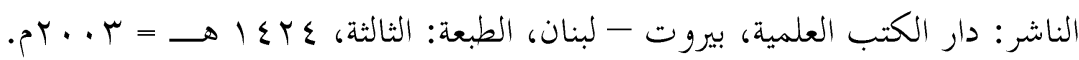
ع r- - ابن عطية: المرر الوجيز في تفسير الكتاب العزيز، عبد السلام عبد الشافي محمد،

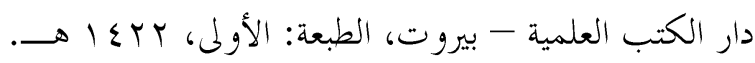

هـ- - ابن عقيل: شرح ابن عقيل على ألفية ابن مالك، محمد محيي الدين عبد الحميد، دار التراث - القاهرة، دار مصر للطباعة ، سعيد جودة السحار وشركاه، الطبعــة :

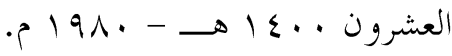

$$
\begin{aligned}
& \text { דr- }
\end{aligned}
$$

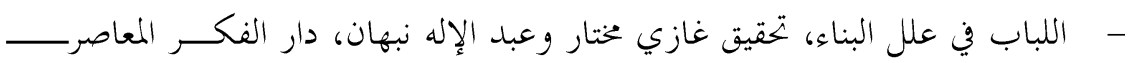

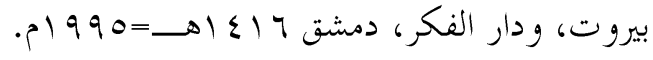




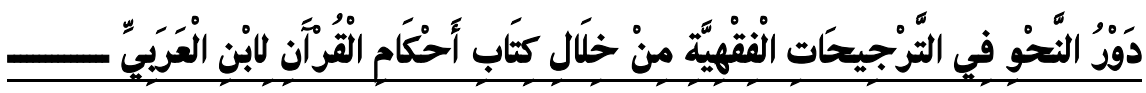

- - التبيين عن مذاهب النحويين البصريين والكوفيين، تحقيق: د/ عبدالرحمن بن سليمان

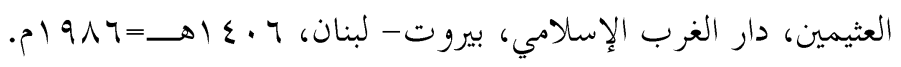

- - التبيان في إعراب القرآن، علي محمد البجاوي، الناشر: عيسى البابي الحلبي وشركاه.

rV

$$
\text { . } 199 \cdot=\text { - 1 1 } 1 \text {. }
$$

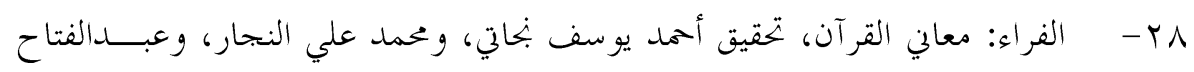

$$
\text { إسماعيل الشبي، دار المصرية للتأليف و الترجمة- مصر . }
$$

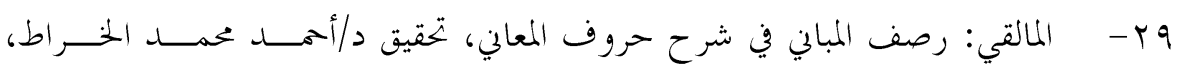
مطبوعات بحمع اللغة العربية بدمشق.

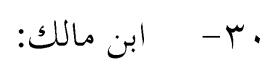

- - تسهيل الفوائد و تكميل المقاصد، تحقيق: محمد كامل بركات، دار الكتاب العــربي

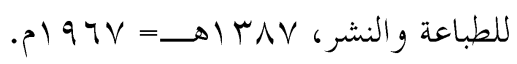

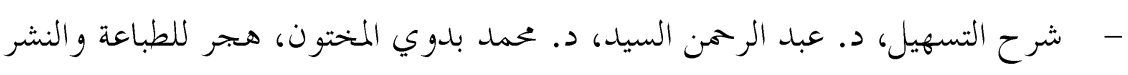

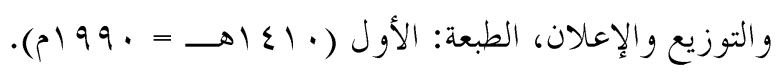

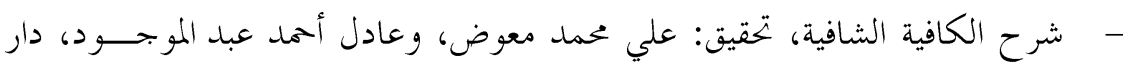

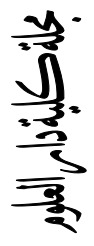

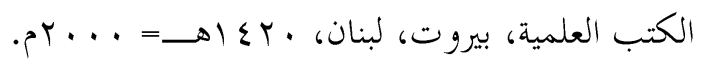

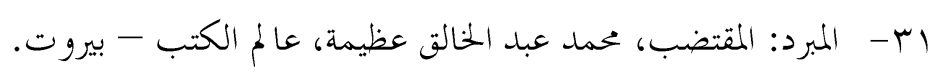

ץT- محمد علي الصابوني: روائع البيان تفسير آيات الأحكام، طبع على نفقة: حسن

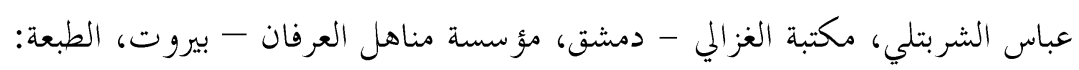

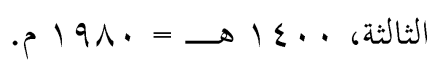

سب- محيي الدين درويش: إعراب القرآن وبيانه، دار الإرشاد للشــئون الجامعيــة-

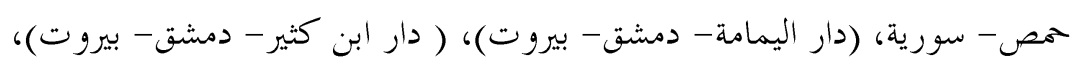

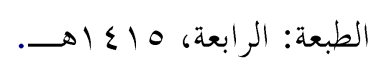

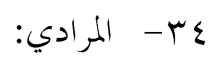

- الجنى الداني في حروف المعاني، د فخر الدين قباوة، والأستاذ محمد نديم فاضل، دار

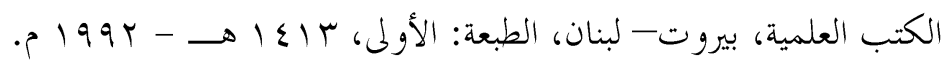




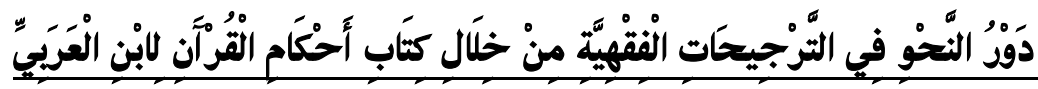

- توضيح المقاصد والمسالك بشرح ألفية ابن مالك، شرح وتتقيق د: عبد الرحمن علي

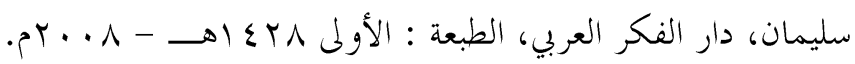

$$
\text { هـ- النحاس(أبو جعفر): }
$$

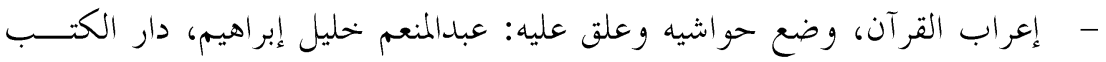

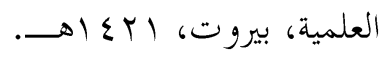

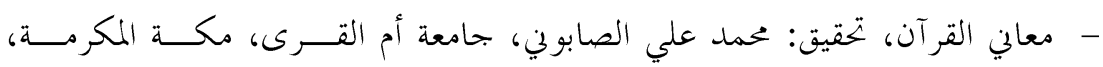
$.01 \leqslant 9$.

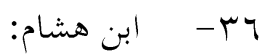

- شرح قطر الندى وبل الصدى، محمد ميى الدين عبد الحميد، القــاهرة، الطبعـة: 11)

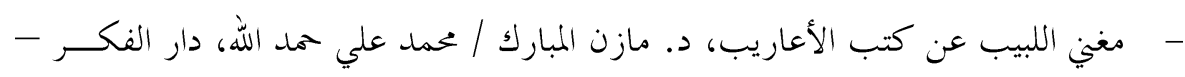
دمشق، الطبعة: السادسة، 1910.

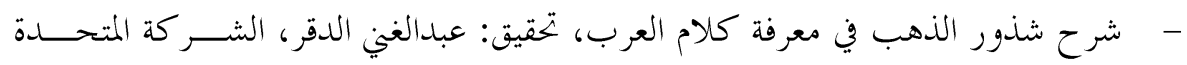

$$
\text { للتوزيع، سوريا. }
$$

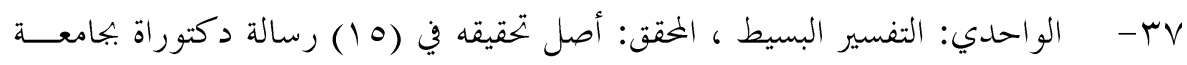

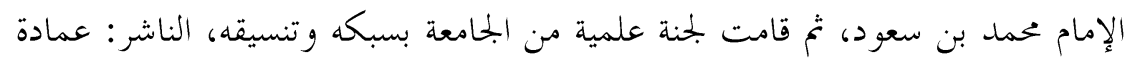

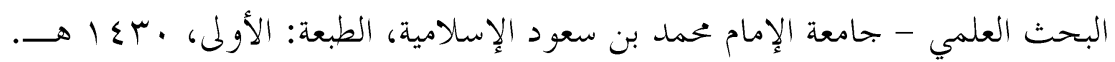

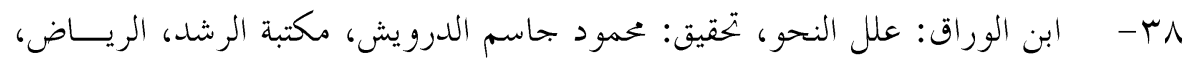
$.01999=\longrightarrow 01 \leqslant r$.

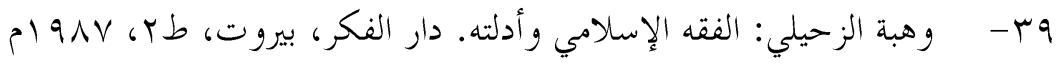

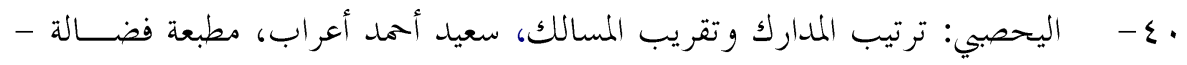

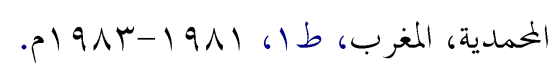

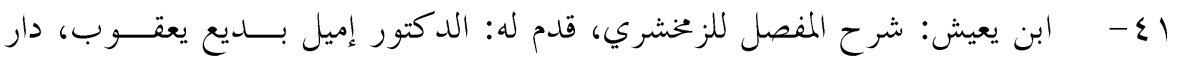

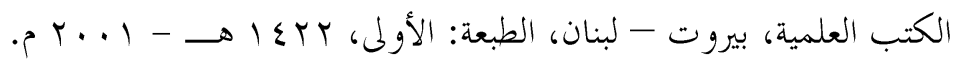




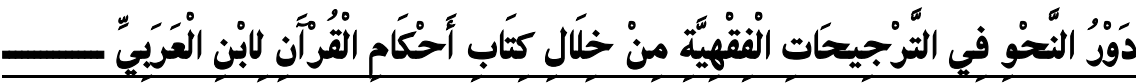

\section{الهوامش والإحالات:}

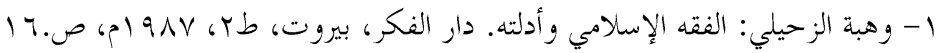

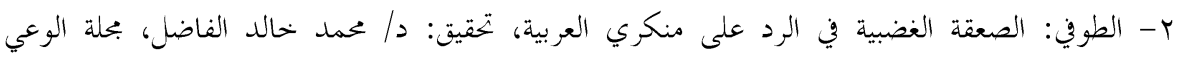

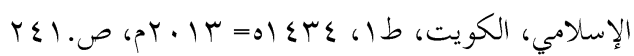

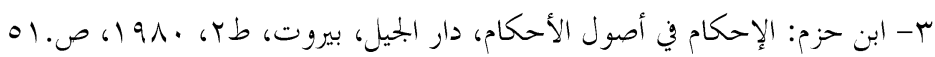

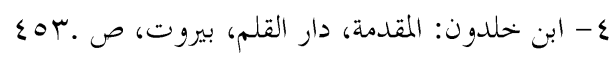

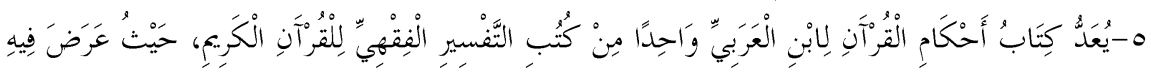

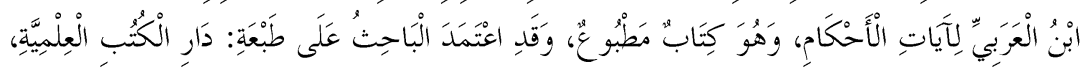

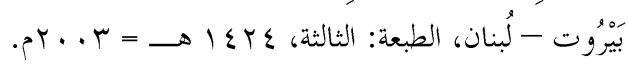

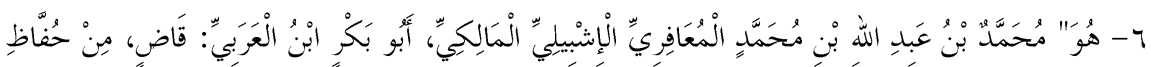

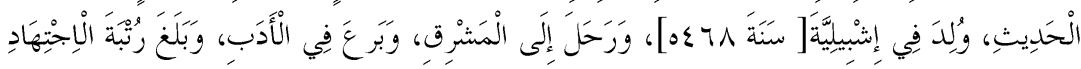

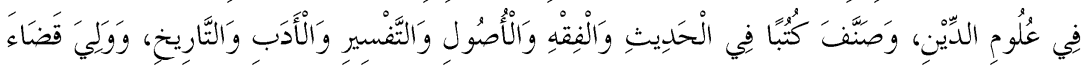

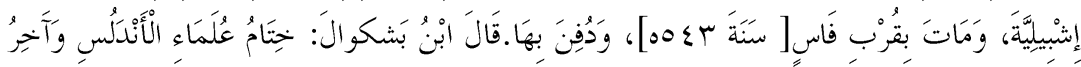

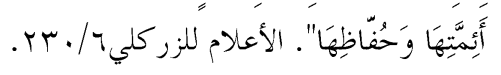

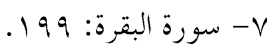

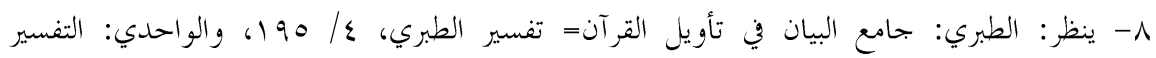

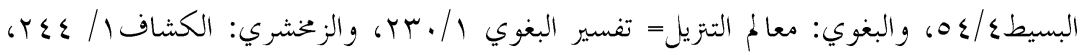

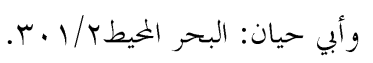

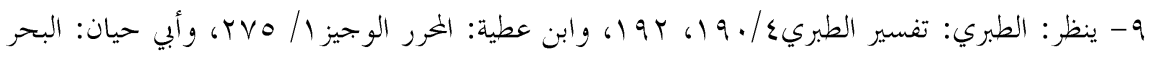

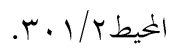

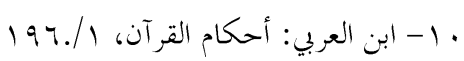

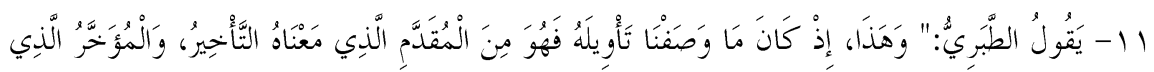

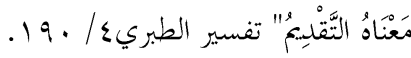

$$
\begin{aligned}
& \text { | IV. سورة البلد }
\end{aligned}
$$

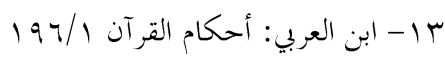

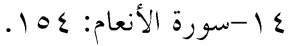

$$
\begin{aligned}
& \text { 1 - ابن العربي: أحكام القرآن، 19/1 19 1. }
\end{aligned}
$$

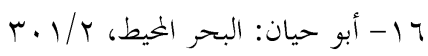

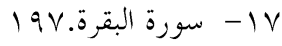

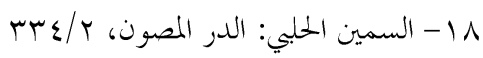

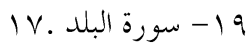




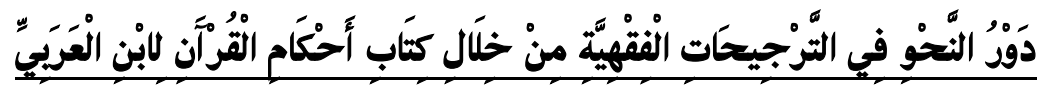

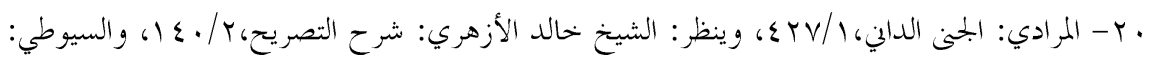

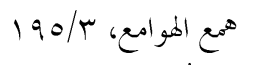

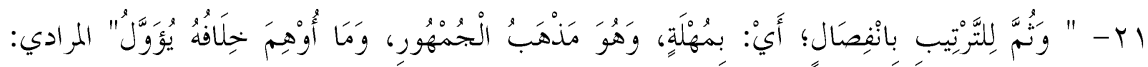

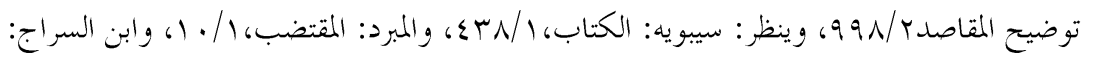

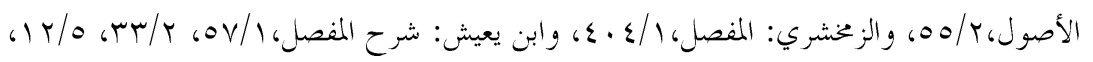

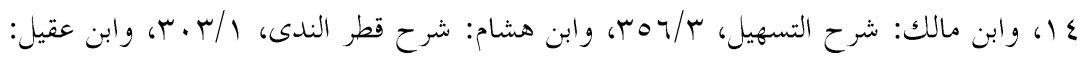

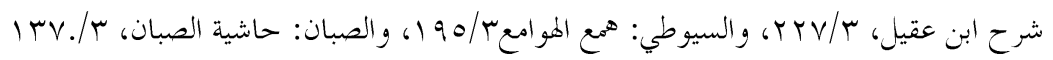

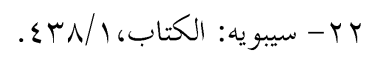

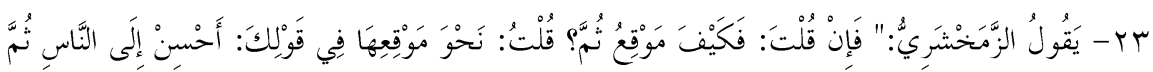

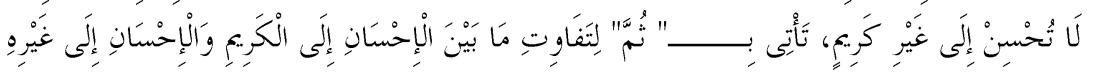

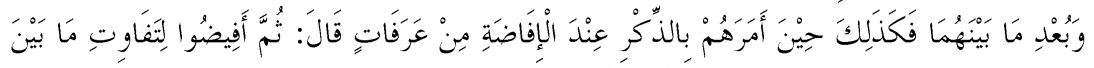

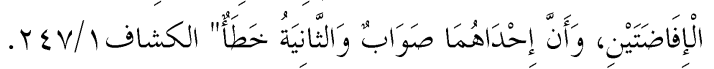

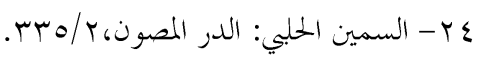

$$
\begin{aligned}
& \text { ه - السابق نفسه. }
\end{aligned}
$$

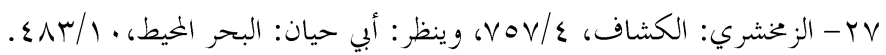

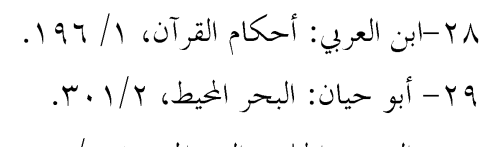

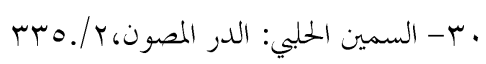

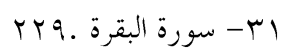

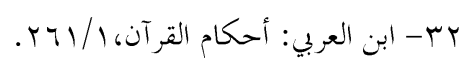

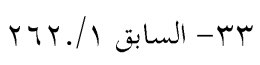
ع ع- السابق نفسه. هـ- السابق نفسه.

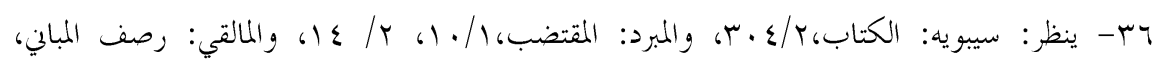

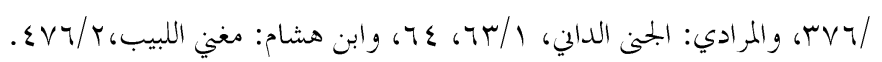

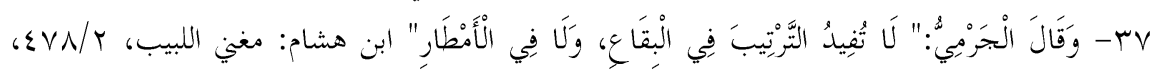

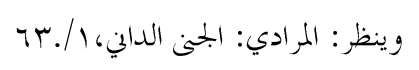

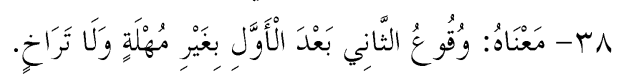

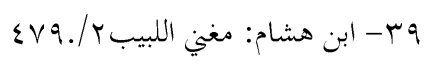




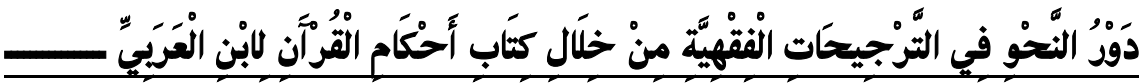

$$
\varepsilon \wedge 0 . / r \text { r } 1 \text {. } 1 \text {. }
$$

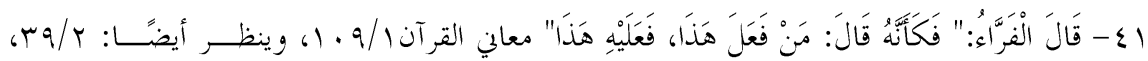

110.

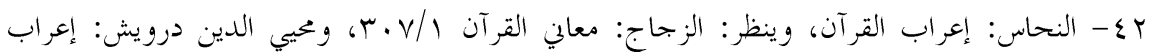

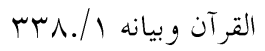

9r.

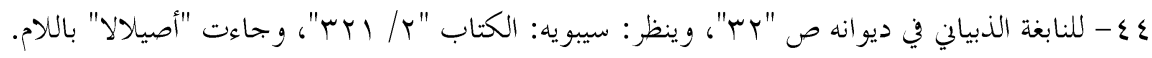

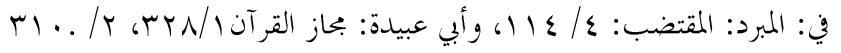

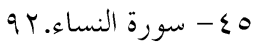

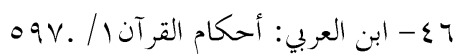

$$
\begin{aligned}
& \text { V V - السابق نفسه. }
\end{aligned}
$$

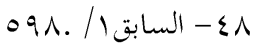

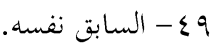

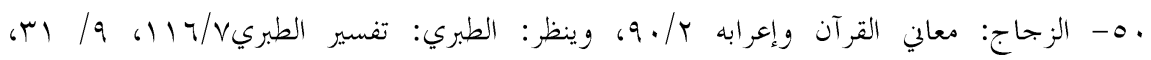

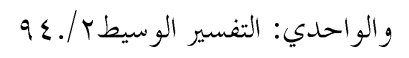

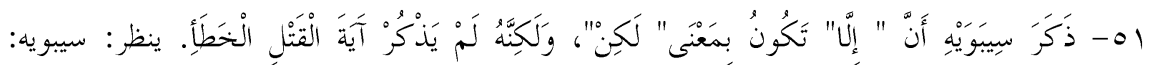

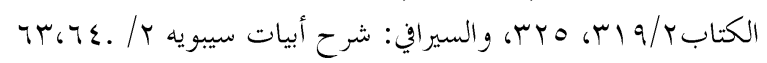

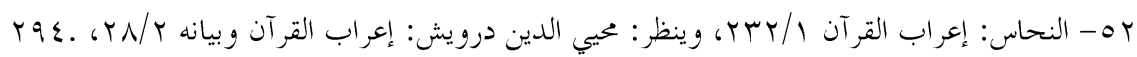

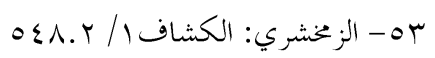$$
\text { \& }
$$

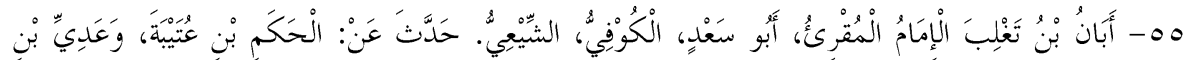

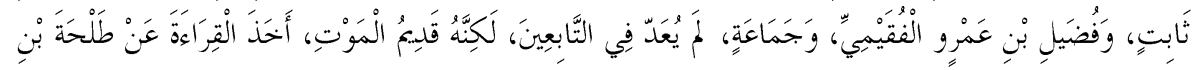

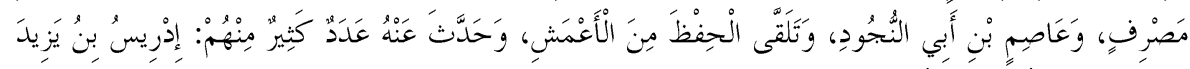

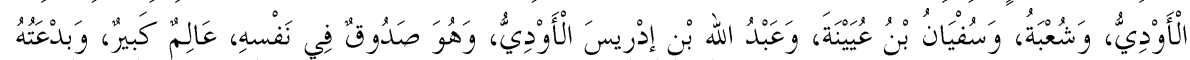

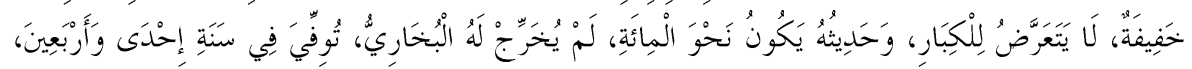

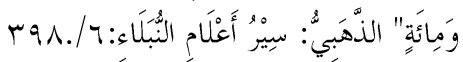

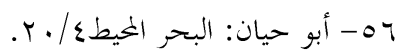
OV - السابق نفسه. 1 - مورة المائدة.

9ه - سورة المائدة.7

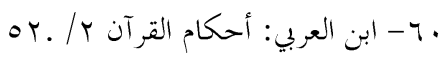




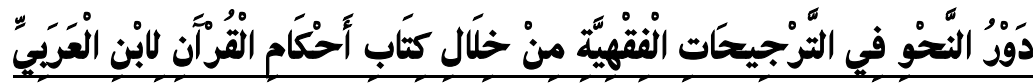

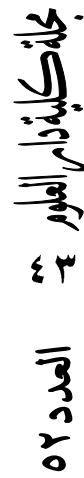

$$
\begin{aligned}
& \text { آ- - السابق نفسه. } \\
& \text { بآ- السابق نفسه. } \\
& \text { با7- السابق نفسه. }
\end{aligned}
$$

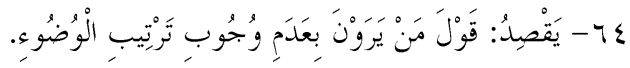

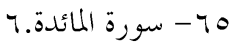

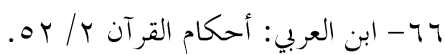

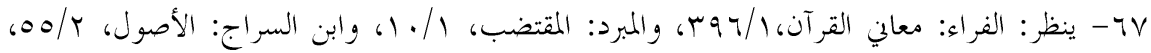

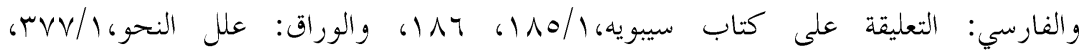

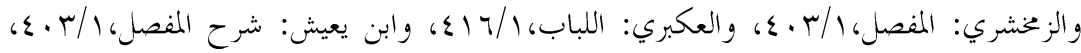

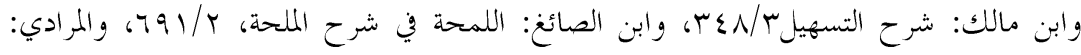

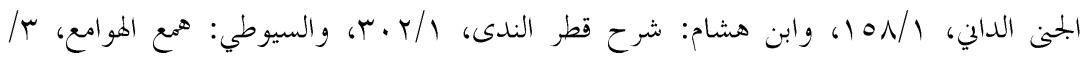

117.6110

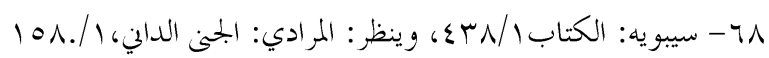

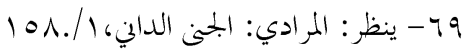

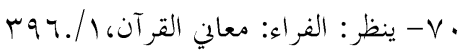

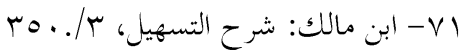
Tو -VY سو -VY ع Vورة النساء.T

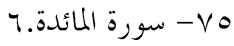
T Tو سورة المائدة.T سورة المائدة.7 -V - سورة المائدة. - V9 ^- سورة النساء.

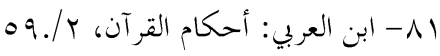

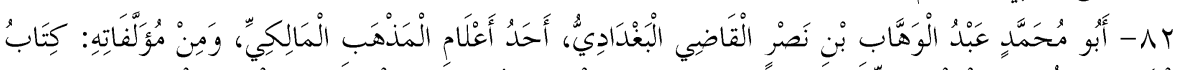

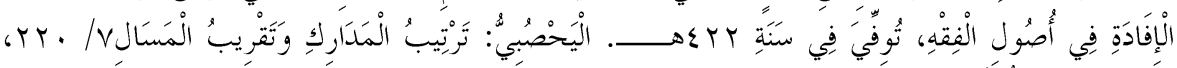

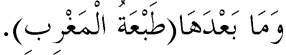

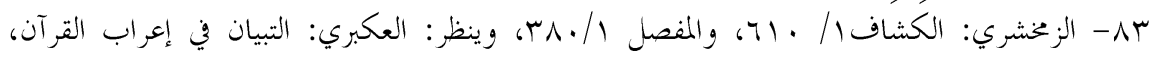

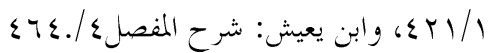

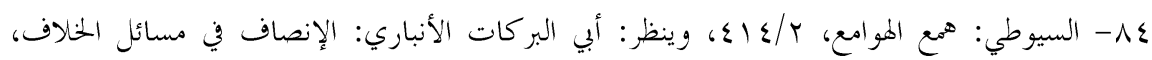
. Y I T/1

م-10 سورة آل عمران: بآن، وسورة الصف: .عا 


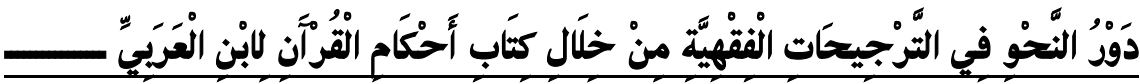

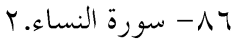

$$
\begin{aligned}
& \text { TV }
\end{aligned}
$$

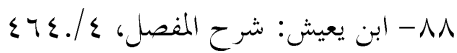

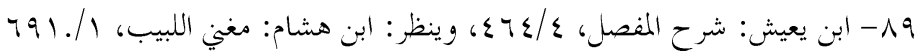

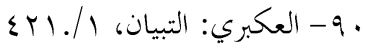

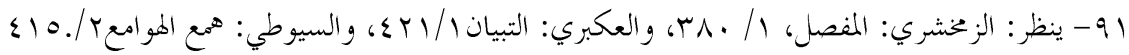

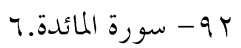

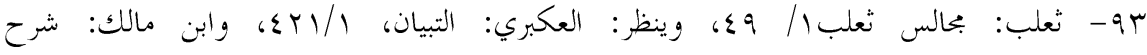

$$
17 \text { التسهيل } 17 .
$$

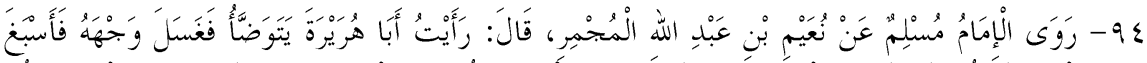

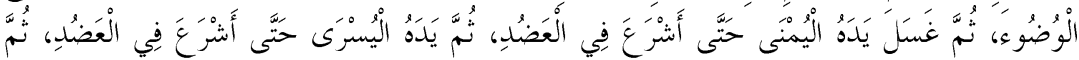

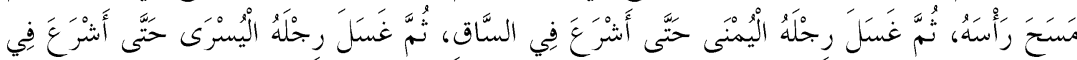

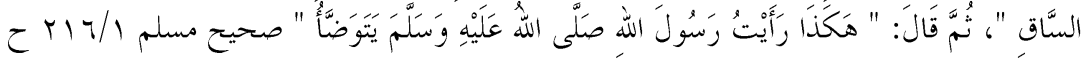

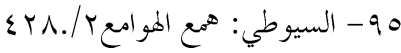

$$
\begin{aligned}
& \text { 79 - سورة المائدة.7 }
\end{aligned}
$$

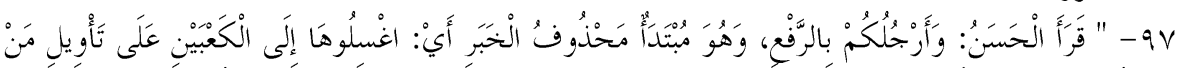

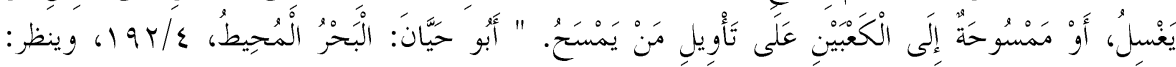

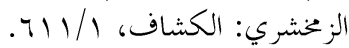

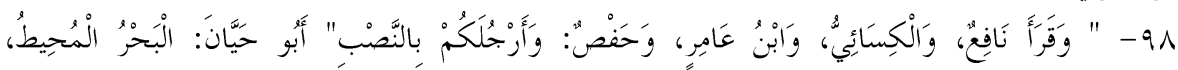

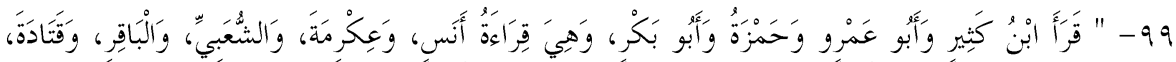

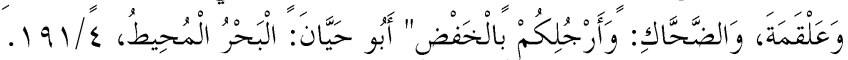

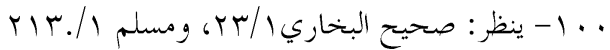

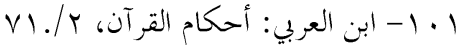

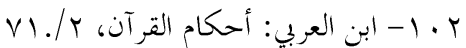

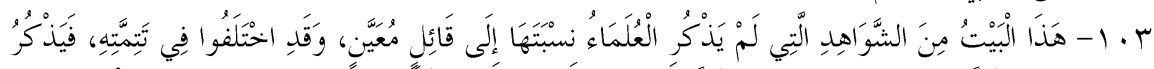

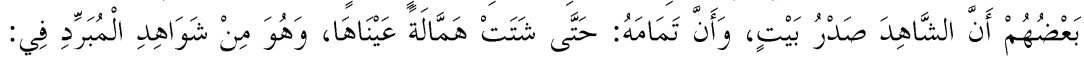

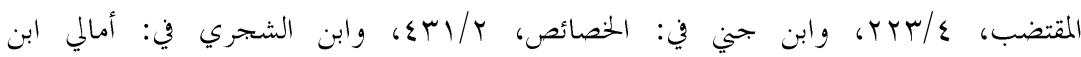

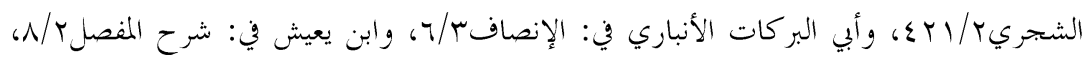

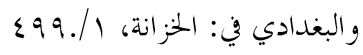

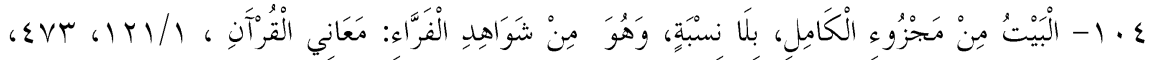

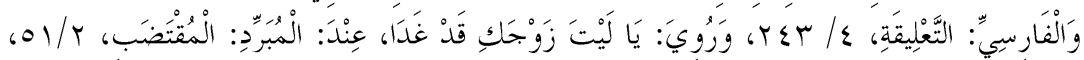

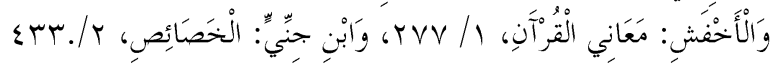




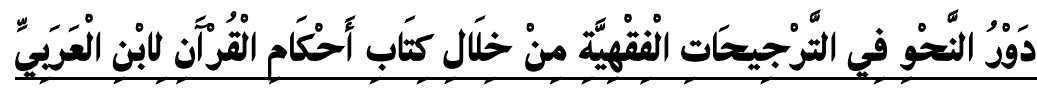

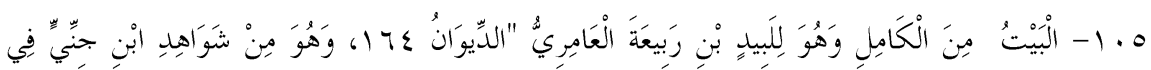

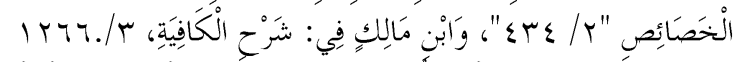

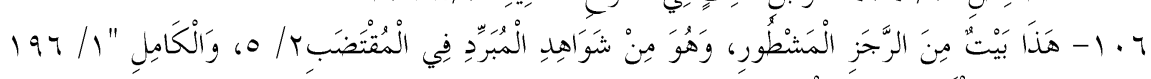

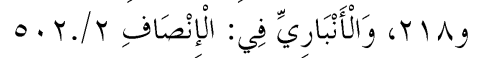

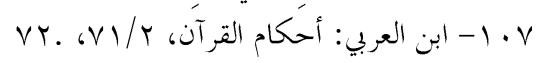

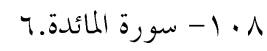

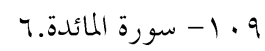

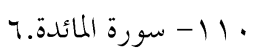

111

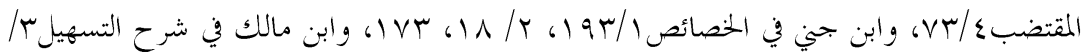

$$
r \cdot \Lambda \text {. }
$$

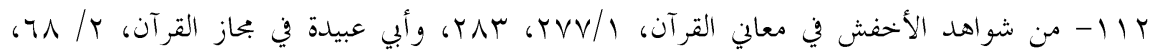

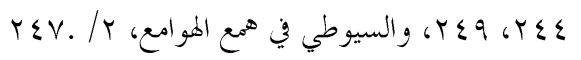

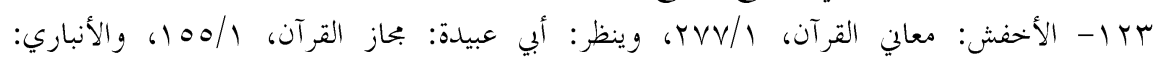

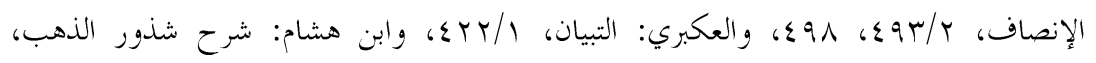

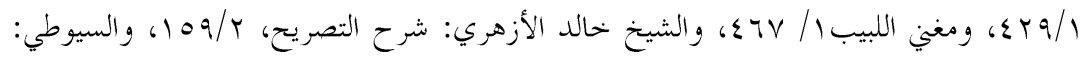

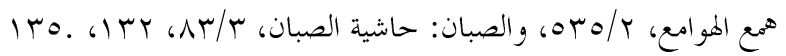

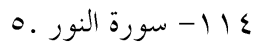

$$
\begin{aligned}
& \text { 0. }
\end{aligned}
$$

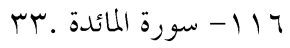

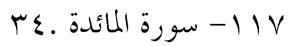

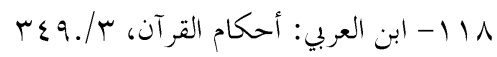

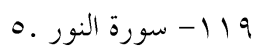

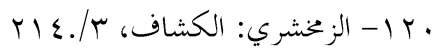

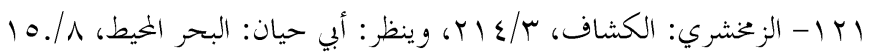

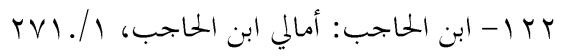

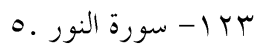

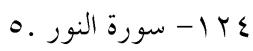

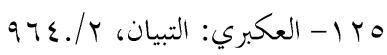

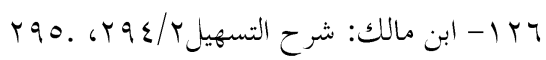

$$
\begin{aligned}
& r \mid V . / 1
\end{aligned}
$$

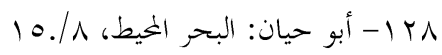

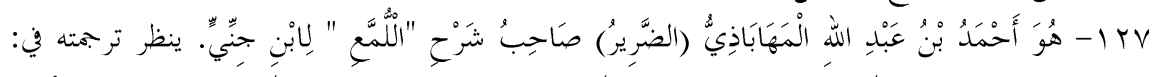

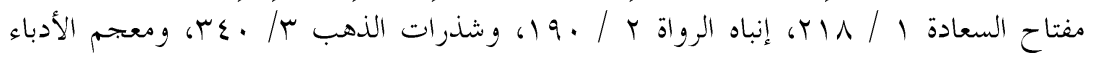




$$
\begin{aligned}
& \text { و ا 1 - السابق نفسه. }
\end{aligned}
$$

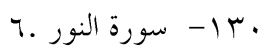

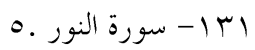

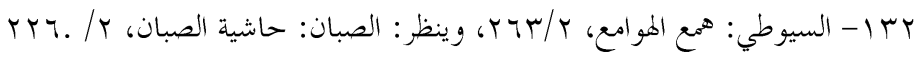

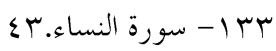

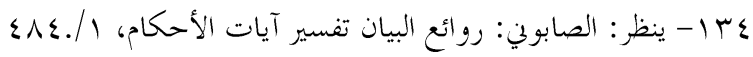
هب ا - السابق نفسه.

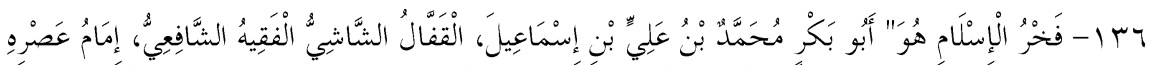

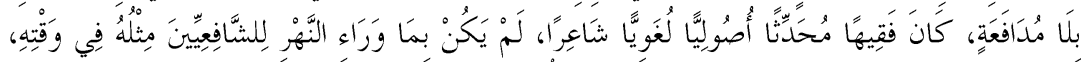

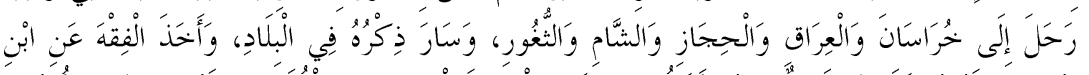

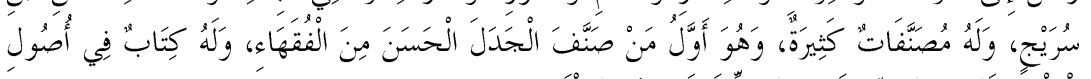

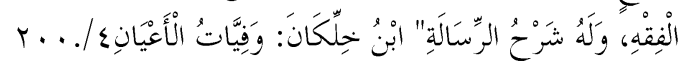

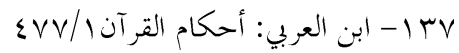

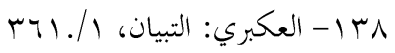

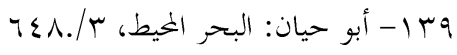

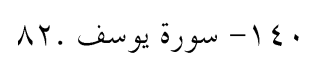

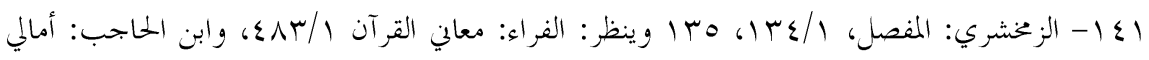

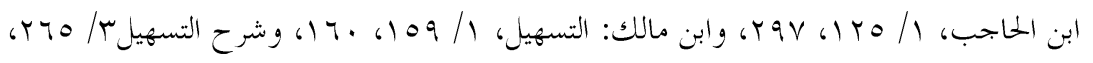

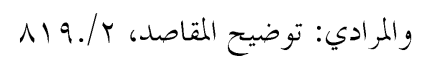

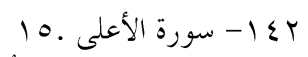

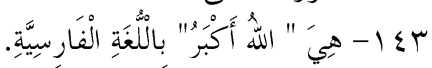

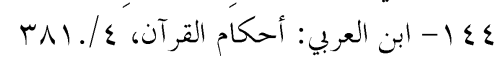

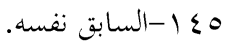

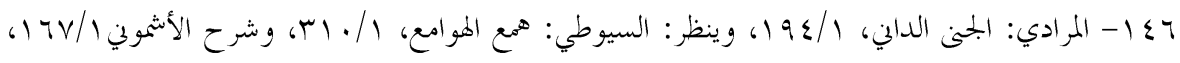

